
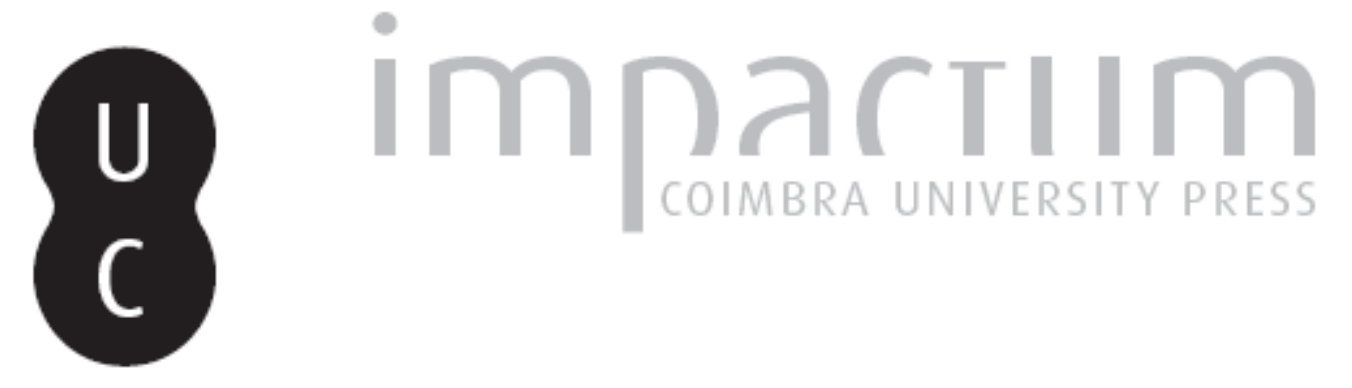

\title{
Riscos naturais na Alcobaça cisterciense
}

\section{Autor(es): $\quad$ Tavares, J. Pedro}

Publicado por: Associação Portuguesa de Riscos, Prevenção e Segurança

URL persistente:

URI:http://hdl.handle.net/10316.2/40070

DOI:

DOI:https://doi.org/10.14195/1647-7723_10_2

Accessed : $\quad$ 26-Apr-2023 15:53:37

A navegação consulta e descarregamento dos títulos inseridos nas Bibliotecas Digitais UC Digitalis, UC Pombalina e UC Impactum, pressupõem a aceitação plena e sem reservas dos Termos e Condições de Uso destas Bibliotecas Digitais, disponíveis em https://digitalis.uc.pt/pt-pt/termos.

Conforme exposto nos referidos Termos e Condições de Uso, o descarregamento de títulos de acesso restrito requer uma licença válida de autorização devendo o utilizador aceder ao(s) documento(s) a partir de um endereço de IP da instituição detentora da supramencionada licença.

Ao utilizador é apenas permitido o descarregamento para uso pessoal, pelo que o emprego do(s) título(s) descarregado(s) para outro fim, designadamente comercial, carece de autorização do respetivo autor ou editor da obra.

Na medida em que todas as obras da UC Digitalis se encontram protegidas pelo Código do Direito de Autor e Direitos Conexos e demais legislação aplicável, toda a cópia, parcial ou total, deste documento, nos casos em que é legalmente admitida, deverá conter ou fazer-se acompanhar por este aviso.

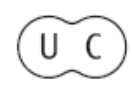




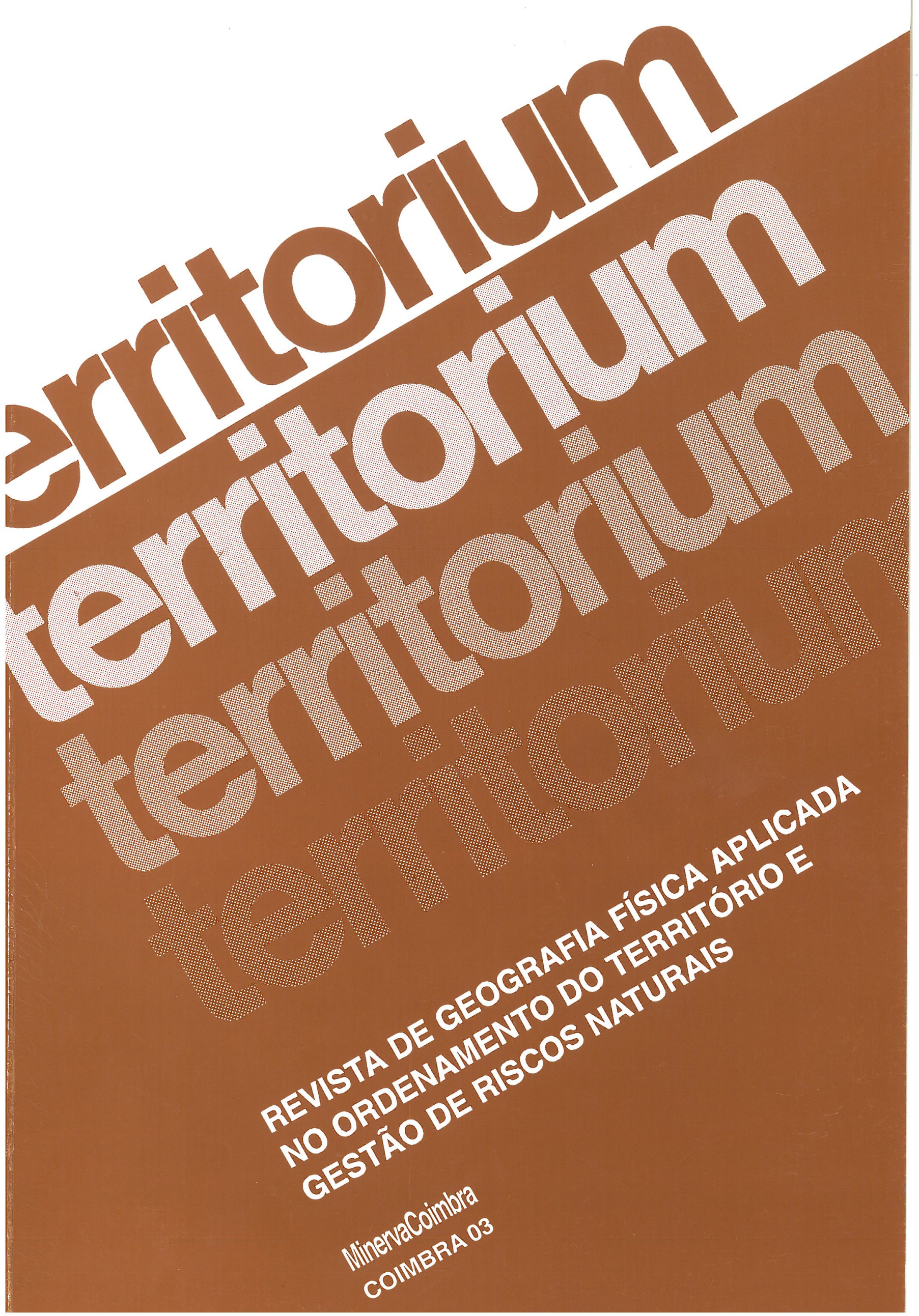




\title{
Riscos Naturais na Alcobaça Cisterciense
}

\author{
J. Pedro Tavares*
}

\section{Resumo:}

Alcobaça torna-se num exemplo interessante de constatação histórica de efeitos de Riscos Naturais. Trata-se não só de um dos mais importantes e bem conservados Conjuntos Monásticos Cistercienses, com a sua memória, mas também de um dos mais sensíveis aos efeitos das cheias seculares. O Conjunto Monumental edificado, nascido há 850 anos e sempre em mutação, encerra registos e marcas desses efeitos, por vezes assinalando catástrofes de monta. Os legados dos "Historiógrafos de Alcobaça", os escritos deixados por vultos notáveis da Alcobaça secular sucedânea dos Monges, bem como estudos da epopeia universal cisterciense, quando analisados em espírito de observação técnica e de cruzamento pluridisciplinar, ajudam à interpretação deste modelo quase que milenar, mas sempre evolutivo.

Palavras chave:

Riscos Naturais, Cheias, Assentamentos Diferenciais, Mosteiro Cisterciense, Hidráulica Monástica, Alcobaça

\section{Résumé:}

Alcobaça devient un exemple intéressant de constatation historique des effets des Risques Naturels. Il s'agit non seulement d'un des plus importants et mieux conservés des Ensembles Monastiques Cisterciens édifiés, avec sa mémoire. mais aussi un des plus sensibles aux effets des crues séculaires. L'Abbaye Monumentale, née il y a 850 années et toujours en mutation, garde en soi les enregistrements et les marques de ces effets, parfois signalant des catastrophes importantes. Les écrits laissés par les "Historiographes d'Alcobaça" et par des personnages notables de l'Alcobaça séculier qui suivit l'époque des Moines, aussi que les études publiées sur l'Epopée Universelle Cistercienne, aident à l' interprétation de ce modèle presque millénaire, mais toujours en évolution. Il faut portant les analyser en esprit d'observation technique et d'entrecroisement pluridisciplinaire.

Mots clés:

Risques Naturels, Crues, Tassement du sol, Monastère Cistercien, Hydraulique Monastique, Alcobaça

\section{Abstract:}

Alcobaça is an interesting example of the historical evidence for Natural Risks. The Monastic Ensemble, with its own memory, is one of the most important and best kept of the Cistercian world, as well as one of the most open to the effects of flooding. The Monumental Abbey was born 850 years ago and retains evidence and marks of these effects, sometimes revealing remarkable catastrophes. The legacy of the "Alcobaça Historians". followed by the writings of notable personalities of the secular Alcobaça, as well as studies of the universal Cistercian Entreprise, all help in the understanding of this almost millennial but evolving model. This requires an analysis combining technical observation with a multidisciplinary approach.

Key words:

Natural Risks, Floods, Soil Settlement, Cistercian Monastery, Monastic Hydraulics, Alcobaça

\section{Breve Introdução à Ordem Cisterciense e à Água}

Um Mosteiro Cisterciense, na sua origem, seria um conjunto edificado completo, num programa preciso de funções e de espaços, contido numa "cerca" com horta e terras de cultivo, o moinho, as oficinas e tudo o mais necessário à vida de uma Comunidade fechada ao exterior. O Modelo Cisterciense era estratificado nas suas Classes (Abade, Monges Brancos, Irmãos Conversos, Noviços, ...) nos seus Espaços de rígida implantação (para serviço das variadas Funções e Classes, quer construidos, quer na Cerca) e também nas Águas (rios, levadas, condutas, cada um com as suas finalidades específicas). A relação entre Abadias

\footnotetext{
* Engenheiro Consultor, ligado ao Planeamento e Coordenaçāo de Projectos e Estudioso do "Génio Civil" Cisterciense
}

processava-se numa cascata de fundações/filiações que veio a cobrir todo o mundo conhecido de então, num crescimento exponencial que teve o seu auge quando Bernard de Clairvaux assumiu o Abaciato-Geral da Ordem, liderança que culminou em 1153. ano da última fundação da sua lavra de mais de trezentas e que foi precisamente a de Alcobaça.

Como na maioria dos Mosteiros Cistercienses, uma poderosa organização aliada a um pragmatismo e a uma clarividente acção administrativa, levou Alcobaça a tornar-se na maior "máquina económica" do seu tempo em Portugal, o que the grangeou poder, prestígio e certamente um modo de vida diferente do das origens. Longa foi a evolução histórica, organizacional e espacial, mas sempre como Mosteiro e o seu Abade como pontos centrais e a Água como elemento imprescindível ao seu funcionamento. 


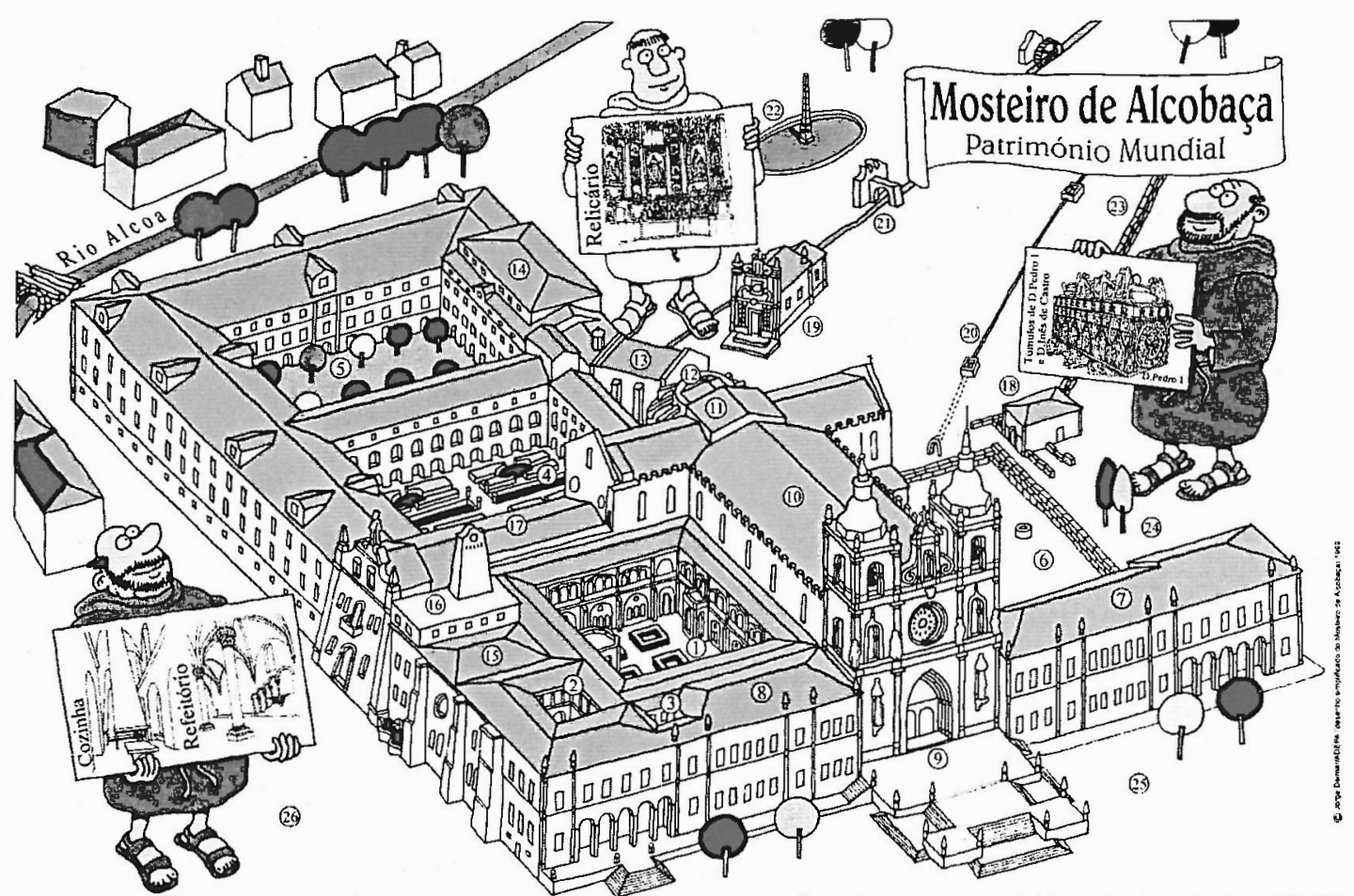

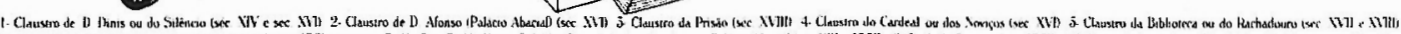

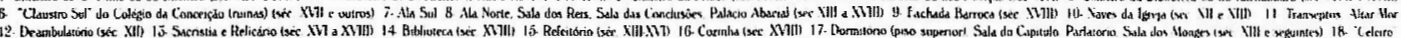

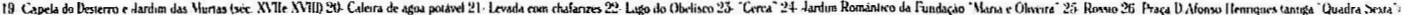

Foto 1 - Desenho Perspectivado Esquemática do Conjunto Monumental do Mosteiro de Alcobaça (P.TAVARES, J.DELMAR, 1999).

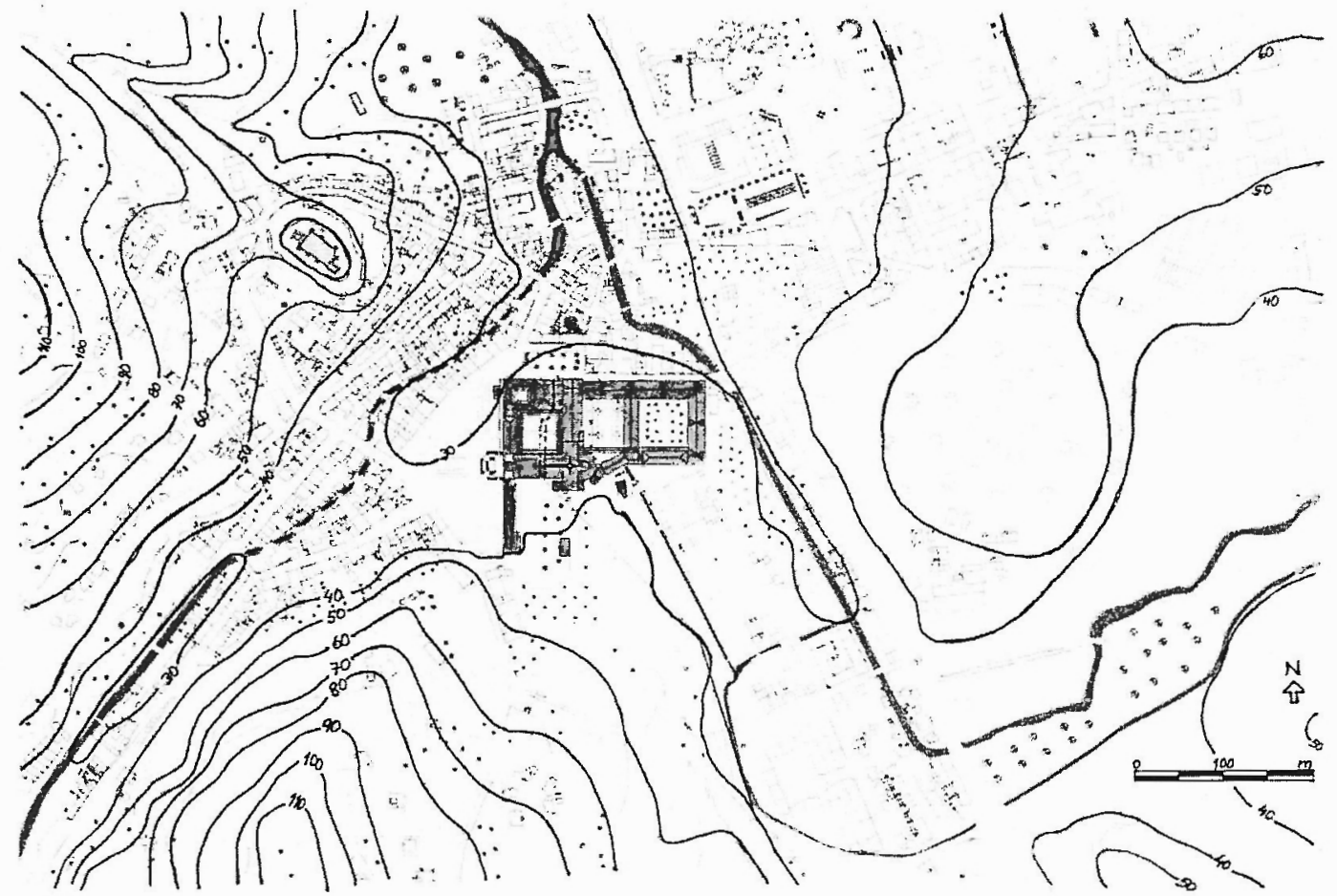

Foto 2 - Planta de Alcobaça 2000, com o Mosteiro, as linhas de água e as curvas de nível realçadas (P.TAVARES, 2001), sobre base digital da C.M.Alcobaça. 


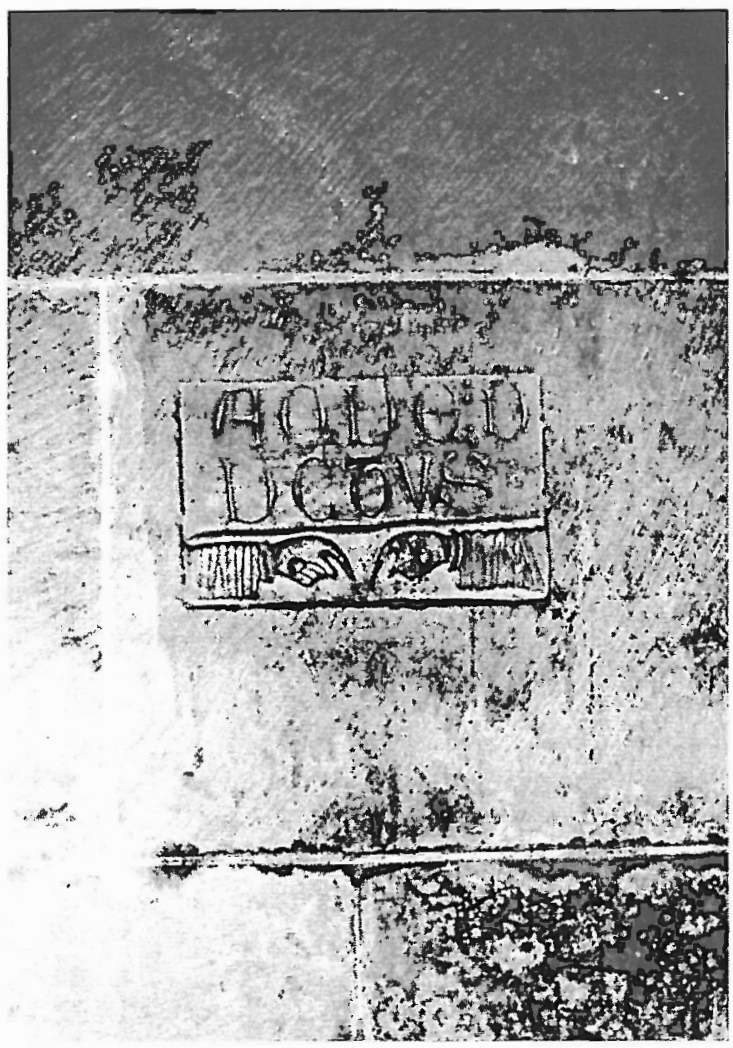

Foto 3 - Expressivo "guardião técnico" no Alçado interior da Nave Colateral Norte, assinaiando o local de passagem de duas condutas de alimentação de Água Potável do Lavabo e da Cozinha (P.TAVARES, 1999).

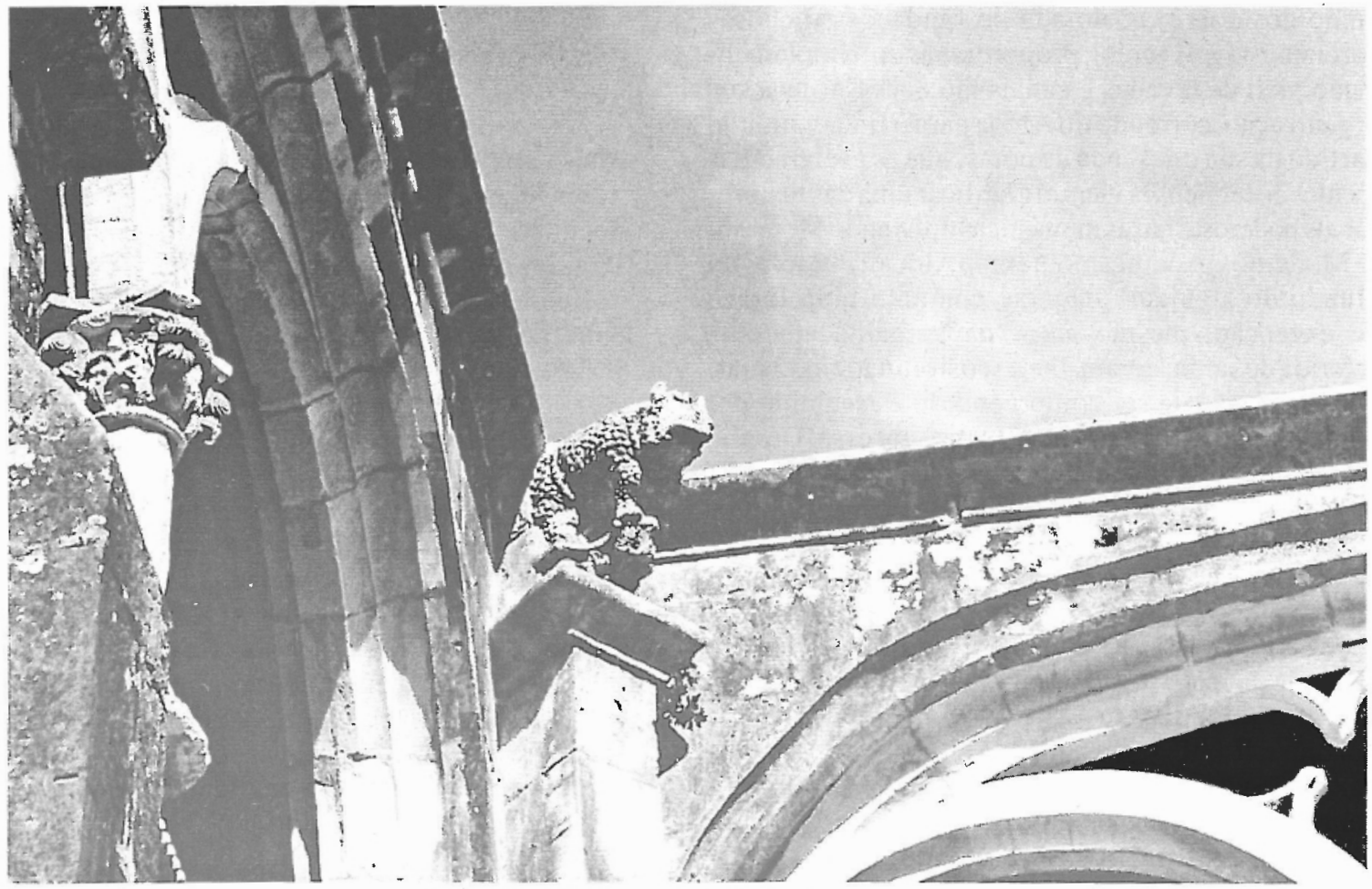

Foto 4 - Gárgula do Rinoceronte. no canto Norte-Poente do Sobreclaustro do Silêncio, imortalizando o primeiro exemplar trazido para a Europa. Existe outro registo pétreo sob a forma de uma mísula, na Torre de Belém em Lisboa, deste célebre animal que também causou a admiração de Reis, sucumbiu por naufrágio a caminho do Papa, foi embalsamado e foi ainda alvo de desenho pela pena de Dürer (P.TAVARES, 1999). 
Nos tempos iniciais e de clausura, se o ar tudo enche, a luz vem do Sol diário e a terra e a pedra já lá estão, foi a água o elo mais marcante de ligação permanente ao exterior. Mais tarde, já na fase de domínio e poder económico, administrativo também político, a mestria da água e o controlo da tecnologia inerente ajudaram a marcar a diferença.

O Mosteiro de Alcobaça foi fundado, segundo uma lenda adaptada às conveniências da História, numa pequena plataforma alúvio-sedimentar criada na confluência de duas linhas de água, os Rios Alcoa e Baça. O Alcoa nasce de várias fontes, com ramos meandrizantes e encaixados em vales estreitos e profundos de rara beleza, buscando origens insondáveis no Maciço Calcário Estremenho (Serras d'Aire e de Candeeiros). O Baça, mais pequeno e convencional, corre para o rio irmão em direcção diametralmente oposta. Ambos rodam de cerca de $90^{\circ}$ e se abraçam a jusante do Mosteiro, atravessam a garganta da Fervença, irrigam os vastos Campos do Valado (anteriormente braço de mar, depois pântanos, depois férteis campos de cultivo) e, juntando-se aos Rio da Areia e ao Rio do Meio, atravessam a terceira barreira natural paralela ao mar na Ponte das Barcas e desaguam no areal moderno entre a Nazaré e S.Gião, templo visigótico do mais antigo cristão de que há registo em Portugal.

Foi na referida pequena plataforma aluvionar na união dos dois rios, dotada de fundações rochosas parciais estáveis (grés), proporcionando a implementação fácil de levadas e canais tão necessários à sua organização, correndo do Alcoa para o Baça e tirando partido da sua diferença de cotas, que as esclarecidas mentes cistercienses vieram a edificar uma das maiores e mais poderosas casas monásticas do Mundo Medieval e Moderno. Ao mesmo tempo, localizando-a no "fundo do alguidar" daquele conjunto hidrológico de excepção, mesmo antes da garganta apertada referida de saída, deram-lhe a sensibilidade às cheias. Desafio digno de ser compreendido e assumido por uma comunidade cisterciense, mas só por essa! Desafio que levou essa comunidade cisterciense a re-implantar os rios, a modificar-lhes profundamente os traçados e a adaptá-los às suas conveniências.

Em Alcobaça e ao longo dos séculos, enquanto a Ordem crescia aos solavancos e se autonomizava, as acções construtivas também se multiplicavam e o controle da Água desdobrava-se num sem número de funções, finalidades e sistemas, em meio urbano e em meio rural, em esquemas que hoje fariam a admiração dos mais ousados programas dos fundos comunitários da especialidade. Na altura de maior expansão construtiva do "Conjunto Monumental" no Séc. XVIII, é possível que a área de implantação edificada fosse da ordem de grandeza de $42000 \mathrm{~m}^{2}$ e que a Área Bruta Coberta Total, somatório das áreas brutas construidas em cada piso, fosse da ordem de cerca de $70000 \mathrm{~m}^{2}$. As expressões hidráulicas, essas, cobriam praticamente todo o território possível dos Coutos.

O nascimento de Alcobaça-urbe também foi singular, já que as Comunidades Cistercienses não desejavam tal vizinhança secular. Mas foi essa população laica que veio a proporcionar, por mais de um século após a fuga Cisterciense em 1833, os herdeiros locais para a re-utilização desse património gigantesco e da sabedoria das tecnologias hidráulicas.

Hoje, infelizmente, já pouco Alcobaça tem a ver quer com o seu Mosteiro, quer com a sua Hidráulica. O Mosteiro, tornado "Real" de há muito, já desde D. João I, regressou unificado ao poder Comendatário central. Quanto às riquezas hidráulicas, que tanto saber, prestígio e singularidade trouxeram a Alcobaça, estã hoje esquecidas e agonizantes face ao avanço urbano e tecnológico. A Água tornou-se num meio controlável e manipulável. Capta-se onde a há, transporta-se para onde é precisa, eleva-se às cotas necessárias, pressuriza-se em conveniência, armazenase em volume, transvasa-se em extensão.

Porém, esse aparente controlo da Natureza é meramente ilusório. E, em Alcobaça, como se não bastassem já os extremos criados por ser zona de Clima Mediterrâneo (ver F. REBELO, 2001).

\section{As catástrofes em Alcobaça e as Cheias}

$\mathrm{Na}$ vida Cisterciense, as catástrofes de ordem física e patrimonial podem ter tido origem em Cheias (com Inundações, Depósitos Sedimentares e Assentamentos), Deslizamento e Instabilidade de vertentes, Terramotos, Incêndios, Raios e faíscas, Ventos, Pestes e Epidemias, Secas e Fomes, Poluição e, também, Guerras, Revoluções, desordens ou ocupações.

Nem tudo se enquadra numa definição restrita de "Risco Natural", mas as fronteiras são por vezes bem ténues, pelo que se opta por uma relação mais abrangente.

Em Alcobaça, há registo e/ou marcas palpáveis ou subtis de quase todas as catástrofes referidas.

Mas as Cheias, acompanhadas de inundações, assoreamentos e depósitos, entupimentos, assentamentos, destruições e ruina, foram talvez a causa natural que mais perturbações criou na vida Monástica de quase sete séculos em Alcobaça, fruto de uma hidrografia/orografia peculiares, dos efeitos dos Climas Mediterrâneos e da necessidade Cisterciense de edificação em solo manuseável de forma útil, de modo a pôr a água ao serviço da comunidade abacial.

O Ciclo da Água sente-se em Alcobaça de outras maneiras. Foi a riqueza da água que tentou a localização dos Cistercienses no séc. XII e foi a sensibilidade 


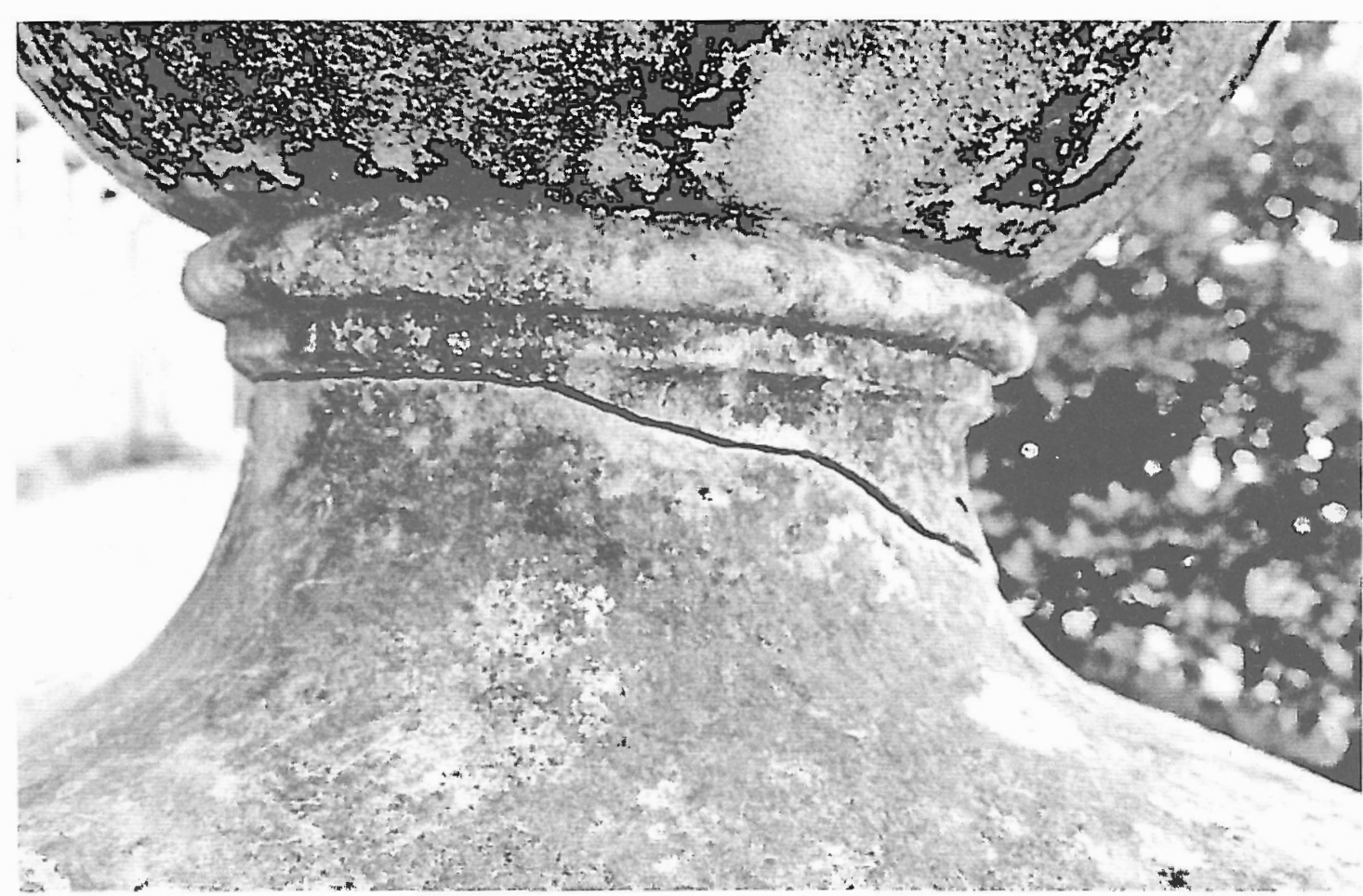

Foto 5 - Até os Mosteiros Cistercienses podem ter equilíbrios instáveis! - Bola pétrea no parterre fronteiro à Ala Norte do Mosteiro (P.TAVARES, 1999).

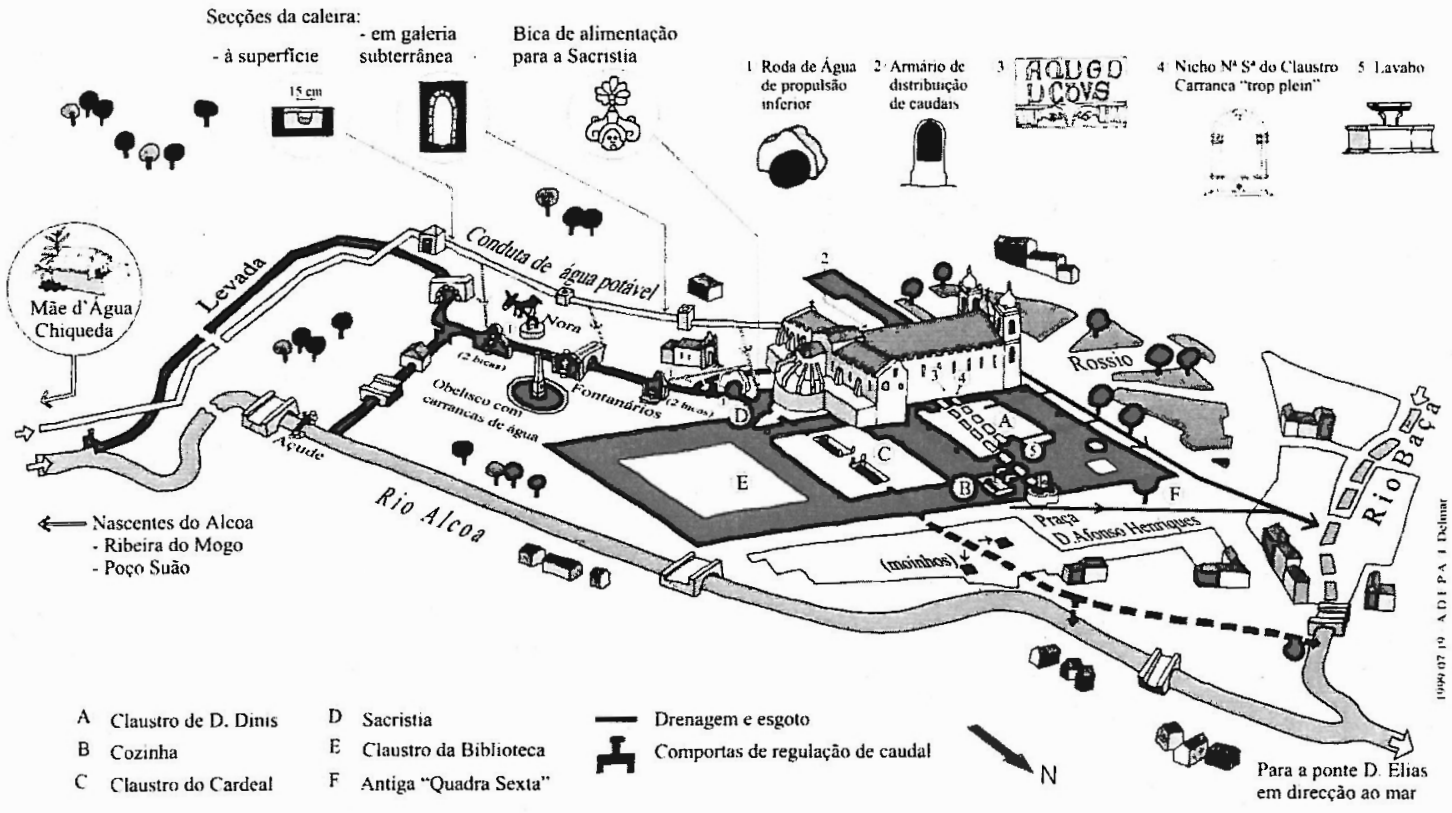

Foto 6 - Representação Esquemática do Sistema Hidráulico Cisterciense adjacente ao Mosteiro de Alcobaça. ADEPA (P.TA VARES, J.DELMAR, 1999). 


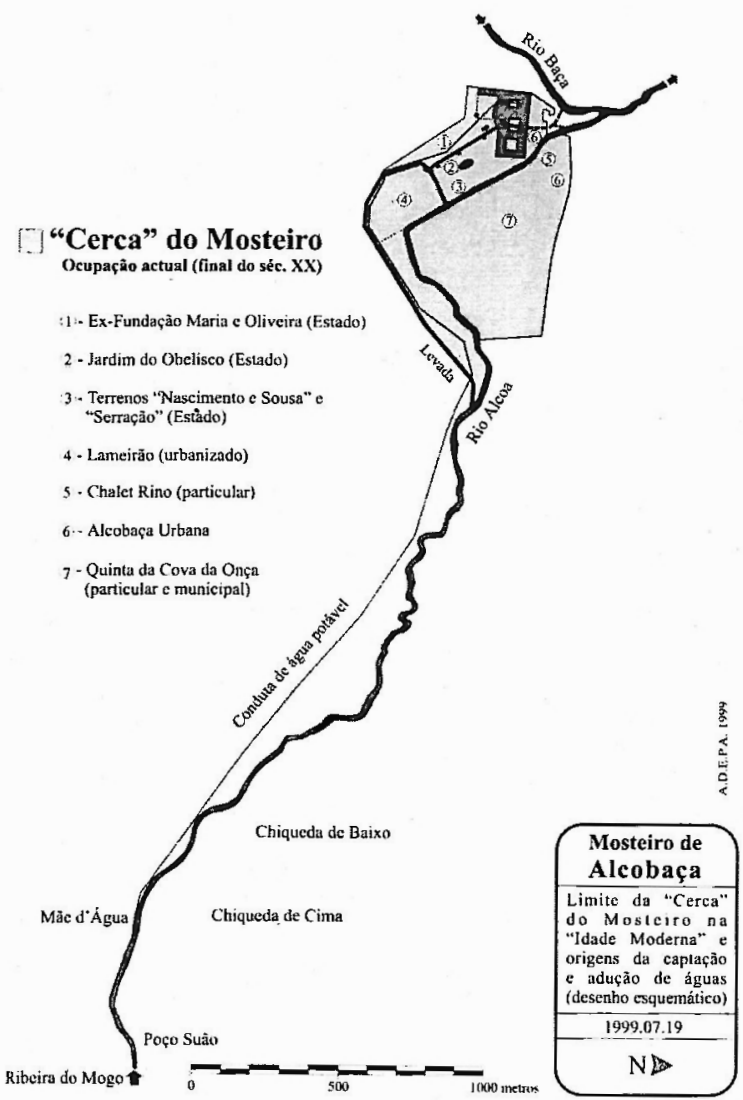

Foto 7 - Representação Esquemática da

Cerca do Mosteiro de Alcobaça na Idade Moderna, com a utilização actual.

Indicação das origens da captação e adução de Águas (3 níveis). ADEPA (P.TAVARES, J.DELMAR, 1999).

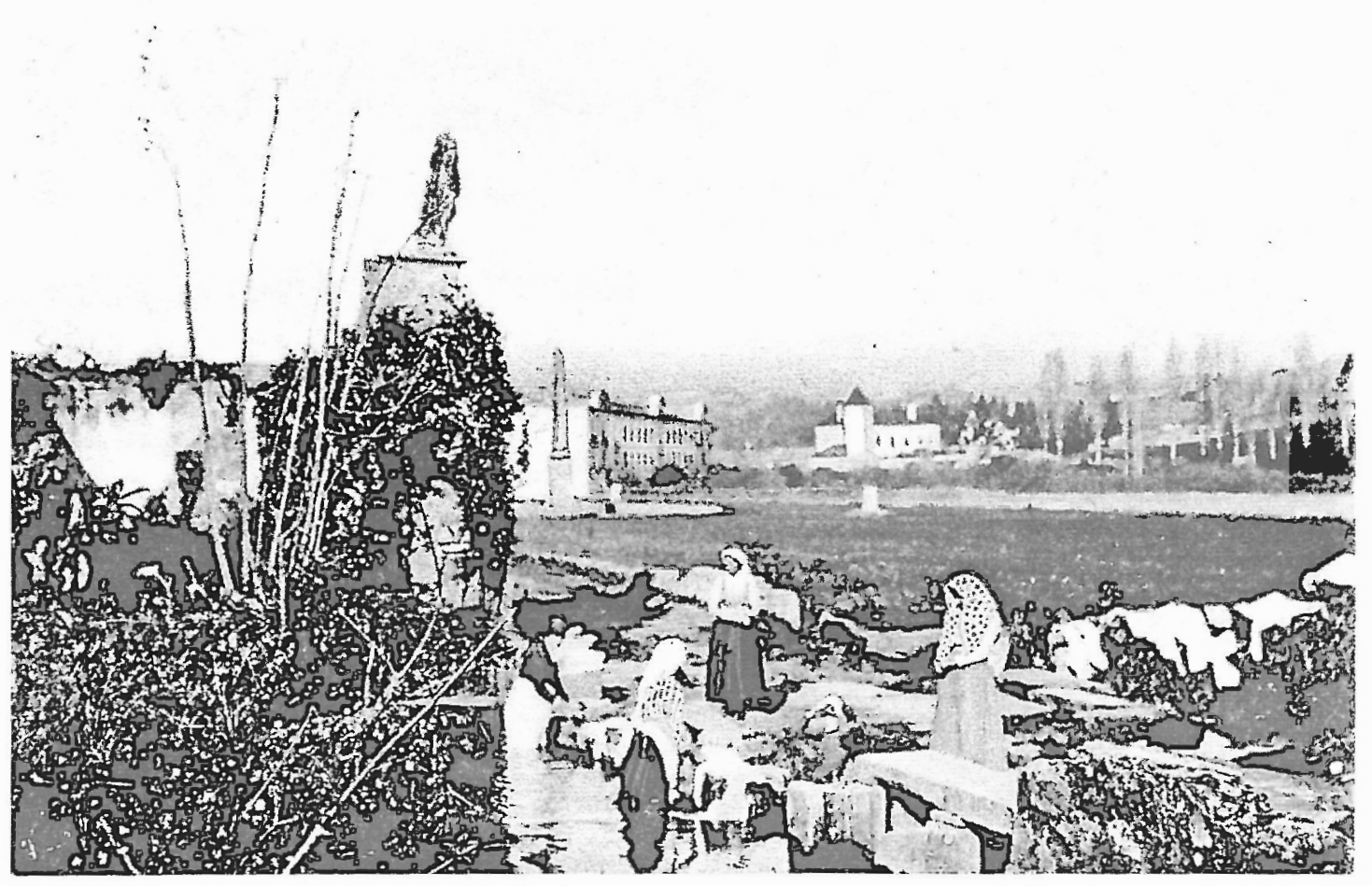

Foto 8 - A "Cerca" no início do século XX, com as Lavadeiras frente ao Fontanário 2, o Obelisco desimpedido, o Alçado Nascente do Claustro do Rachadouro e o Chalet Rino, enfim a vista de parte da plataforma aluvionar. Postal colorido. 


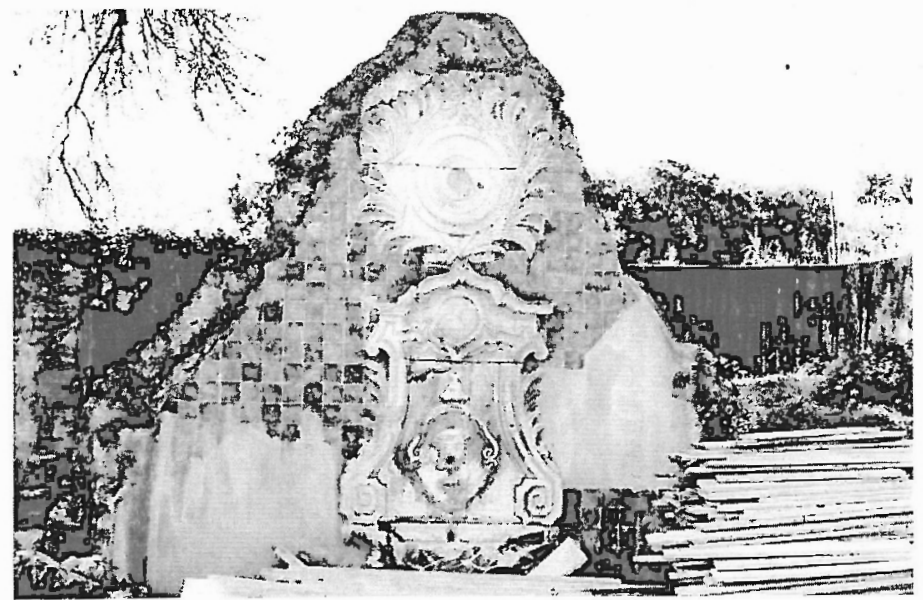

Foto 9 - Fontanário 2 da "Cerca", de duas origens de água (P.TAVARES, 1999).

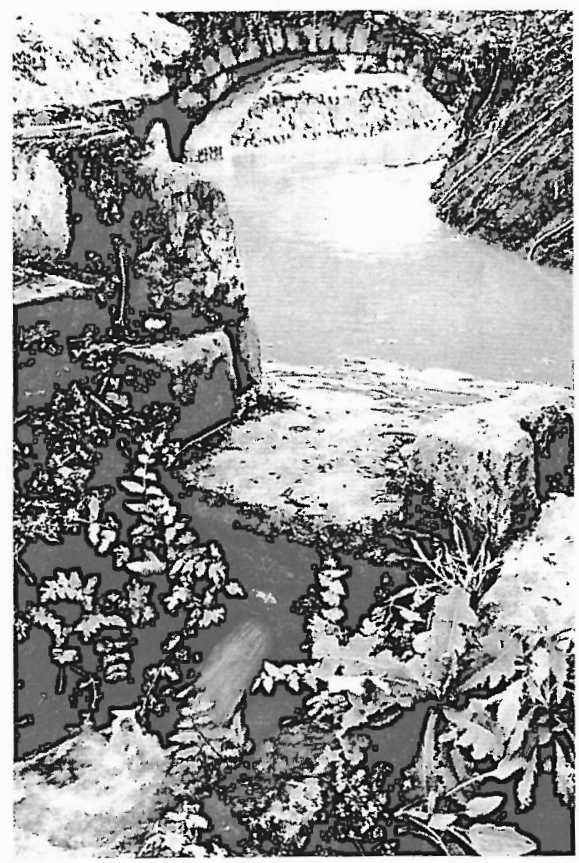

Foto 11 - Levada no "Lameirão", com arco em pedra correspondendo a um muro de "sub-cerca" (P.TAVARES, 1999).
Foto 10 - Fontanário $3 \mathrm{da}$ "Cerca", de uma origem de água, potável (P.TAVARES, 1999).

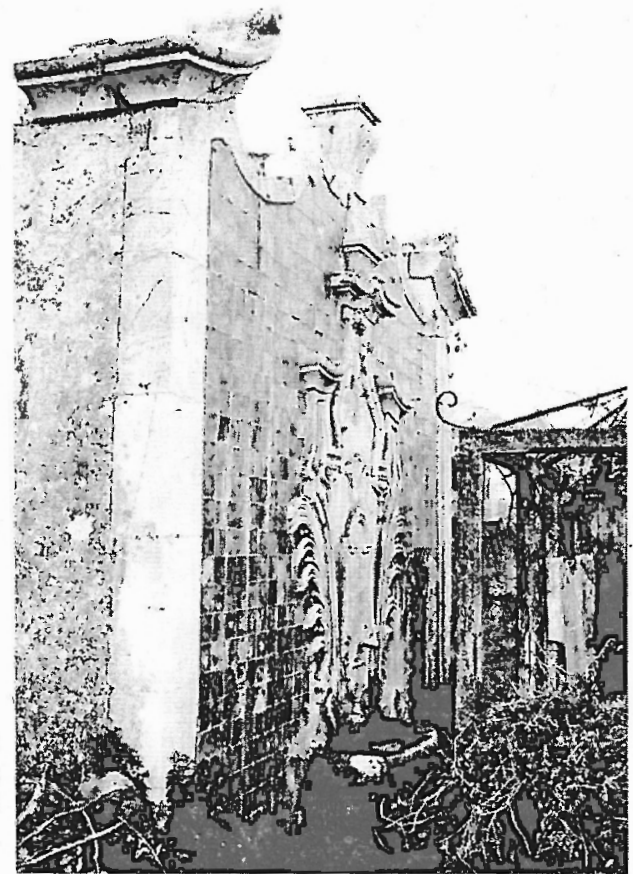

Foto 12 - O Rio Alcoa na "Cerca" junto à antiga Olaria, com a ponte e o açude cistercienses (P.TAVARES, 2000)

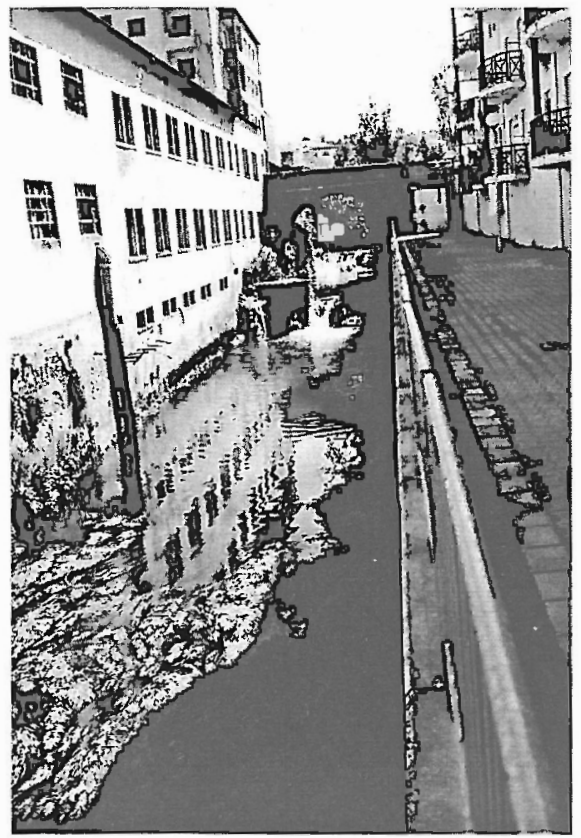




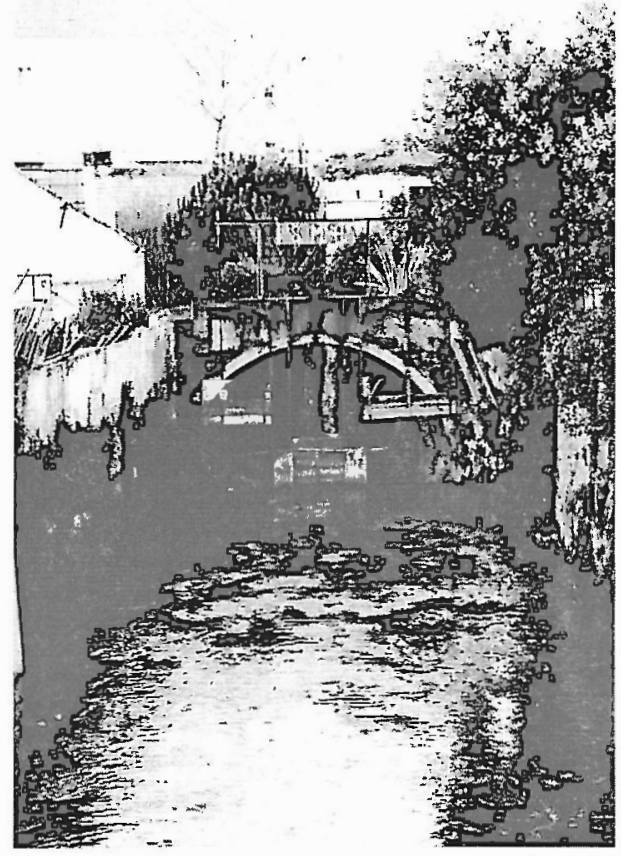

Foto 13 - Ponte da "Alimentícia" no

Rio Alcoa, com engenho para alimentação hidráulica da Central Eléctrica, outra "jóia dormente" da Arqueologia Industrial pós-cisterciense (P.TAVARES, 2000).

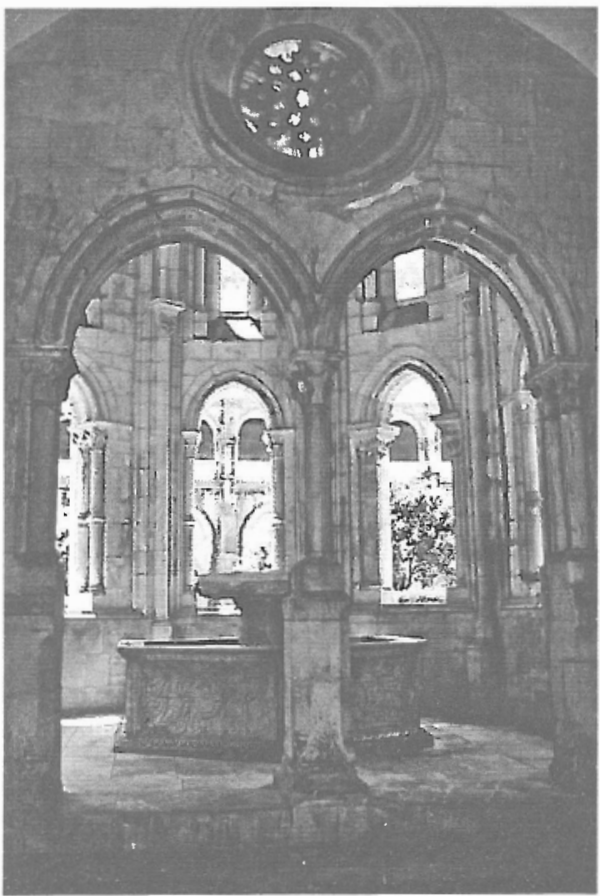

Foto 15 - Edícula do Lavabo no Claustro do Silêncio, frente à porta do Refeitorio (P.TAVARES, 1999).

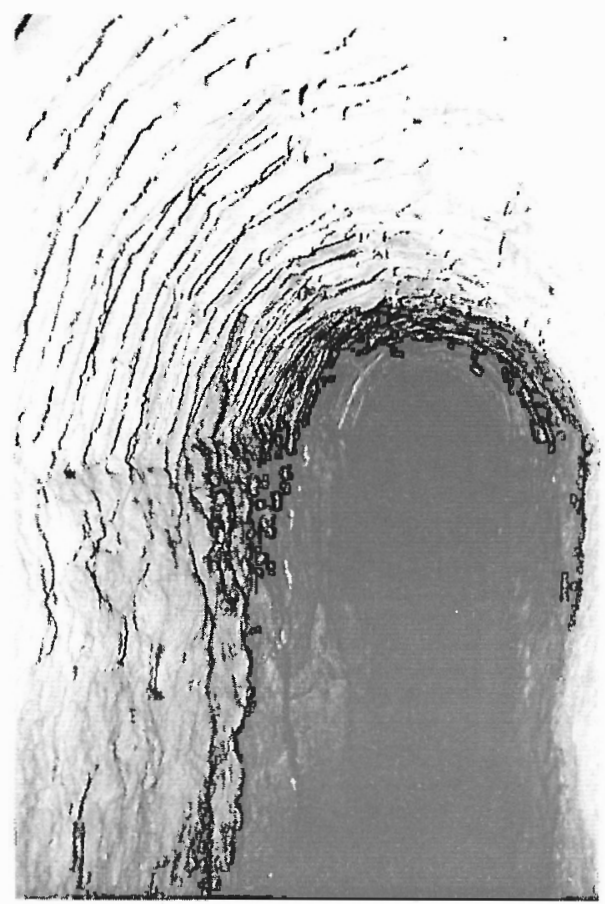

Foto 14 - Galeria para a Conduta de Água Potável na "Cerca", na aproximação ao Mosteiro

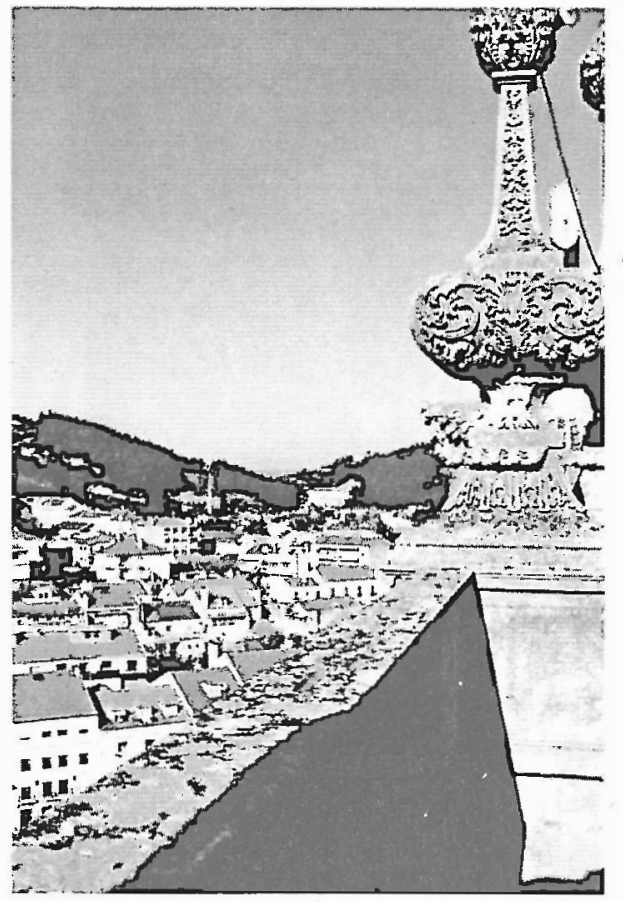

Foto 16 - A "Garganta" da Fervença vista do cimo da Torre Sul do Mosteiro, com o casario de Alcobaça em baixo e os Campos do Valado ao fundo (P.TAVARES, 1999). 
local à água que os levou a desenvolver Sistemas Hidráulicos de protecçãoe de segurança, de utilização industrial e agrícola, de drenagem e saneamento e de lazer e utilização urbana. Em cenário porém de inesperado risco, mas de aliciante desafio. Desafio esse assumido pelos Cistercienses de entãoe assimilado pela Alcobaça nascida à sua sombra, mas progressivamente esquecido pela sucessão das gerações pós-cistercienses.

É interessante referir que foi só no séc. XVIII, que Rousseau e Voltaire romperam radicalmente com o conceito de que a Natureza, emanação divina, era a única responsável por todas as calamidades. Afinal, "o Homem e a Sociedade têm a capacidade de interferir sobre o seu destino".

A Hidráulica Monástica teve uma importância relevante na concepção, implantação, desenvolvimento e exploração da Abadia de Alcobaça, incluindo ConjuntoMonumental Edificadoe "Cerca". O Sistema Hidráulico Cisterciense por um lado, e a matriz abacial por outro, ambos convivendo sobre plataformas aluvio-sedimentares em evolução, formavam um sistema de causa-efeito, condicionando-se reciprocamente na implantação, na concepção e na Arquitectura Abacial.

Embora marcadamente determinantes desses factores, os Rios em Alcobaça sãò eles próprios modificáveis face às necessidades evolutivas ou expansivas da grandeza claustral, num cenário que padece dos efeitos das cheias resultantes da implantação delicada de Alcobaça na sua Planície Aluvionar e do efeito do Clima Mediterrâneo.

Notáveis são também os trabalhos observados de movimentações e depósitos de terras. Constata-se ter havido alteração da topografia e configuração locais, bem como a ocorrência de cheias cominundações de excepção, causando depósitos aluvionares de monta, bem como "assentamentos diferenciais" brutais nos Claustros do Cardeal e da Biblioteca e no Palácio Abacial, com danos apreciáveis, temas estes ainda não devidamente estudados einvestigados em Alcobaça.

Cheias marcantes, houve-as em:

- 1437 (com inundação do Mosteiro) no reinado de D. Duarte,

- 1475, no reinado de D. Afonso V / D. João II, no mesmo ano da oficialização dos Abades Comendatários de nomeação Régia (uma desgraça nunca vem só!),

- 1772, por ironia em dia de S. Martinho a 11 de Novembro, no reinado de D. José,

- 1893, a 8 de Janeiro, já em era pós-cisterciense,

- Testemunhos mais recentes, referem também cheias de monta no início da década de 40 do séc. XX e o novo séc. XXI acaba de nos deixar a marca da temeridade da água, com as impressionantes chuvadas da tarde de 5 de Maio de
2000 (tendo a água, em ambas as situações, alcançado a ponte da Fonte Nova, na Bacia do Rio Baça).

É curioso observar que as Linhas Gerais do Sistema Hidráulico Cisterciense da Abadia, desenvolvendose obliquamente em relação ao Conjunto Edificado, condicionaram mais o crescimento urbano de Alcobaça, do que a imposta orientação Nascente-Poente do eixo da naves da Igreja e toda a matriz claustral ortogonalizada que se foi desenvolvendo.

A Alcobaça secular e urbana cresceu à sombra do seu Mosteiro Monumental, localizada como "rolhão" no "gargalo" de saida da Bacia Hidrográfica referida dos Rios Alcoa e Baça, tentando aproveitar as zonas mais planas e de mais fácil edificação, não pertencentes à "Cerca", bem como as zonas imediatamente adjacentes. Não será por acaso que se constata que todas as outras Povoações estão lá bem no alto, nas linhas decumeada e bem longe de quaisquer outras interferências de escoamento hidráulico (Aljubarrota, Benedita, Vimeiro, Cela, Vestiaria, Turquel, Évora de Alcobaça).

\section{Terramotos}

Em Alcobaça, há registo de Terramotos diversos, na crença popular por vezes associados a avisos ou a castigos divinos:

- 11 de Julho 1335, Sábado, no reinado de D. Afonso IV (na crença "associado" ao início da luta entre o Rei e seu Filho, o Infante e futuro Rei D. Pedro),

- 24 de Agosto 1356, dia de S.Bartolomeu e ao pôr do Sol, também no reinado de D. Afonso IV,

- 12 de Março 1528, $5^{\text {a }}$ feira à entrada da missa, no reinado de D. João III,

- 26 de Janeiro 1531, pouco antes do amanhecer, também no reinado de D. João III. Foi neste cataclismo, também bem sentido em Lisboa, que caiu parte do frontespício, incluindo a imagem em pedra de Nossa Senhora que, como Raínha do Céu e da Terra, é a Padroeira de todas as Abadias Cistercienses (Exordio de Cister). A imagem caiu sem qualquer quebra, o que foi considerado milagre, tendo sido colocada em nicho na Ala Sul do Claustro do Silêncio e alvo de outros milagres. Mas foi tal o terror dos monges, que durante quinze dias não ousaram voltar a dormir dentro dos edifícios monacais,

- 1 de Novembro 1755, dia de "Todos os Santos" e à hora da missa, no reinado de D. José, um dos mais bem conhecidos tremores de terra da História Portuguesa, sobretudo devido aos efeitos que teve em Lisboa, capital do Reino.

Até ao séc.XVI, as "calamidades" são inventariadas por Frei Manoel dos Santos, na sua "Descrição do 
Real Mosteiro de Alcobaça", 1716. Esta obra complementa outra do mesmo autor, a "Alcobaça Illustrada ... Prymeira Parte", 1710. Os dados que refere, revelam ciclos da ordem de duzentos anos entre periodos de actividade sísmica. Bernardo VILLA NOVA, na sua "Breve História de Alcobaça" (Reedição c/aditamentos 1995), refere ainda terramotos em 1422, tendo destruido uma Torre do Castelo, em 1563 e em 23 de Abril 1909, tendo aberto fenda na Sala dos Reis.

O Claustro de D.Dinis, iniciado em 1308 sob a mestria de Domingo Domingues, conforme lápide frente à Sala do Capítulo, e com sobreclaustro determinado no seguimento da visitação do Abade de Pietra em 1484, também foi alvo de quedas por terramotos e de reconstruções. A mais famosa adaptação, com o sobreclaustro, teve início no Abaciato de D.Jorge de Melo (1505/1519), em estilo Manuelino e sob a direcção de João de Castilho.

As acções sísmicas traduzem-se em fenómenos oscilatórios/vibratórios, de frequências e amplitudes variadas. A "frequência própria" de uma estrutura, de uma máquina, ou do que for, corresponde à frequência a que essa estrutura ou máquina é mais sensível, podendo a persistência de fenómenos oscilatórios próximos da "frequência própria" levar a estrutura à ruina (por exemplo, os condutores de automóvel podem sentir bem a vibração de toda a viatura em determinadas velocidades; vibração que decresce ao aumentar ou ao diminuir a velocidade; pela mesma razão se calibram os pneus). Conforme o tipo da acção (sismo), bem como o tipo e a "frequência própria" da estrutura atingida, os efeitos podem variar de negligenciáveis mesmo sob forte abalo, a devastadores, mesmo que em menor tremor. De igual modo, sismos há que tendem a danificar mais as estruturas em altura e outros que atingem mais as estruturas em desenvolvimento horizontal.

Adiante será feita observação genérica relativa à diferenciação dos efeitos dos sismos e das inundações no Mosteiro de Alcobaça.

\section{Incêndios}

É natural que tenham tido lugar diversos incêndios, como era habitual, dada a natureza e condições das construções e do modo de vida. Citam-se três, em épocas distintas:

1 - na "Câmara do Dom Abade", tão intrigantemente localizada "entre as duas torres", mas dificilmente imaginada (Saul A. GOMES, 1998):

... "Estão documentadas as obras de vulto que o abade D. Estêvão de Aguiar executou na sua câmara residencial entre 1438 e 1439. Situada entre "as torres" do Mosteiro - dado documental que poderá ser esclarecedor para a reconstituição da fisionomia arquitectónica do Mosteiro naquele tempo -, os aposentos abaciais tinham câmara e capela privativa. Deveria tratar-se de uma câmara residencial construida sobretudo à base de madeira, material mais efémero e contrastante com a estrutura e os materiais arquitectónicos básicos do edifício, definidos nos princípios regulamentadores das construções cistercienses. Compreende-se, assim sendo, que fosse uma estrutura arquitectónica propícia a incêndios, como parece ter sucedido, se bem interpretamos a referência datada de Junho de 1438 às "cousas do dom abbade [...] que arderam na casa"..."

2 - incêndio de 1525, na Capela mor do Mosteiro, que originou um inquérito exaustivo, com o mérito de ter legado uma interessante descrição da comunidade monástica de então,

3 - os incêndios perpetrados em 1811 pelas tropas do Conde d'Eirlon, por altura da retirada da Terceira Invasão Francesa (Massena), queimando partes no Claustro do Rachadouro (Natividade, M.V.. no Centenário do seu Nascimento, 1960). Também violaram, com quebra e profanação, os túmulos de D. Pedro e de D. Inês de Castro.

O incêndio do belo Coro Manuelino em madeira de bordo, com 156 cadeiras, todas trabalhadas e singulares, com figuras em meio relevo e estatura natural, queima essa geralmente atribuida ao mesmo vandalismo das tropas em retirada, crê o autor tratarse antes de um acto de pura gestão militar, embora de flagrante lesa-património. Face à determinação do comando britânico (Sir Arthur Wellesley, já Duque de Wellington) na retirada do Buçaco para as "Linhas de Torres Vedras", em não deixar nada às tropas inimigas (comida, lenha, armas ou ferramentas) naquele Outono fatídico de 1810 , a utilização da madeira do Coro terá sido o recurso das tropas invasoras para encontrar o combustível para queima de que careciam. Caso o Coro Manuelino tivesse sido incêndiado "in loco', a "carga térmica" seria de tal ordem que teria causado bem mais elevados prejuizos: pedras e cantarias partidas, eventual colapso de algumas estruturas, naves, transeptos, deambulatório e capelas completamente cobertos de negro do fumo, destruição do orgão localizado imediatamente por cima do coro, grandes danos causados no altar barroco e dotado de profusa estatuária barrista monumental (ambos, orgão e altar, foram apeados na década de trinta passada, pelos Monumentos Nacionais, na fase de re-integração do Mosteiro).

Quanto à fama do incêndio da Câmara Municipal na Vila, com todo o seu Arquivo, bem como da célebre Fábrica de Lençaria, também cai em cima das Tropas Napoleónicas, embora a última é bem mais provável ser assacada à oportunidade criada às Tropas Britânicas no citado recuo para as Linhas de 


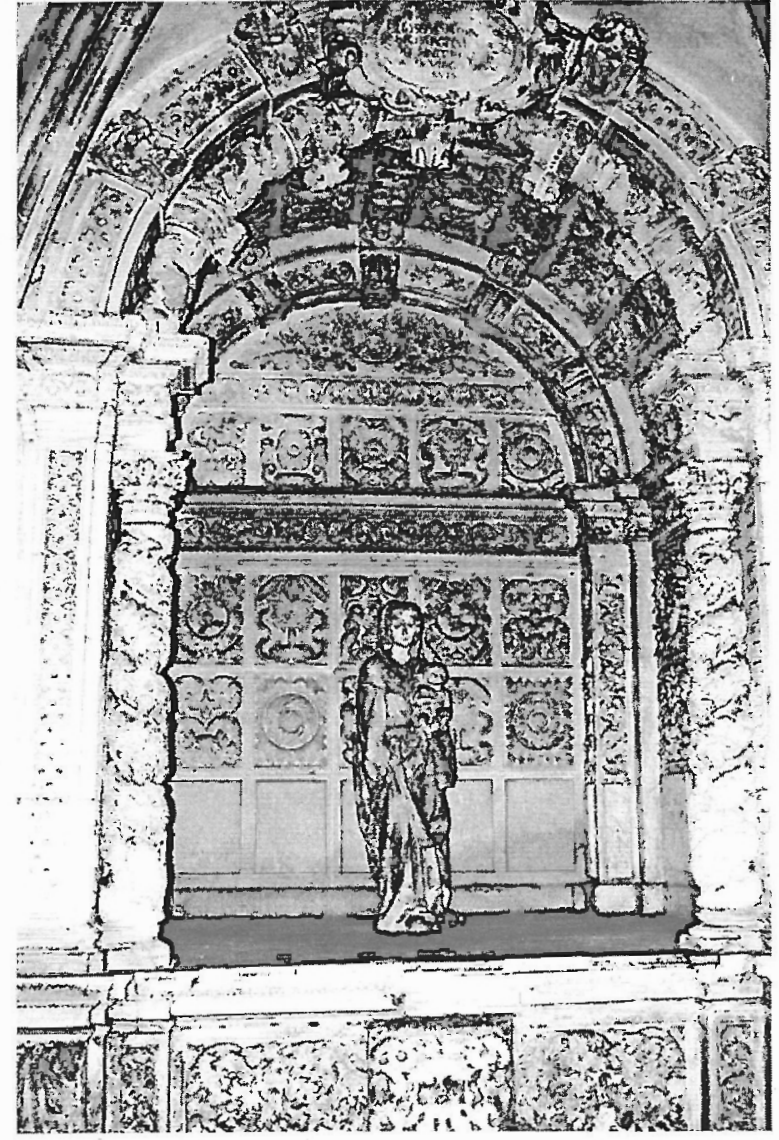

Foto 18 - Dez séculos de Mosteiro de Alcobaça,

vistos da Janela da Edícula do Lavabo:

- sécs. XII+XIII: As paredes laterais ameadas da Nave Colateral Norte;

- séc. XIV: O Claustro do Silêncio ou de D.Dinis (Piso térreo);

- séc. XV: Primeiras construções do sobreclaustro;

- séc. XVI: $\quad$ Sobreclaustro Manuelino; Janela da Edícula do Lavabo;

- séc. XVII; Descansonesta "janela", devido ehiperactividades noutros locais!

- séc. XVIII: As Torres da Fachada Barroca:

- séc. XIX: (início séc. XX) Colunelos e parapeitos do sobreclaustro (A. Fuschini):

- séc. XX: $\quad$ Arranjo das janelas da Nave e dos colunelos do sobreclaustro; Coberturas novas; Laranjeiras e buxo:

- séc. XXI: A objectiva da máquina e o olho do observador (P.TAVARES, 1999).
Foto 17 - Nicho de $N^{a}$ Senhora do Claustro, na Ala Sul do Claustro do Silêncio, edificado no acidente proporcionado pela passagem das condutas de Agua Potável. Em baixo nota-se uma carranca, cuja boquinha aberta é um "trop plein" ou tubo avisador de entupimento naquele sistema hidráulico sensível (P.TAVARES, 1999).

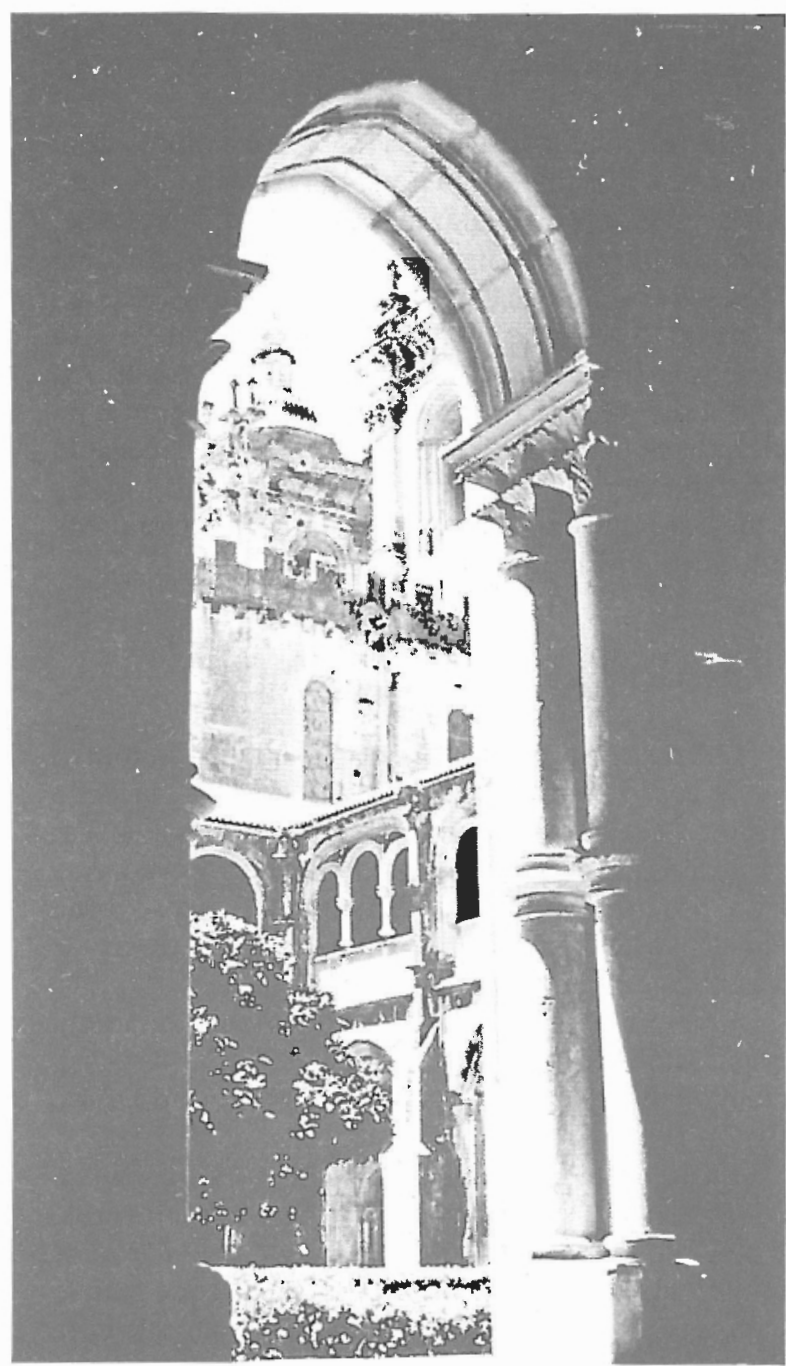


Torres Vedras, de liquidarem uma incómoda concorrência à indústria inglesa (como os Drs. Bernardo Vila Nova e Luis Rosa já chamaram a atenção em épocas distintas e ampla literatura nacional dos sécs. XIX e XX refere, por exemplo C., F.A. de S., 1840).

Manoel dos SANTOS, na sua citada obra "Descrição do Real Mosteiro de Alcobaça" (1716), dá-nos duas "advertências", relativas ao "Lageado"e à "Machina", no sentido de realçar a boa construção em relação à resistência aos incêndios e, eventualmente, em relação às acções sísmicas: uma refere-se ao lageado de pedra branca "... sem que se veja em tam grande edificio huma taboa, salvo nas portas e no interior das cellas dos monges". A outra refere-se ao Sistema Estrutural, a "machina", onde "tam grande mosteiro se firma sobre arcos no alto e no baixo; os que estam descubertos são todos de pedra marmore e pelo interior das paredes vam também arcos parte de pedra e outros de tijolo".

\section{Raios e Faíscas}

Há referências diversas a Raios e Faíscas com danos nos Edifícios Abaciais, que se omitem aqui, por de menor relevância. Já na era pós-cisterciense, houve estragos na Torre esquerda do Mosteiro em 1881 e na Estátua de D. Afonso Henriques e Fachada Norte do Dormitório em 1952 (cuja reparação, levada a cabo pelo Pai do Escultor José Aurélio, de Alcobaça, veio a revelar existir uma bola em prata, com uma relíquia de lenho dentro, na coroa sobre a cabeça do Rei fundador do Reino e do Mosteiro, conforme se pode constatar nos Arquivos da Direcção Geral dos Edifícios e Monumentos Nacionais).

\section{Acção Eólica}

O Vento, Ar em movimento, enquanto ciclónico ou de acção persistente, também pode ser causa de risco e de perda patrimonial e de vida humana. Tal como a Água, o Vento é gerador de energia e, controlado, produz trabalho útil. Tal com a Água se torna num fluxo líquido em movimento, o Ar cria fluxos de massa gasosa de enorme capacidade.

Embora não haja registos de monta de ruina arquitectónica por causas eólicas em Alcobaça, há contudo marcas claras da sua passagem no edificado Cisterciense.

Lá diz o ditado da sabedoria popular: "De Espanha, nem bom vento nem casamento"! Se a primeira pode ter um fundo pragmático, já a segunda só tem o valor histórico do momento, pois não é verdade que grande parte dos casamentos reais portugueses o foram com Princesas das Hespanhas?
É interessante notar a diferenciação que, em determinada altura, se passou a fazer na origem litológica do material de construção abacial e que pode revelar dados preciosos dos níveis de utilização aquando a concepção de determinados espaços. Em Alcobaça, as variações das cotas e dos aterros tem sido de tal ordem (o "sobe-e-desce" de Alcobaça!), que a observação das pedras utilizadas dá, por vezes, indicadores relevantes para níveis anteriores, posteriormente alterados.

As Rochas utilizadas na construção abacial são essencialmente de dois tipos, calcárias e grés (arenitos). Ambas em abundância local, ambas de origem sedimentar, ambas do Jurássico e ambas numa panóplia de variação de tipo, compactação e dureza.

Constata-se assim que as rochas de arenito do tipo grés (vulgo "piçarra", constituidas por grãos de quartzo e algum feldspato, aglutinados por um cimento) se comportam bem em material de fundação e enterradas. Sendo porosas, são absorventes da água, que podem manter em largos volumes (no que constituem um dos vulgarizados sistemas de captação de água na região, através da abertura de túneis, denominados "minas"). Húmidas, enterradas e contidas mantêm-se quase que indefenidamente. Porém, se expostas no exterior, a alternância seco-húmido em continuidade e a exposição à acção do vento, desgastaas sobremaneira. Quanto ao calcário, mesmo duro e compacto, é sensível à humidade persistente, comportando-se melhor no exterior do que enterrado. A água da chuva é ligeiramente acidulada e o seu ph $<7$ leva-a a reagir lentamente com o Cabornato de Cálcio, criando sais solúveis que vão formando pequenos alvéolos nas faces das pedras. Alvéolos que se vão juntando em cavidades de maior dimensão e, se na Natureza criam rendilhados, formas e cavernas de rara beleza, no edificado concorrem para a sua destruição.

Deste modo e em determinadas épocas, nos mesmos elementos verticais, encontra-se a utilização das rochas de arenito (grés) para material de fundação e do calcário para as superestruturas. O plano de fronteira (linha nos alçados) revela a separação entre o "quase que permanentemente húmido" e o "quase que permanentemente seco", mostrando curiosos dados de niveis idos e de utilizações modificadas.

\section{Pestes e epidemias, secas e fomes}

Houve um pouco destas calamidades por todo o lado ao longo da História contemporânea dos Cistercienses. As fomes que assolaram a Europa Medieval no seguimento das chuvadas anormais e persistentes de 1314/15, estragando todas as culturas, deixaram um rasto de morte e de destruição. 
Foto 19 - O Orgão e o Altar com três níveis de estatuária barrista monumental, tendo ambos sido apeados na década de trinta passada pelos Monumentos Nacionais, na fase de re-integração do Mosteiro. Postal do $1^{\circ}$ quartel do séc. XX.
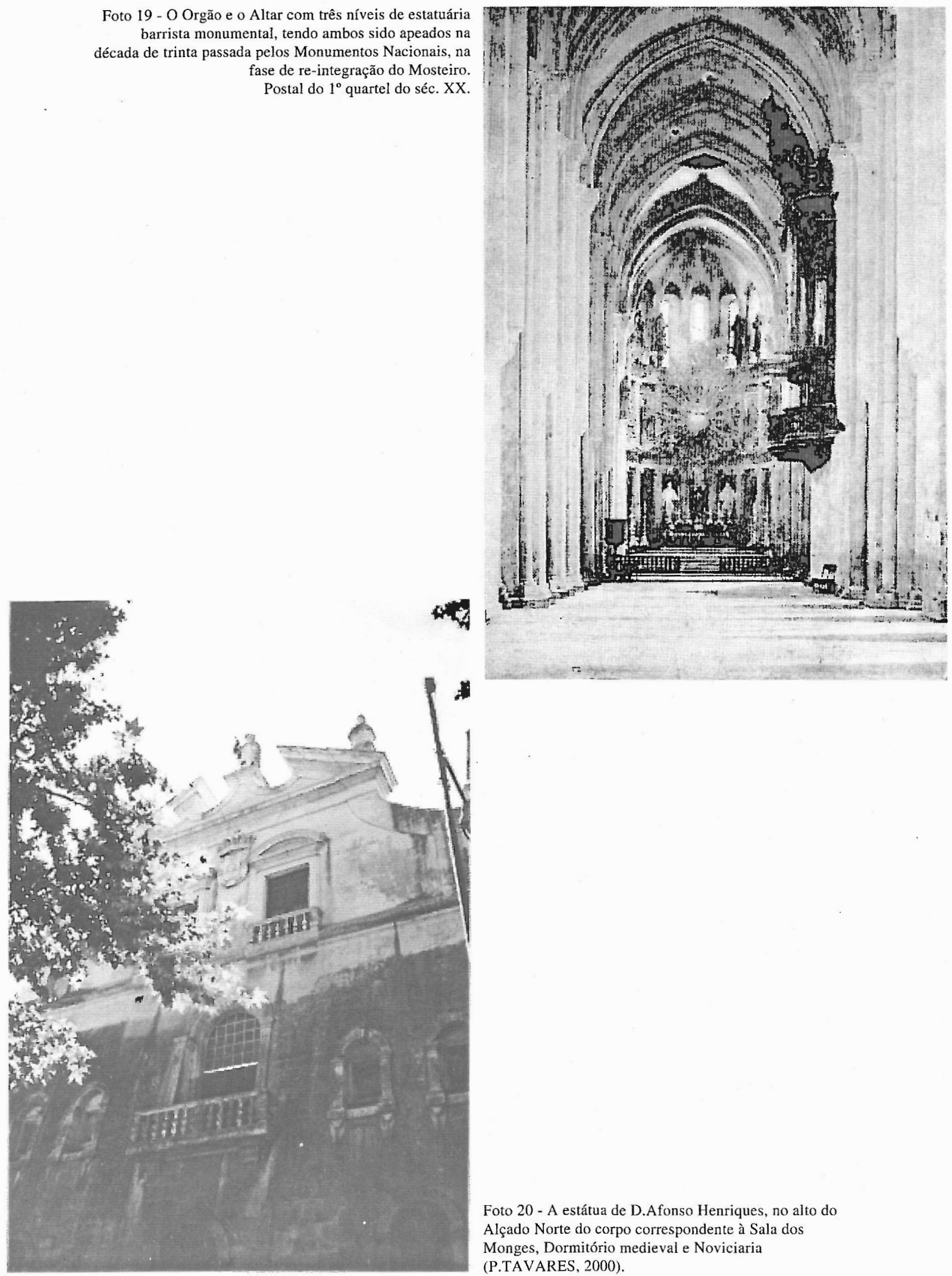

Foto 20 - A estátua de D.Afonso Henriques, no alto do Alçado Norte do corpo correspondente à Sala dos Monges, Dormitório medieval e Noviciaria (P.TAVARES, 2000). 


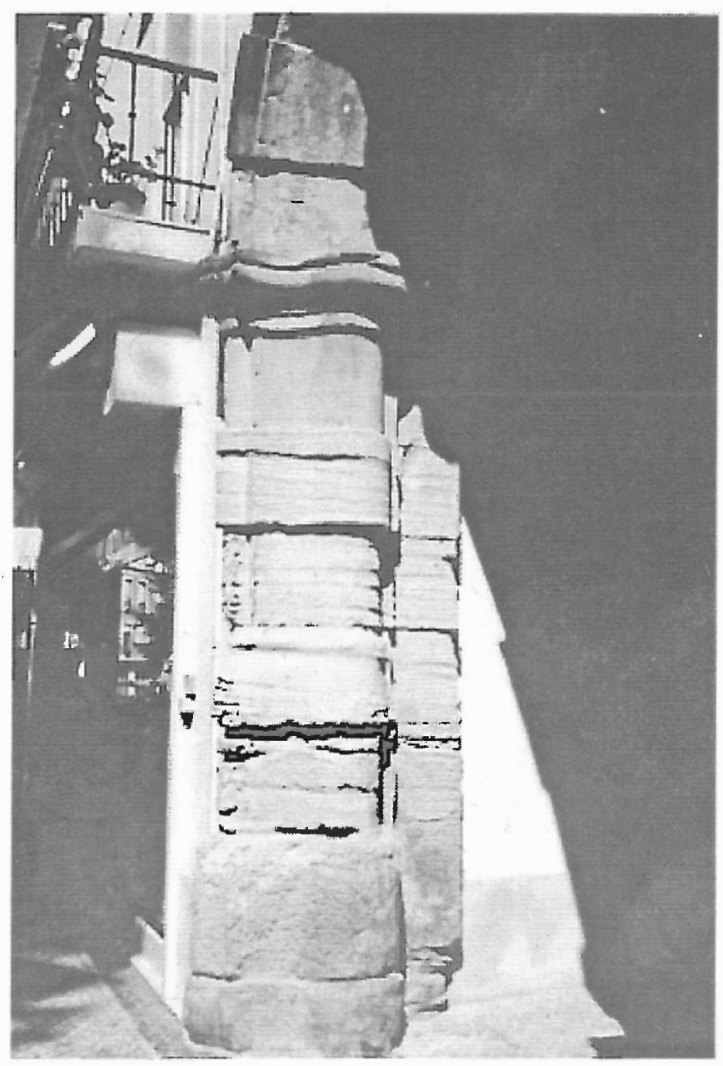

Foto 21 - A acção do vento nas pedras do Arco de Claraval-1 (P.TAVARES, 2000).
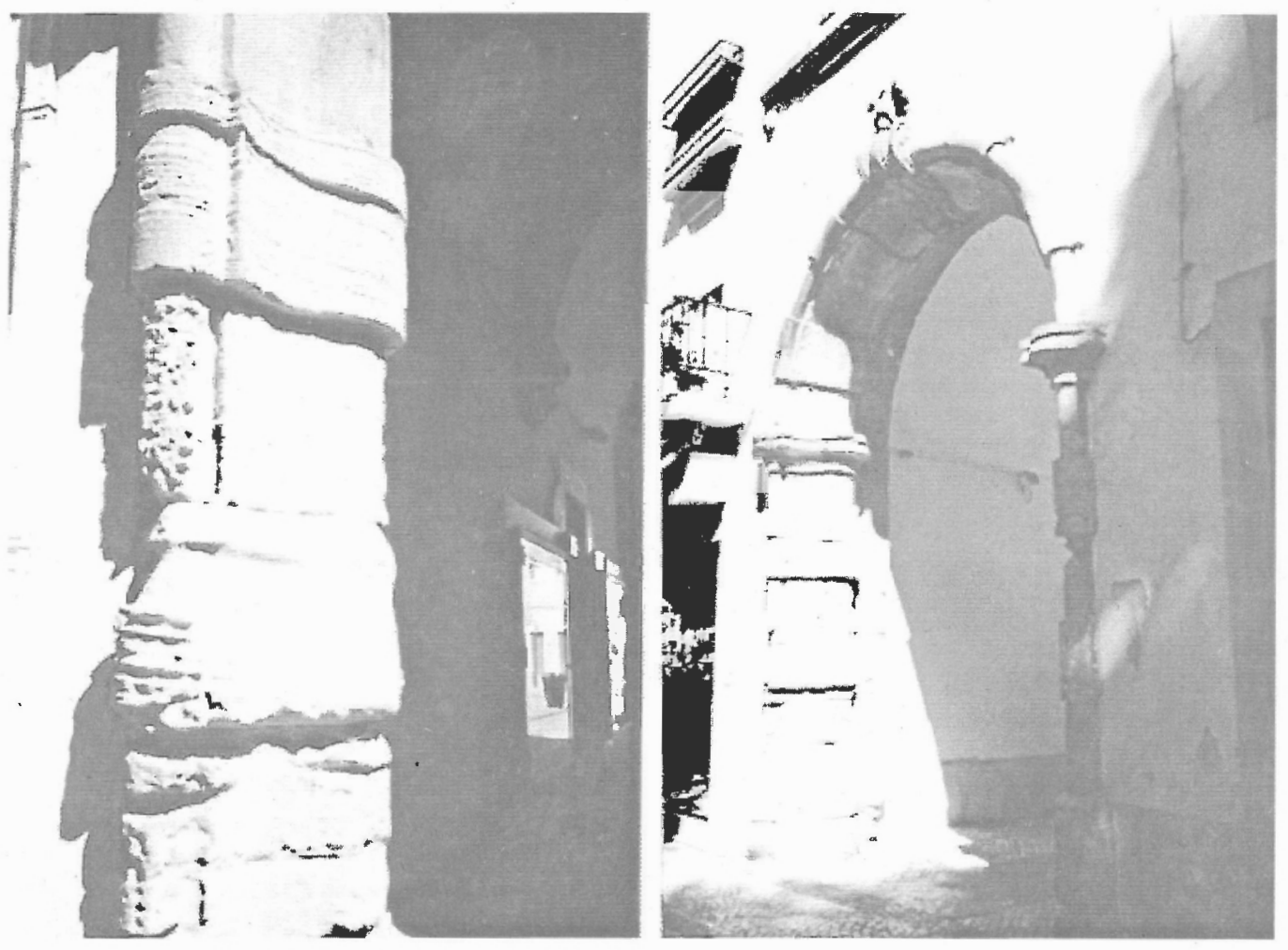

Foto 22 - A acção do vento nas pedras do Arco de Claraval-2 (P.TAVARES, 2000). 


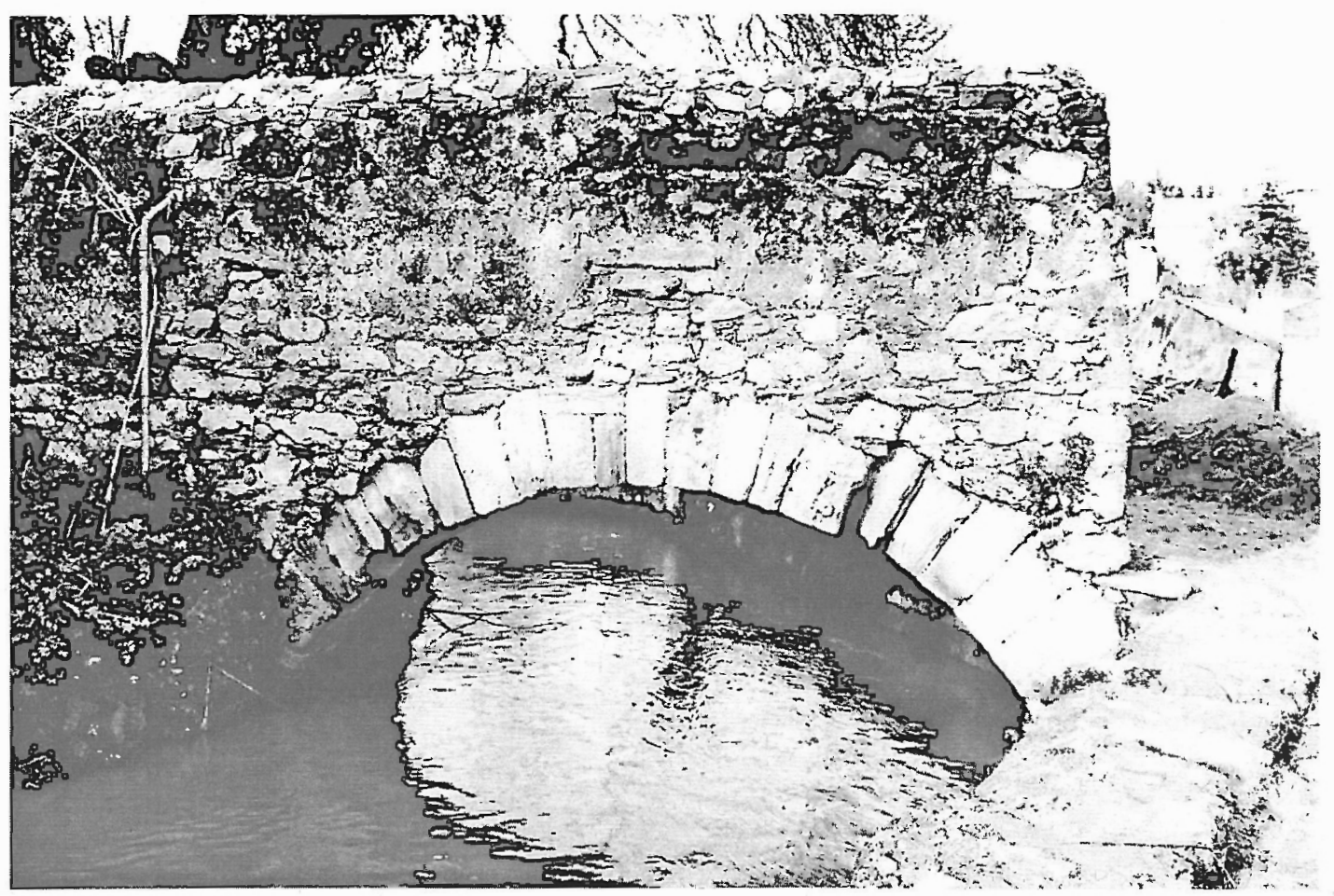

Foto 23 - A acção do vento e da água nas pedras de um arco de muro de sub-cerca, ao cruzar a Levada no Lameirão (P.TAVARES, 1999).

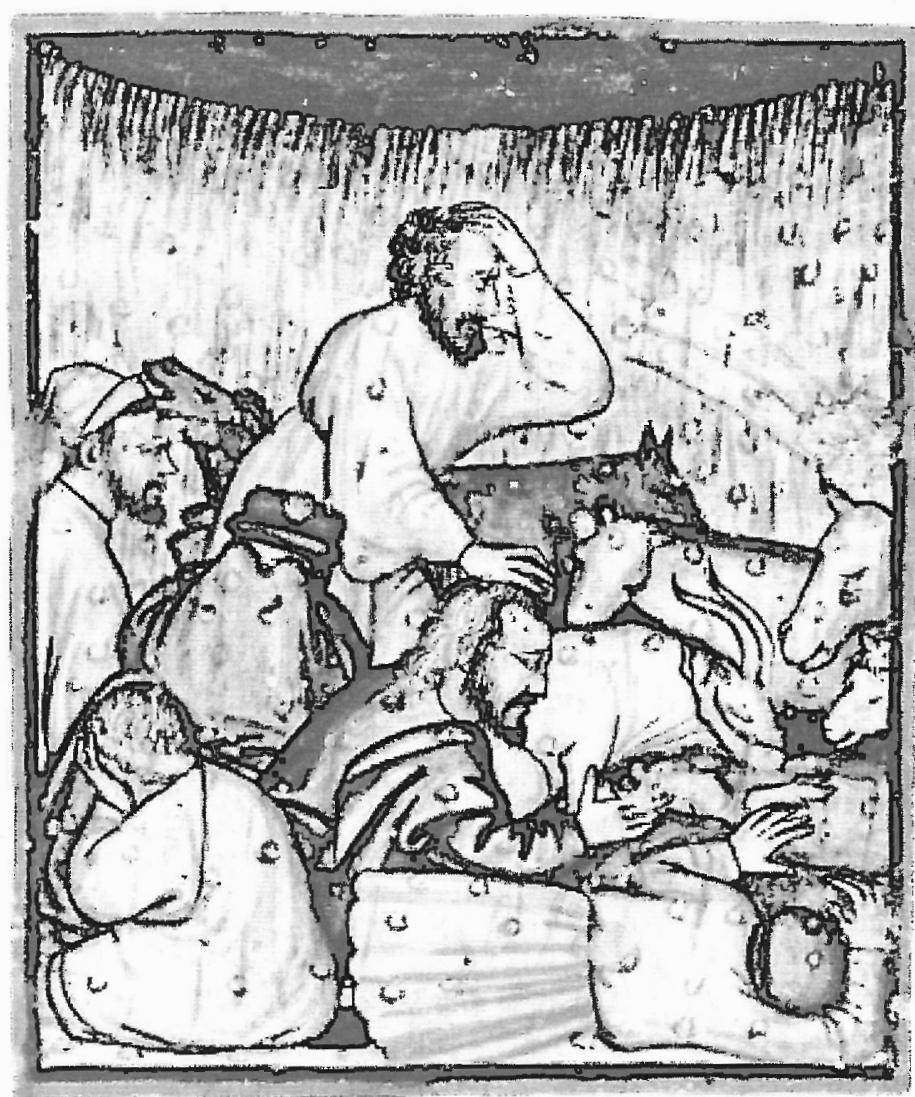

Foto 24 - A Peste sob a forma de uma tempestade de granizo assassino, 'The Bible History of the Jews'. Desenho Italiano, c. 1400

(The British Library) (P. ZIEGLER, 1997). 
A boa administração das comunidades Cistercienses, por um lado, e as condições sanitárias impares (no que o sistema hidráulico desempenhava um papel importante), por outro lado, além do isolamento que buscavam, poderão ter contribuido para minorar alguns dos efeitos nefastos e frequentes destes males.

Mas a Peste Negra (Peste Bubónica, originada na China e trazida para os portos de Itália por mercadores genoveses regressados da Crimeia, onde contraíram a terrível doença no cerco da Tana, sitiada pelos Tártaros) que assolou a Europa Medieval, cobrindoa quase que totalmente em cerca de dois anos, dizimou mais de um terço de toda a População Cisterciense.

Em Alcobaça, só em 1348, em cerca de 3 meses, faleceram 150 Religiosos.

\section{Poluição:}

A problemática acerca da Poluição já vem de longe. Londres foi a primeira cidade a queixar-se da poluição atmosférica, em finais do séc.XIII, devido aos fornos de cal e às quantidades astronómicas de combustível que consumiam. A primeira legislação anti-poluição também vem do Reino Unido, tendo o Parlamento, nessa época sediado em Cambridge, dedicado preocupação ao estado do ar e da água. Seguem-se diversas outras medidas, como por exemplo, as leis em Paris que só permitiam o abate de gado para consumo no Sena a juzante da cidade (J. GIMPEL, 1975).

O termo Poluição não tinha ainda definição na Idade Média, descrevendo-se mais como "corrupção do ar ou da água". No entanto, as fracas condiçôes sanitárias da época, a falta de saneamento (excepto em alguns Mosteiros, em particular nos Cistercienses), a falta de recolha habitual de lixos, conjugados com as fomes, as pestes e o desconhecimento, hão-de ter criado problemas de poluição de elevados contornos. Altas concentrações populacionais nas cidades já eram notórias na Idade Média, acarretando os problemas inerentes. Há registo da lenta subida dos níveis do soio em grandes cidades, motivados pela falta de recolha do lixo e de saneamento.

Quanto a Alcobaça, teve e tem os seus problemas específicos. Os Cistercienses, através da situação hidráulica de excepção que criaram, resolveram os problemas de abastecimento de água, de saneamento e até de evacuação dos lixos orgânicos que produziam. Os meios mais poluentes a nível atmosférico eram prudentemente afastados, dentro do seu vasto Couto. As condições sanitárias eram francamente melhores do que em qualquer outro lugar, mercê da rígida disciplina dos espaços, das gentes e dos costumes.

Mas a Alcobaça secular não tinha os meios, os recursos e a organização para acompanhar essa "pedalada". Ido o conhecimento monástico e crescendo a populaçãoe a sua concentração, enquanto a tecnologia associada à rega e à energia hidráulica se recolocava e continuava a desenvolver, o esgoto-cloaca associado aos rios aumentava desproporcionadamente em relação aos caudais de estiagem do Alcoa e, sobretudo, do Baça. Numa acção de monta e de visão para a filosofia da época, em que "o que não convem se esconde", o prestigiado Ministro das Obras Públicas Eng $^{\circ}$ Duarte Pacheco autoriza a cobertura em tunel do troço urbano do Rio Baça. Resolver-se-ia assim, de uma assentada, o problema da poluição sentida naquela linha de água e criava-se uma nova e central artéria urbana, que iria proporcionar novas frentes de construção. Rua que, Alcobaça agradecida, denominou segundo o seu promotor.

O túnel do Rio Baça, terminado em 1938, tem perto de 700 metros de desenvolvimento, embora a parte terminal já existisse à altura e seja de época anterior, inclusivamente com prédios construidos por cima e com descargas directas na vertical. Quando o autor, pela primeira vez, se abalançou a descer ao rio e a atravessar o túnel, ia à espera de encontrar uma estrutura, grandiosa sim, mas executada em betão armado dos primórdios e portanto já muito degradada. Justificavam esta suposição a data em que a obra se desenrolou e o dinamismo do Ministro e também Técnico, com o desejo de inovar buscando um material e uma tecnologia que começava a ter utilização comum, bem como outra suposição dessa época, errada também, de que "o betão era eterno".

No entanto, o autor confessa a sua surpresa total. O túnel que encontrou é digno da melhor técnica construtiva cisterciense. As longas abóbadas de berço, correspondentes aos vários troços de que se compõe, foram construidas com grandes cilhares de pedra, blocos talhados à perfeição e assentes formando uma estrutura sólida, segundo a filosofia cisterciense: "construir não para os séculos, mas para os milénios"!

O túnel é impressionante e merece a pena ser visitado. Obviamente que não resolveu os problemas de base, o da poluição e o da sobre-construção.

Mas esses, ainda hoje estão por resolver.

Poderia aqui ter lugar um outro capítulo, o da Poluição Urbanística, com referência à ocupação indevida construtiva do solo. Indevida não num sentido legalista, mas num sentido mais humanizado. Trata-se de uma "Poluição do espaço" ou, na terminologia da Idade Média, da "corrupção doespaço" que, por tender a perdurar no tempo, a torna grave e de efeitos onerosos. Aparece muitas vezes "legitimada" pelo Plano, pela Licença, pelo uso. É das mais difíceis de explicar e de demonstrar.

Alcobaça também dela padece. Já vem da História, ou não foi desde o seu nascimento fruto de uma relação de "amor-e-ódio" entre a urbe secular e o seu 


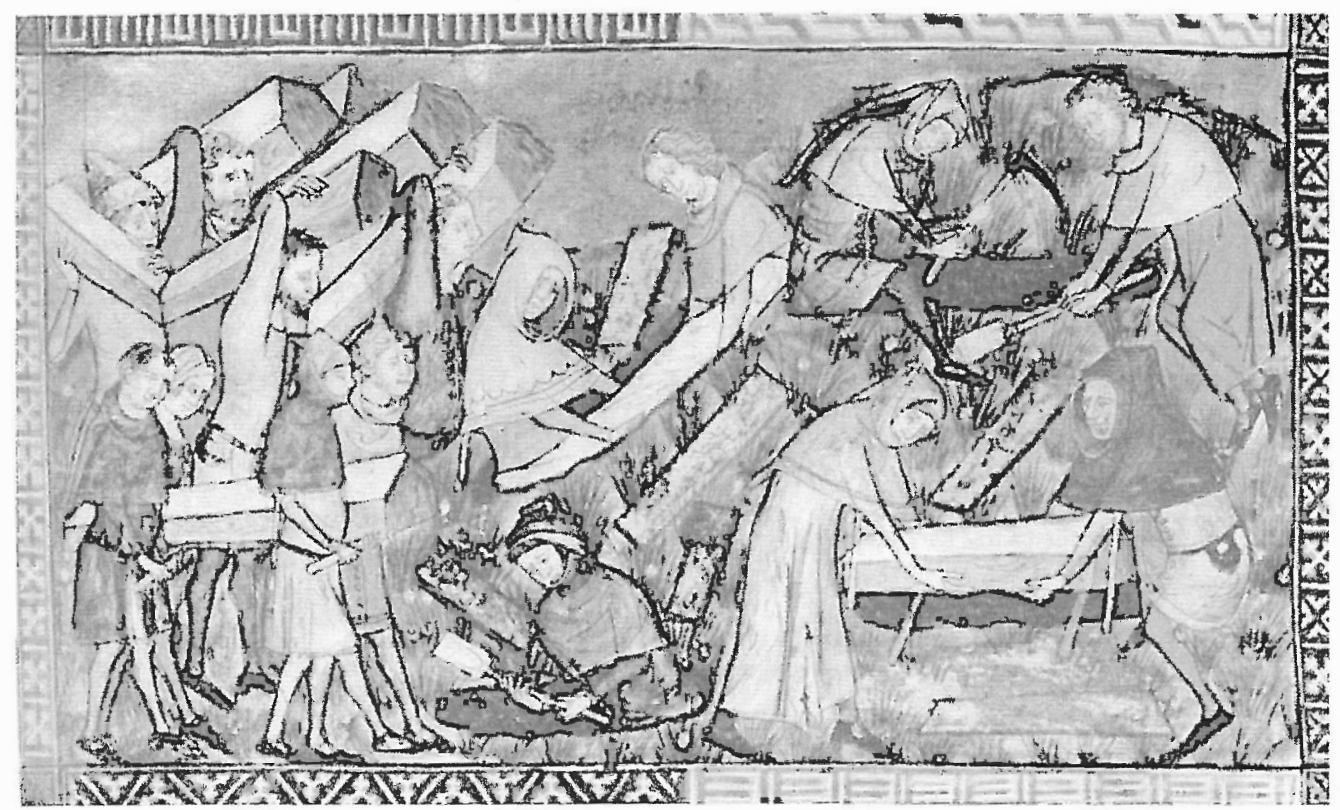

Foto 25 - Enterro de vítimas da peste em Tournai. Desenho Flamengo, 1349-52 (Bibliothéque royale Albert ler, Brussels) (P. ZIEGLER, 1997).

Foto 26 - O Rio Baça pela câmara mágica de Domingos Alvão, mostrando alguma poluição, a Ponte da Travessa da Cadeia e o início da parte mais antiga do túnel com edificação superior. Pode-se ainda observar o poste das linhas de telefone na ponte, já bem ocupado. (Foto Alvão, Porto, início anos trinta - Arquivo C.M.Alcobaça).

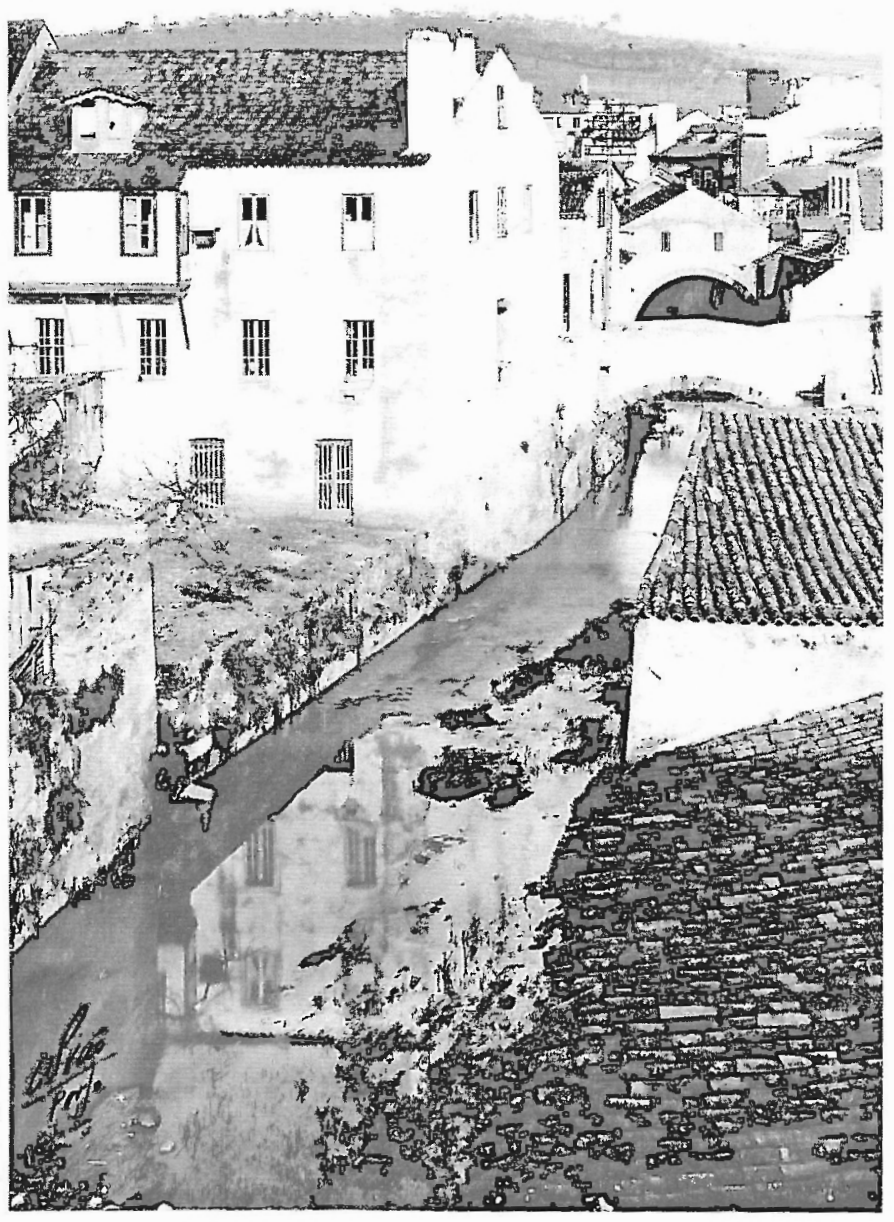




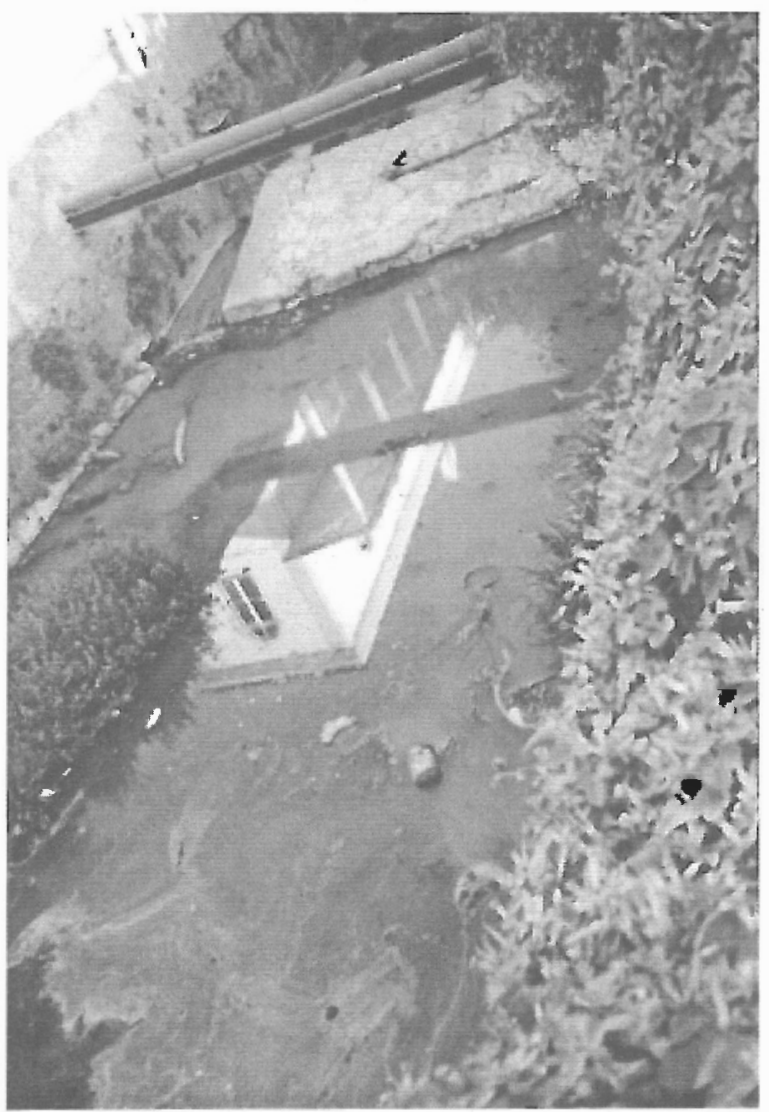

Foto 27 - Poluição no Baça, vendose ainda um pequeno açude para alimentação hidráulica da Central Eléctrica da "Alimentícia", pouco antes da confluência com o Alcoa (P.TAVARES, 2002).
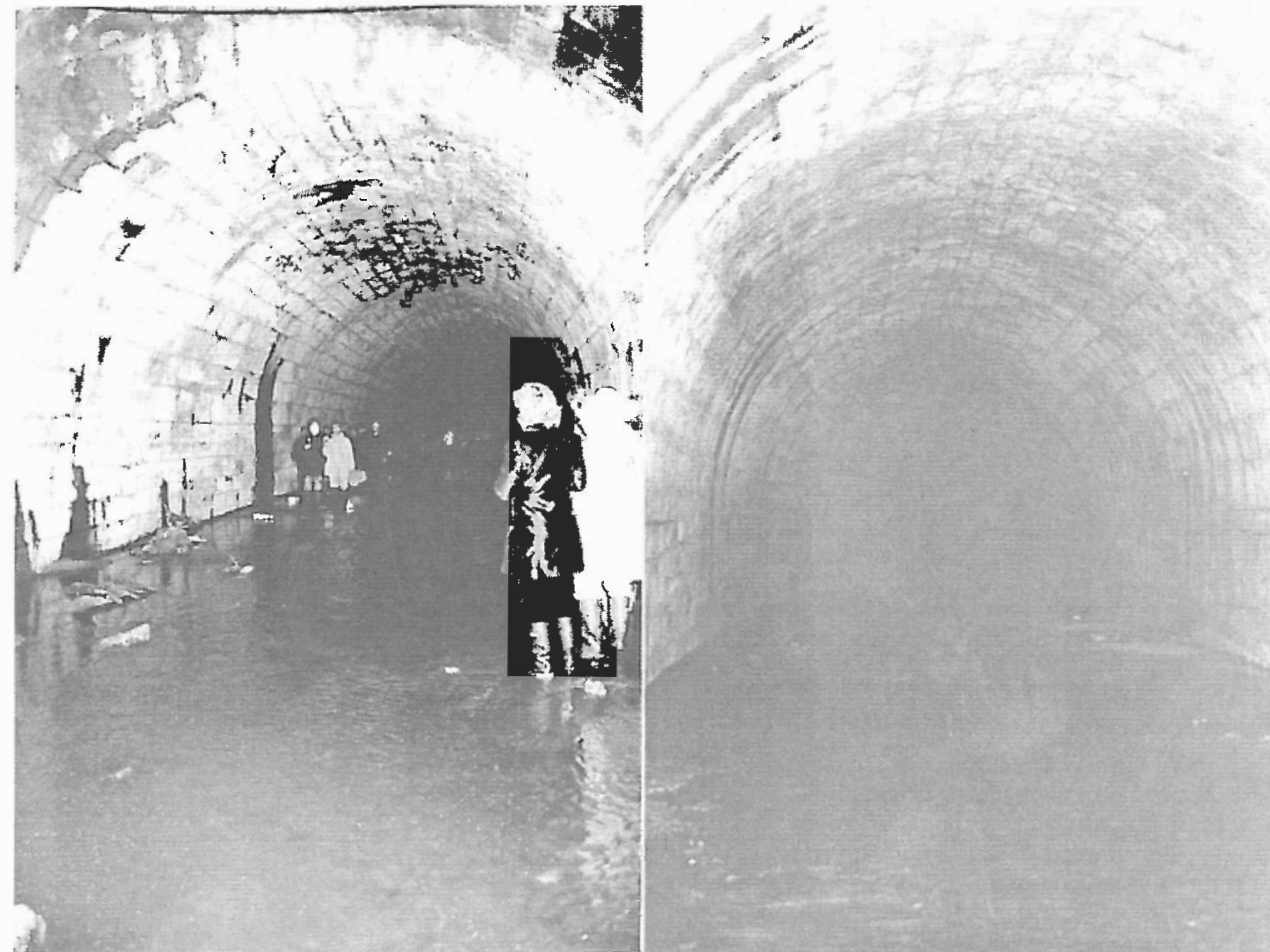

Foto 28 - O Tunel do Rio Baça, obra de Duarte Pacheco de 1938. A melhor obra, mas na filosofia da época, cedo ultrapassada (P.TAVARES, 2001). 


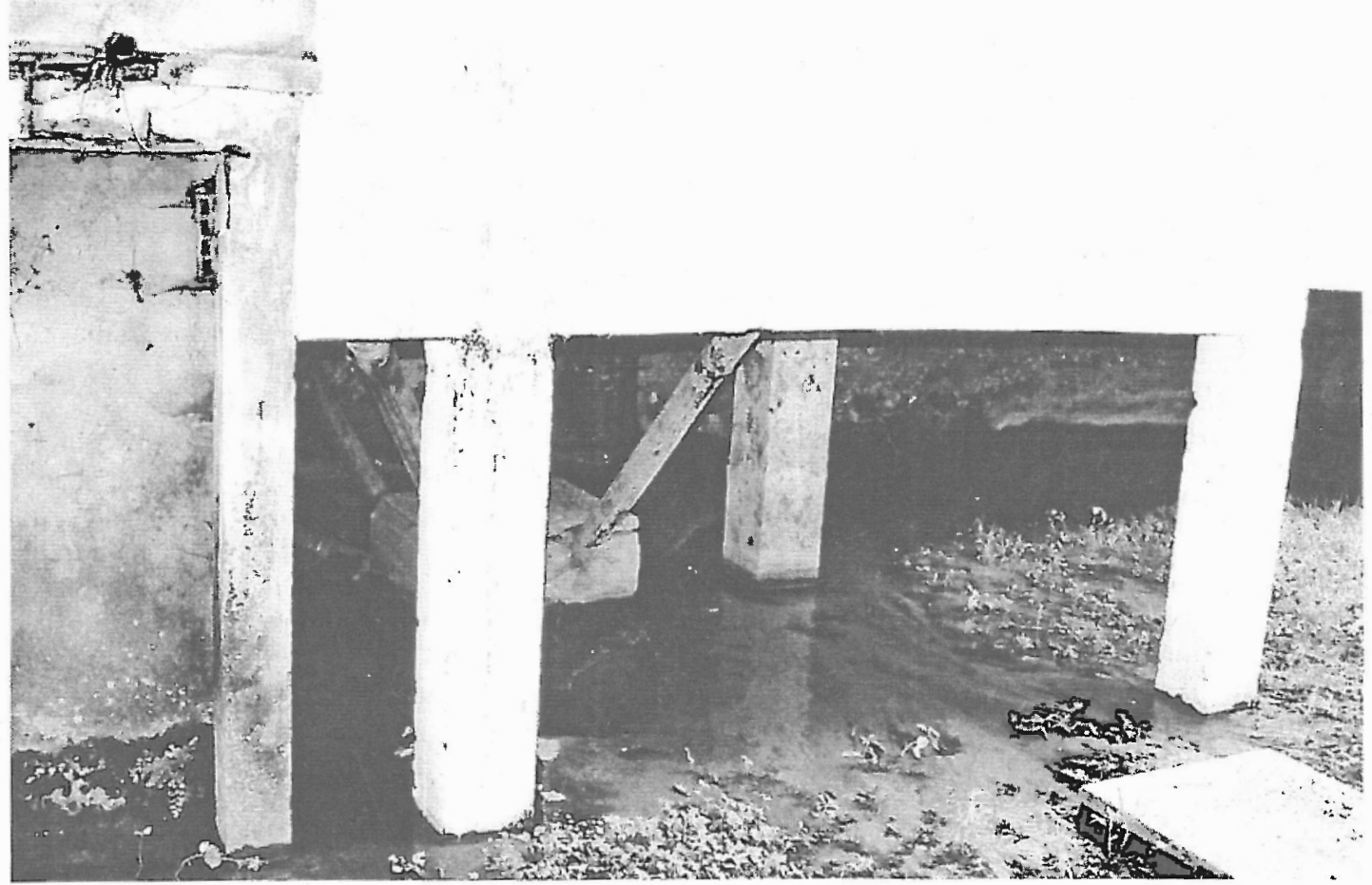

Foto 29 - "Palafitas" sobre a Levada, exemplo da sua ocupação urbana (P.TAVARES, 1999).

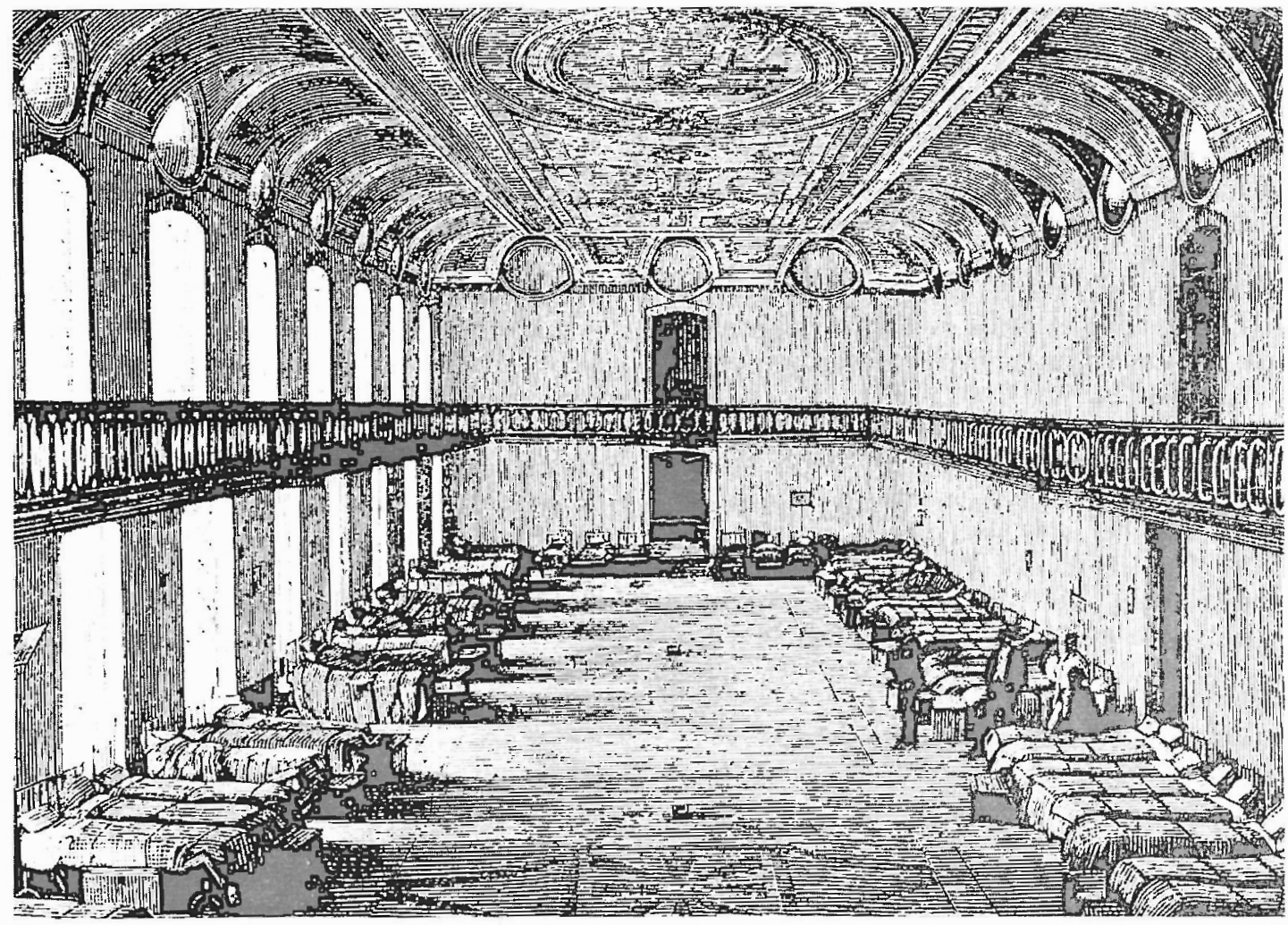

Foto 30 - "Livraria" do Mosteiro de Alcobaça transformada em camarata militar, há cerca de cem anos. Postal c. 1900 (Edição da ADEPA). 
Mosteiro? Relação que assim continua, embora mais distante na convivência e cada vez mais dependente nos "Riscos Naturais".

É um tema sensível, a envolver acesa atenção. Com certa e notória implicação numa avaliação séria e racional dos Riscos Naturais. Mas que, neste escrito, se remete apenas para o seu reconhecimento. Problema que tambémé de segurança patrimonial e de segurança das Populações e que, em Alcobaça, a julgar pela riqueza patrimonial única, pelos factores em análise e pelas consequências sentidas, em muito deveria transcender a elaboração/revisão do PDM-Plano Director Municipal local e se tornar num caso nacional.

\section{Outras Perturbações na vida Monástica}

Como exemplos de Perturbações na vida Monástica de natureza espiritual, doutrinária ou administrativa, já afastados da fronteira dos "Riscos Naturais", mas não menos de um Ambiente hostil, podem-se citar as ideias e reformas protestantes (1517), a introdução da Inquisição em 1536/39 no reinado de D. João III (só abolida em 1821 ao tempo de D. João VI), bem como a nomeação Régia dos Abades Comendatários em 1475 (a Comenda foi abolida por D. João IV em 1642). O sistema de eleições livres dos Abades Cistercienses, base sólida de todo um edifício memorável,játinha sido violentado pelo Papa Gregório XI(1370-78) que, a pretexto do seu papel de "Guardião das Ordens Monásticas", instituiu o seu direito de nomear os Abades, ao que se seguiram as imposições reais do mesmo direito. Tal terá causado, em última análise e na globalidade da Ordem Cisterciense, mais danos morais e materiais que todas as guerras, calamidades e reformas em conjunto.

Quanto a Guerras, Revoluções, desordens ou ocupações, para além das Invasões Francesas, a Guerra Civil culminou, para os Cistercienses em Portugal, com a extinção das Ordens Religiosas pelo Decreto do "Mata-Frades" (Joaquim António de Aguiar) de 30 de Maio de 1834, ainda assinado por D. Pedro IV enquanto Regente do Reino em nome de sua Filha D. Maria II, tendo falecido pouco depois em Queluz, a 24 de Setembro (ainda relativamente novo, apesar de já ter renunciado a duas coroas), qual maldição lançada por S. Bernardo (Fr. Manoel dos SANTOS, na sua "Alcobaça Illustrada" citada, de 1710 , já narrava as "maldições" de S. Bernardo, que caíam em cima de quem se metia com a Ordem Cisterciense, apresentando diversos exemplos).

O que é certo é que os monges Cistercienses, que em todos os casos de guerra ou revolução souberam apoiar e estar do lado ganhador (Fundação da Nacionalidade, Aljubarrota e D. João I, a Restauração e D. João IV, as Invasões Francesas), tinham agora jogado a "cartada errada".
São levados a fugir em 26 de Julho 1833, regressam, voltam a fugir e abandonam definitivamente o Mosteiro em princípios de Outubro de 1833. Com o levantamento liberal de 16 de Outubro desse ano (que deu nome a Rua em Alcobaça), o Mosteiro é ocupado pela População e saqueado! Seguiu-se a tomada de posse pela Coroa, as inventariações e, poucos anos depois o desmembramento de todo este vasto património em Hastas Públicas e vendas de outorga Régia e em cedências de espaços para as mais variadas funções, públicas e privadas.

Depois de quase sete séculos em que os Cistercienses fizeram obra, domaram e adoçaram o território, implantaram a sua estrutura de ocupação física, social e administrativa, revolucionaram a Agricultura através das suas Granja-Modelo, montaram a maior máquina económica de que há memória em Portugal e do seu tempo, revolucionaram a indústria medieval mercê do desenvolvimento da tecnologia hidráulica, edificaram o maior conjunto Monumental Abacial de Portugal (a nave da Igreja é a mais comprida da Península Ibérica), foram senhores de 3 Coutos (Alcobaça, Ota e Beringel, este perto de Beja), 4 Portos de Mar (Paredes, Pederneira, S.Martinho e Alfeizerão), 2 Estaleiros Navais, 37 Celeiros, 42 Adegas, Pizões, Moinhos, Lagares de Azeite, Salinas, Matas, Olarias, Unidades Metalúrgicas, Fornos de Telha, Fornos de Cal, Curtumes e de outras inúmeras propriedades (M.A. MARQUES, 1998), foram mentores da Cultura e da sua difusão, criaram as primeiras Aulas em Portugal e participaram na fundação da Universidade (quantos Monges de Alcobaça foram lentes na Universidade de Coimbra!) e foram ainda elos decisivos no bem estar do Estado e do rumo da História, não só por todos os cargos Reais inerentes, mas fundamentalmente pelo apoio decisivo prestado em momentos-chave (Reconhecimento de Portugal, Aljubarrota, Restauração), depois de tanto tempo a resistir às cheias, aos terramotos, às ruinas consequentes, como se fossem desafios ou penitências enviadas pelo Poder Divino, para melhor moldar e temperar a sua capacidade de resistência, de força de vontade e de aceitação (Justiça, Temperança, Fortaleza e Prudência, são as 'quatro Virtudes' bem presentes na Frontaria do Mosteiro), eis que os Cistercienses em Alcobaça sucumbem finalmente ao ... medo. Medo do Poder ganhador e medo dos Alcobacenses, medo do Povo que eles ajudaram a gerar.

É o que se poderia chamar o Risco Biológico. Não o das situações NBQ (Nucleares, Biológicas e Químicas) do mundo moderno. Porquê então Risco Biológico?

Pela analogia com a relação biológica Mãe-Filho na Natureza. A Mãe, Mosteiro, gere e dá nascença ao Filho, que expele do seu ventre: Recolha dos homoziados que fugiam à justiça Real ao longo do 
séc. XV, sua protecção dentro da "Cerca" (o "ventre" materno) e esmolas da 'micha' e da botica (foi a fase da "gestação"); segue-se o Decreto infrutífero de 1506 de D. Manuel para a Vila de S.Bernardo, para retirar essa concentração populacional da vizinhança do Mosteiro e finalmente o recuo da "Cerca" no séc. XVI, ficando os homiziados de fora e formando o núcleo secular (foi autenticamente o "dar à luz" de Alcobaça); o Filho cresce e aprende à sombra protectora e tutelar maternal; ao atingir o seu grau de maturidade e o desejo de independência, face à rigidez paternal, antagoniza, diverge no idealismo, segue outras bandeiras (foi a fase do crescimento). Na Natureza, muitas vezes a mãe repele o próprio filho, para que ele siga a sua vida e aprenda a ser verdadeiramente independente e autónomo.

Quando finalmente o poder abacial desaparece em 1833, fugido primeiro, despojado depois (fuga dos monges, decreto de extinção), é o Povo de Alcobaça que ocupa o Mosteiro, compra espaços, monta um sem número de actividades, profana, altera, modifica. Goza o Espaço, torna-o útil à sua maneira, desde Teatro a Igreja, de Câmara a Prisão, de Escolas a Bancos, de Correios a Ginásioe Banda, de Repartição Pública a Quartel, de Habitações a Asilo e a Lar. Porém, neste acto secular eblasfemo, salva da destruição o corpo materno. Na maioria dos outros mosteiros, à extinção seguiu-se a demolição, para utilização de materiais de construção, como se de pedreira se tratasse (foi a sorte do Castelo de Alcobaça), ou a ruina, por abandono.

É assim que hoje podemos disfrutar de um raro, belo extenso Conjunto Monumental Abacial Cisterciense. Alcobaça secular, como uma Filha, nasceu do Mosteiro. Mais de três séculos depois, embora em antagonismo com a Abadia materna, quando ela enfraquece e se despoja, é Alcobaça que a ocupa e a salva da morte anunciada.

\section{Novamente a Água, Depósitos Sedimentares e Movimentações de Terras}

Depois da breve listagem havida de eventuais Riscos na Alcobaça Cisterciense (é bem possível que outros houvesse, mostrando-se com um pouco de imaginação ou melhor investigação), merece relevo focar novamente a problemática da Água e do Meio Ambiente e como moldaram e condicionaram a "Aventura Cisterciense". Aventura ou Epopeia esta que se desenrolou em cima de um tabuleiro denominado "Planície Aluvionar".

"Planícies Aluvionares são zonas planas adjacentes aos cursos dos rios e sujeitas a inundação. Constituiem uma das formações mais conspícuas e'espalhadas no globo terrestre. Resultam de processos complexos de erosão e de depósito. Modificam-se ao longo dos tempos e evoluem, não para um qualquer modelo final, mas para a forma que têm no presente ou que tiveram em qualquer momento do passado" (A.G. BROWN, 1997/2000).

Rios e Planícies Aluvionares sempre foram fontes de riqueza para todas as gerações. Com actividades piscícolas e moinhos de água (azenhas) na Idade Média, depois como centros de comércio e também como fontes de energia mecânica para as primeiras indústrias. Tal movimento, à escala Europeia, resultou numa expansão apreciável de aglomerados populacionais nas Planícies Aluvionares, num aumento das pressões para reduzir os inconvenientes das cheias e na mudança de leitos dos rios. A evolução quase imperceptível da utilização de recursos das Planícies Aluvionares, e a gestão e o controlo desses recursos, compõe-se de muitas inovações de origem humana. As Planícies Aluvionares constituiram os meios e os cenários principais para inovação, nomeadamente: irrigação, engenharia fluvial, engenharia de pontes e vias de comunicação, drenagem. Destas, a irrigação é talvez a inovação mais antiga e das mais importantes em termos sócio-económicos e políticos. Na Europa Ocidental/Norte e nas zonas costeiras, a drenagem de águas em excesso foi tentada há mais de 2.000 anos. Modificações palpáveis no cenário da Engenharia de comunicação ocorreram com o apogeu da ocupação Romana (A.G. BROWN, 1997/2000).

A mestria do domínio da Água e da sua utilização útil teve o seu momento de glória na Europa no auge das Instituições Monásticas, onde a sofistificação dos moinhos e engenhos construidos e das levadas concebidas (levadas que chegavam a ter $3 \mathrm{~km}$ de comprimento e se tornavam necessárias para garantir um fluxo de água controlado, orientado e a uma cota que possibilitasse a energia potencial adequada à sua transformação em energia cinética), bem como a diversidade de usos em que eram empenhados, tudo nos deixa um património de surpreendente tecnologia e saber (J.P. TAVARES, 2001).

Artigo recente sobre a Água como Bem Estratégico (J.M.BAPTISTA, 2002) recorda que dos cinco desafios futuros da Água na Europa, dois referem-se ao aumento das cargas poluentes e ao aumento do risco de cheia (através de uma maior frequência e intensidade, devido a desflorestação, compactação dos solos, secagem de zonas húmidas, impermeabilização de zonas urbanas, artificialização dos leitos dos rios e alterações climáticas), tendo-se verificado nos últimos vinte anos, só na Europa, cerca de um milhar de mortos e um milhão de desalojados devido a cheias.

O mesmo Artigo menciona também o impacto (ainda incerto na UE) das Alterações Climáticas, traduzindo-se provavelmente na alteração do Ciclo Hidrológico (ex. na precipitação e no escoamento), 


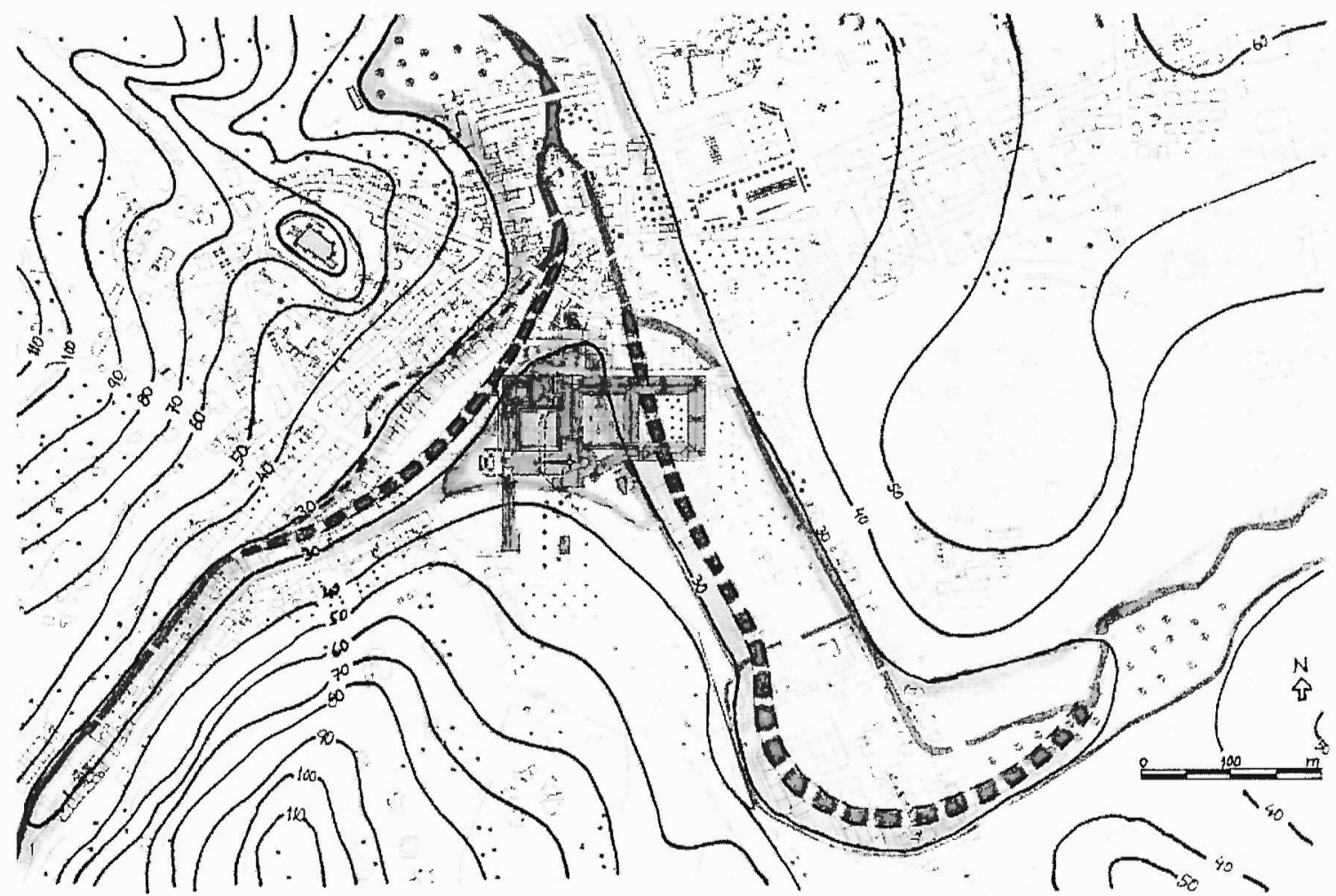

Foto 31 - Planta digitalizada de Alcobaça (C.M.A.) com a demarcação esquemática de áreas de cobertura aluvionar provável à chegada dos Cistercienses, os traçados dos Rios Alcoa e Baça na actualidade e possíveis na Idade Média (a tracejado) e a implantação do "triângulo bom cisterciense", correspondendo cumulativamente a zona (i) quase plana, (ii) com fundação rochosa estável e (iii) bem servida por potenciais fluxos hidráulicos em cotas favoráveis correndo do Alcoa para o Baça (levadas) (P.TAVARES, 2002).
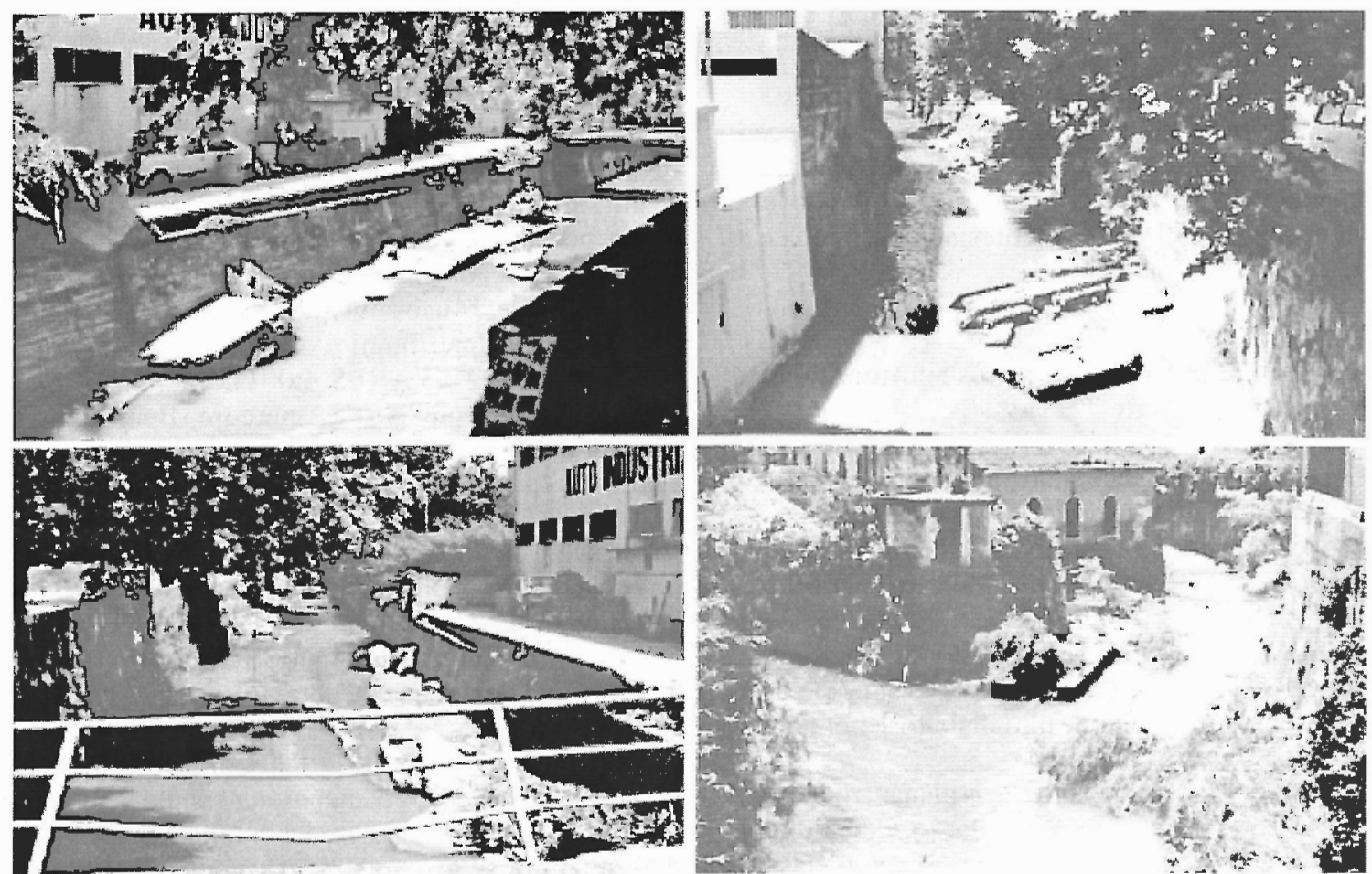

Foto 32 - Efeito das Cheias de 5 de Maio de 2000. Lá que há avisos, há! (P.TAVARES, 2000). 

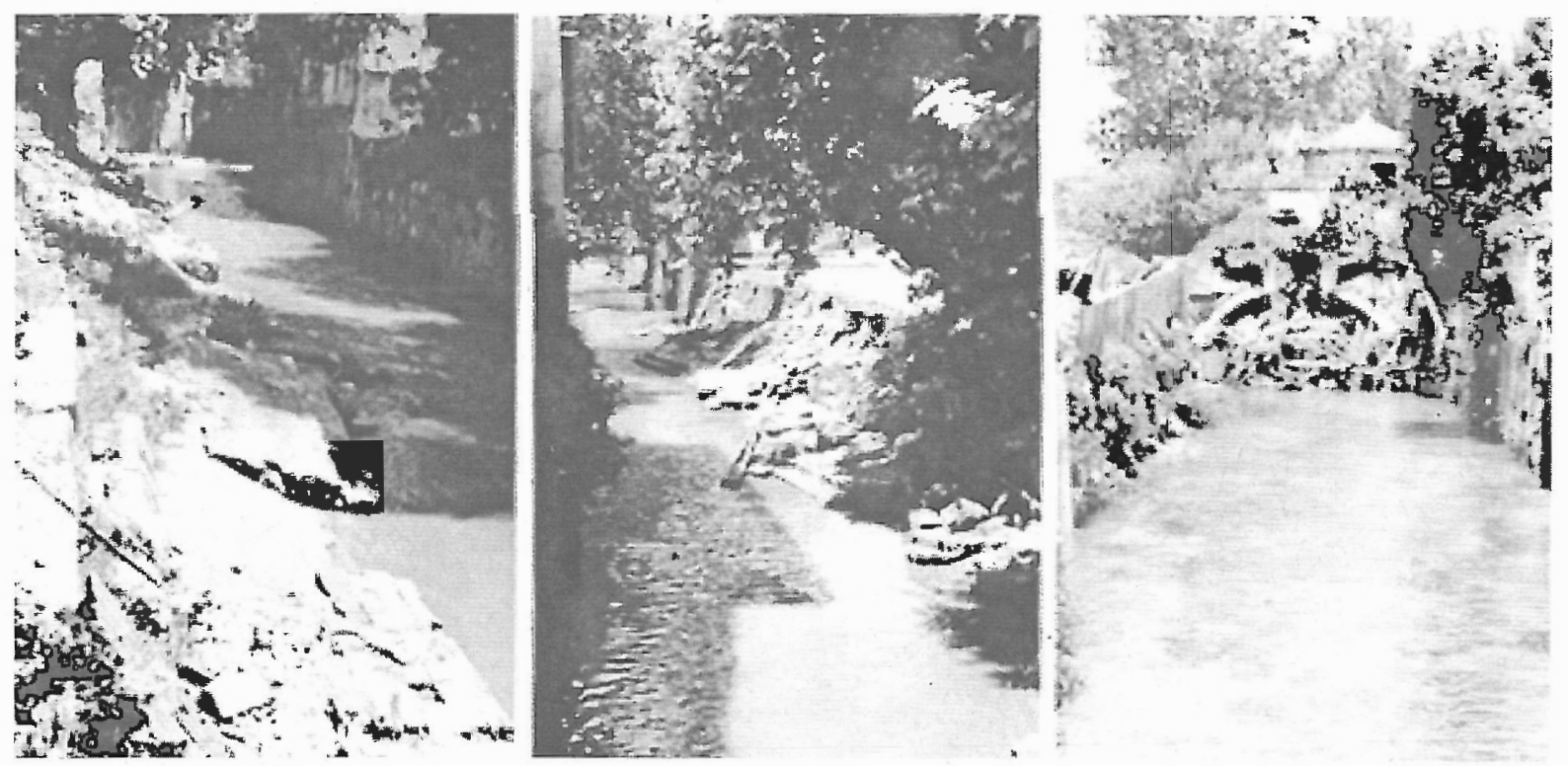

Foto 33 - Efeito das Cheias de 5 de Maio de 2000 (P.TAVARES, 2000).

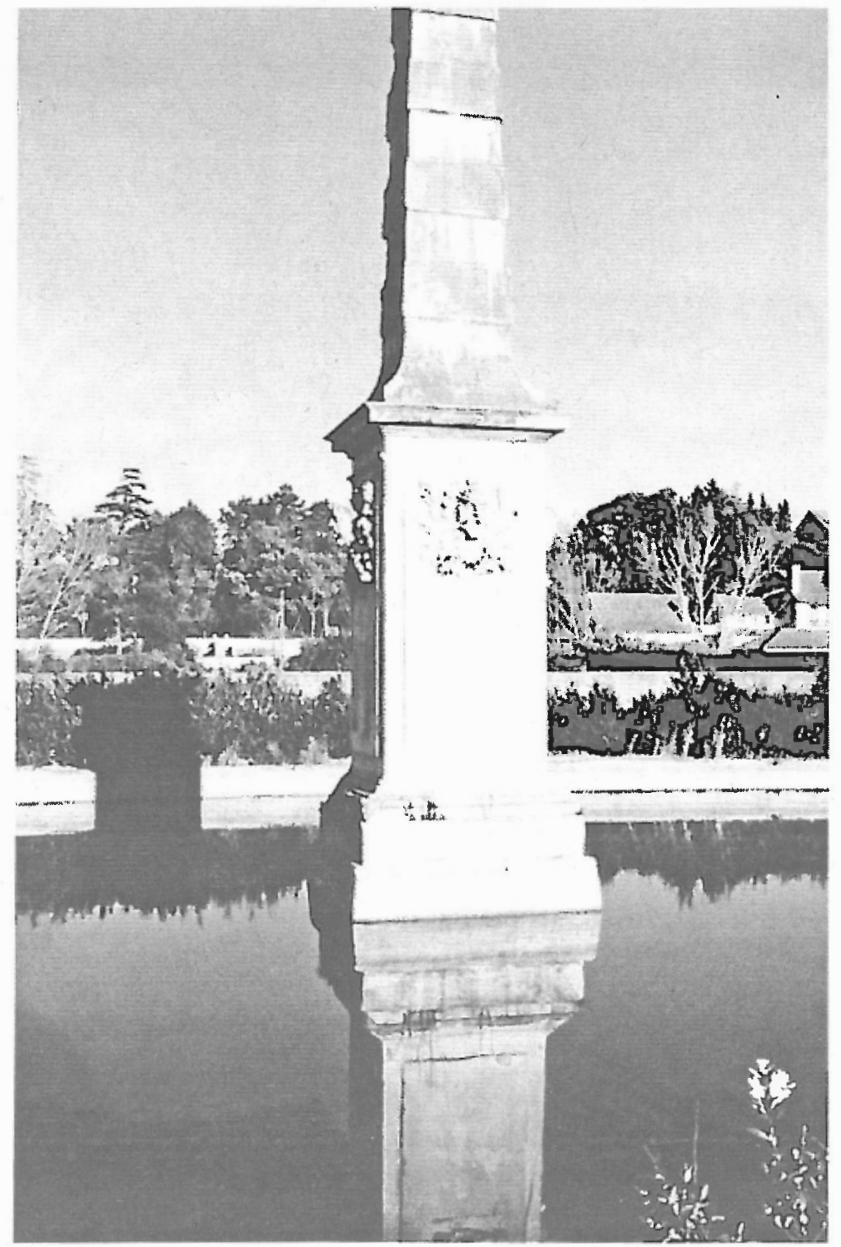

Foto 34 - O belo Obelisco com carrancas e o seu Espelho d'Água, no pano frente à Livraria (P.TAVARES, 1999). 


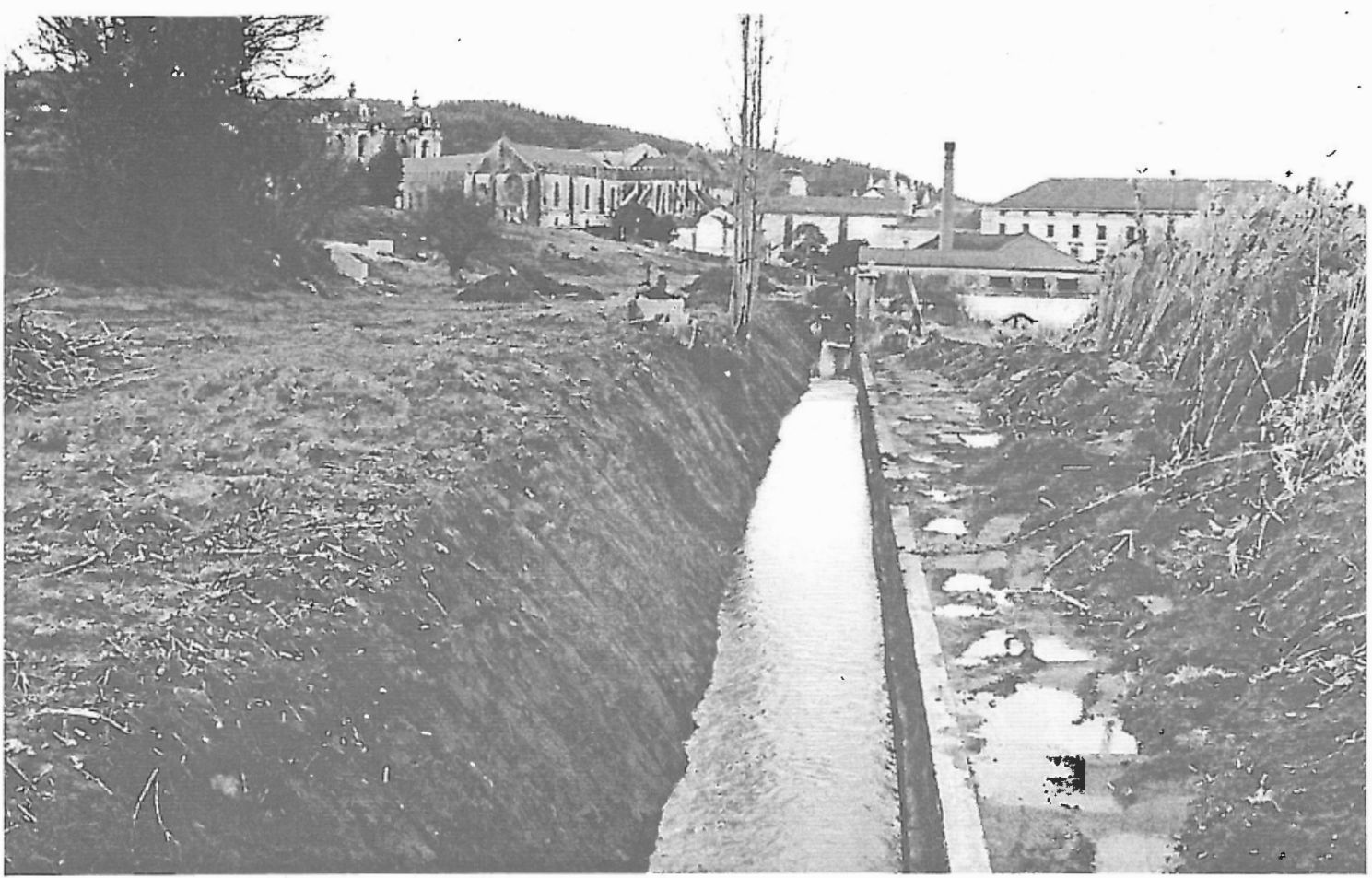

Foto 35 - A Levada a "caminho" do Mosteiro, na direcção da Sacristia, com a "Livraria" à direita. Nota-se o depósito das terras de limpeza (P.TAVARES, 1999).

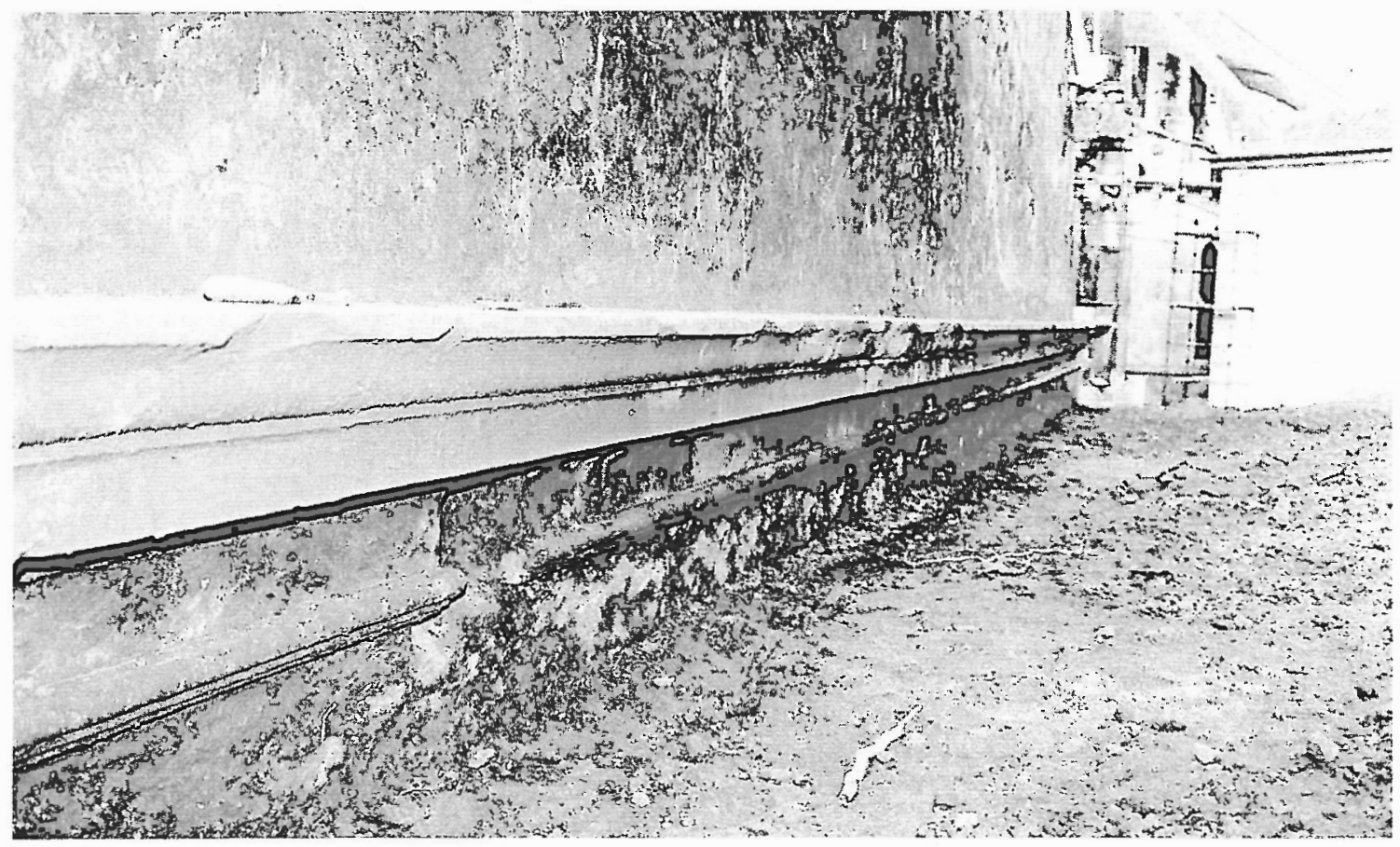

Foto 36 - Friso arquitectónico na Ala Nascente do "Claustro Sul”, frente à Capela do Desterro, recentemente desenterrado e que, a nível de $1^{\circ}$ andar, teria sido concebido para estar a uns $5 \mathrm{~m}$ do solo exterior (P.TAVARES, 1999). 


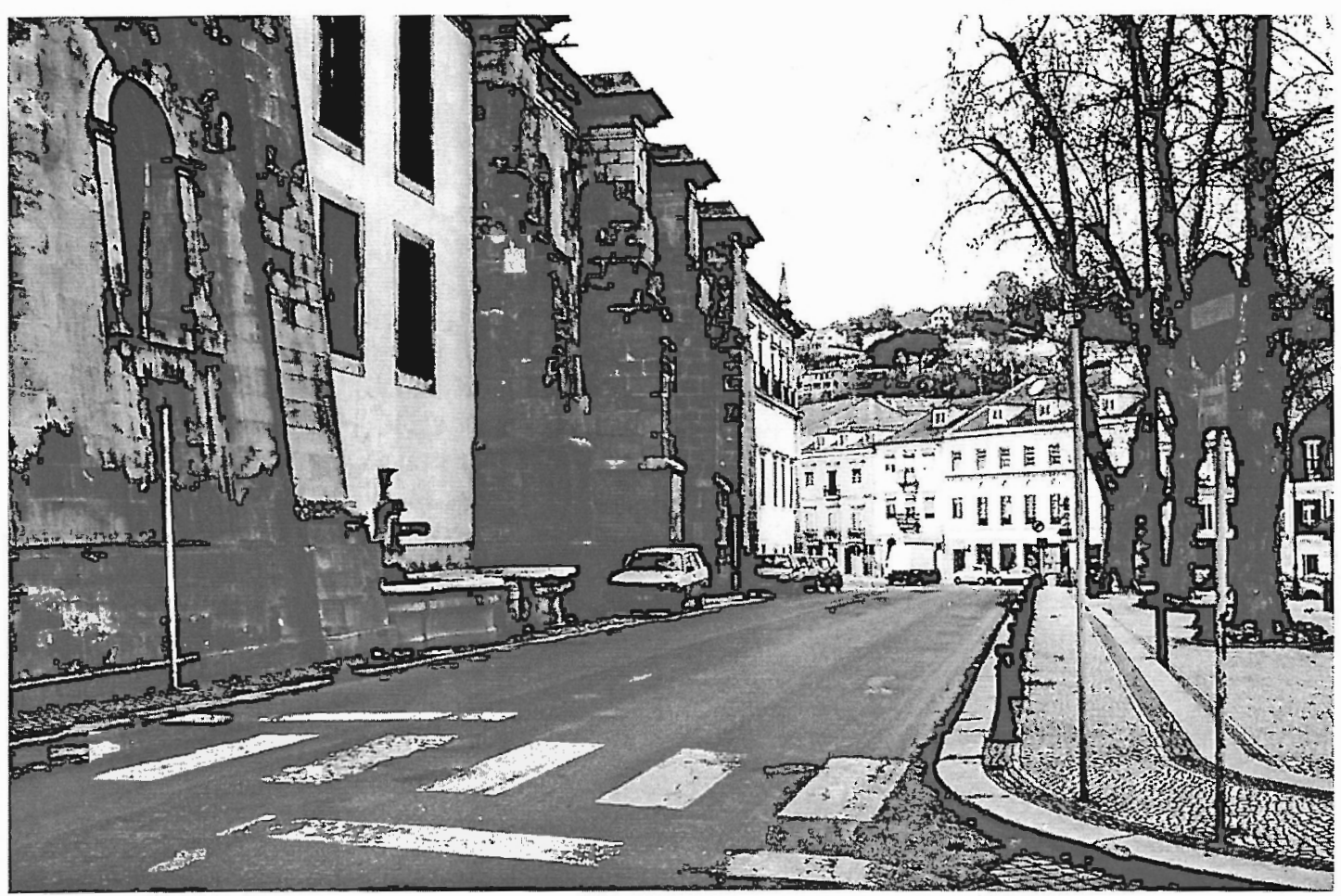

Foto 37 - Alçado Norte parcial do Conjunto Abacial na Praça D. Afonso Henriques ("Quadra Sexta"), vendo-se o Fontanário terminal da Conduta de Água Potável. Neste Alçado consegue-se "ler" em quase toda a sua extensão a marca das cotas anteriores do solo cisterciense. mais altas que as actuais (P.TAVARES, 2000).

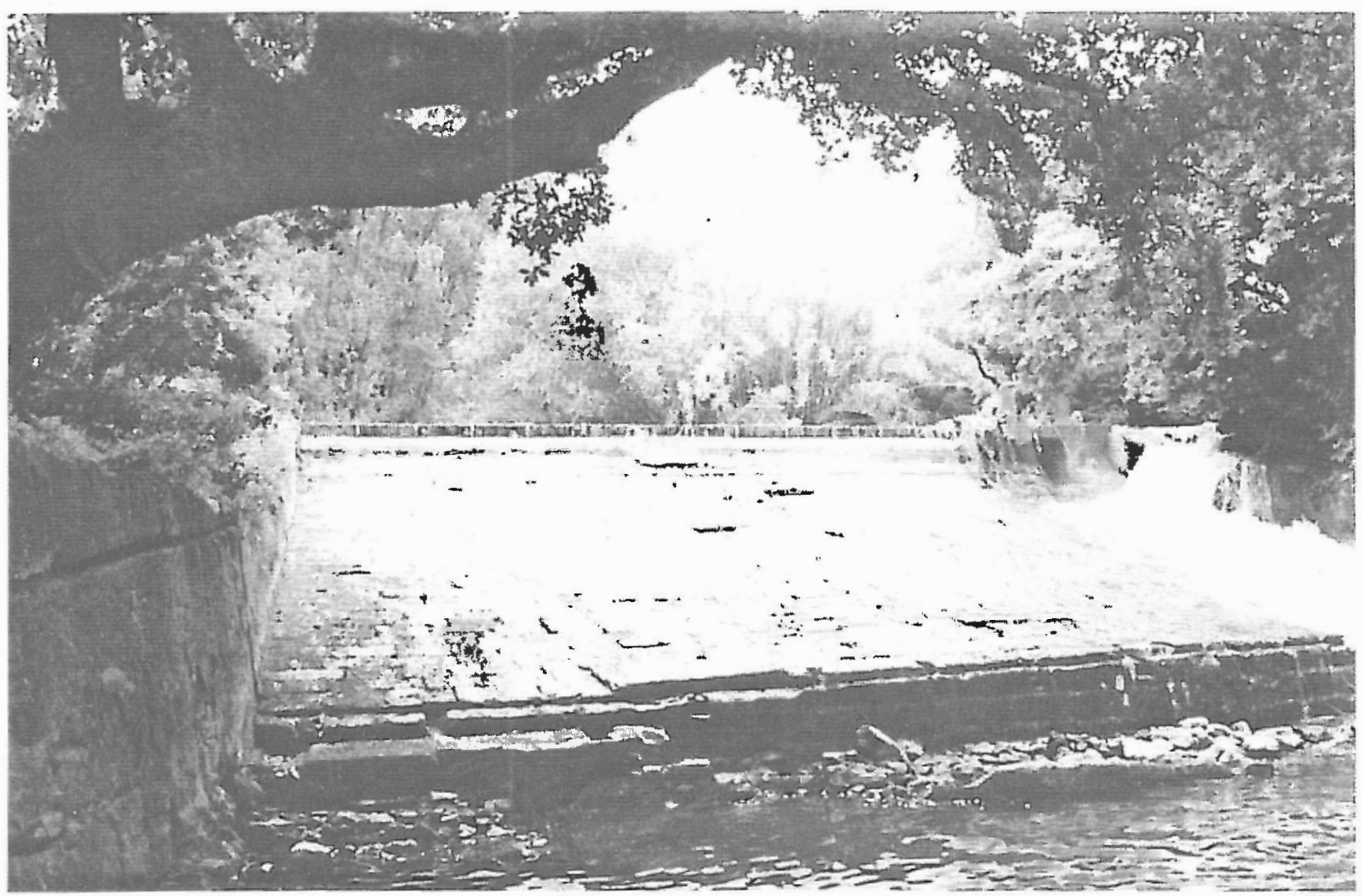

Foto 38 - Açude no Rio Alcobaça, obra impressionante cuja origem remonta ao século XVI, para moinho de papel e para irrigação dos Campos da Maiorga. Foi posteriormente adaptado para produção de energia eléctrica para a já encerrada Fábrica de Fiação e Tecidos. Símbolo de grandeza hidráulica cisterciense e pós-cisterciense, hoje tristemente ao abandono (P.TAVARES, 2000). 
na alteração das necessidades de água, no aumento da incidência das cheias e secas e na subida do nível do mar.

As Cheias são fenómenos estatísticos, que se repetem a lapsos incertos de tempo, mas com probabilidades de frequência e de volume estimáveis. A sua ocorrência tem lugar sempre que a capacidade de escoamento e de infiltração das águas da chuva é excedida pela precipitação, que pode tomar a forma de autêntica "tromba de água", de impacto marcante e concentrado em curto espaço de tempo (digamos, quinze minutos, talvez mais, o que é característico nos Climas Mediterrâneos).

É interessante notar a semelhança entre as cheias do Rio Arno em Florença, Itália e a Alcobaça Cisterciense. Lá, como aqui, as cheias sempre foram um problema premente e persistente. Mas em Florença, cidade mais aberta, foram objecto de registo ao longo dos últimos 800 anos (Losaco, 1967, citado por A.G. BROWN, 1997/2000). Há mapas de cheias de $1333,1740,1844$ e 1966 . Embora estas cheias tenham sido causa de elevados danos patrimoniais e de muita perdas de vida, tais factos não foram impeditivos de Florença se ter tornado numa das cidades mais ricas da Europa.

No fundo, há algo de comparável, nos trajectos da sua história patrimonial e de vida quase que milenária em meio hidro-geoaluvionar, entre a nossa Alcobaça e os seus Rios e a Florença e o Rio Arno. Ambas cidades históricas, ambas de riqueza patrimonial, ambas na sua planície aluvionar,ambas dela (planície aluvionar) beneficiando dos recursos de excepção e ambas dela padecendo o ónus da sua localização, sofrendo cheias, destruições e mortes, mas tudo contribuindo para a sua glória projectada no espaço e no tempo, para a sua teimosia em resistir à adversidade e para a sua determinação em renascer em riqueza acrescida sempre que fustigadas pelas catástrofes.

Uma em cenário de florescimento renascentista, em meio de criação pluri-cultural, a outra em cenário de desenvolvimento Monástico-Cisterciense.

Em.Alcobaça, porém, nota-se o triplo efeito das cheias - inundação, depósitos estranhos e assentamento dos terrenos.

A Água que sobe anormalmente, inundando e molhando, depressa volta a descer e a regressar a leito contido. A bacia hidrográfica que se estrangula em Alcobaça não é como a dos grandes rios internacionais como o Tejo e o Douro ou como a do Mondego. Nestes, as bacias de captação são extensíssimas em área e zonas de precipitação, que acumulam e, quando a água sobe, assim pode permanecer durante dias. Em Alcobaça, porém, a subida de cheia catastrófica pode ser rapidíssima, já que os tempos de escoamento são curtos. A sua probabilidade de ocorrência é bem menor do que nas lezírias do Tejo, já que depende de uma precipitação anormal e concentrada. O efeito surpresa é, porém, bem maior, apesar de a descida também ser rápida.

Mas, acompanhando a inundação, vem a enxurrada, que tudo arranca, arrasta e transporta. Criando rolhões e diques eventuais, verifica-se que, ao quebrarem o ímpeto das águas, as fazem depositar a sua carga. Carga de quatro tipos: de arrastamento, em suspensão, coloidal e também química. Volumes inimagináveis de terras, lamas, calhaus, detritos e lixo são então deixados nas zonas a montante. Como os rios têm forte desvio direccional em Alcobaça e é logo a jusante que se situa o estrangulamento da garganta da Fervença, será em Alcobaça que tenderão a fazer tais depósitos. Como terá sido bem sentido na referida cheia de 1772. Como se sente pelos depósitos surpreendentes, de várias dezenas de milhar de metros cúbicos, alguns retirados do Rossio quase duzentos anos depois, antecedendo a visita da Rainha Isabel II do Reino Unido, na década de cinquenta. Rossio onde sondagens recentes, mandadas executar pela Câmara Municipal para o Programa da "Requalificação Urbana" (Geocontrole, Gabinete de Geotecnia e Topografia, Ld ${ }^{a}$, 2002), revelaram profundidades de terras depositadas e tocadas pelo homem, que chegam a atingir doze metros! (Tal profundidade, também surpreendente, passa-se contudo em zona onde o autor teoriza ter passado o Rio Baça na época do início contrutivo da Abadia, bem frente ao edifício do Gabinete da Universidade de Coimbra em Alcobaça. Trata-se de uma outra história que também será contada).

Fenómeno idêntico terá posto cobro à utilização monástica do Convento de $\mathrm{St}^{\mathrm{a}}$ Clara, em pleno leito de cheia excepcional do Rio Mondego, frente a Coimbra. É impressionante observar a "meia dúzia" de metros de altura de depósitos aluvionares dentro das naves conventuais e o enterramento claustral, recentemente postos a seco através da construção de uma ensecadeira e de complexo sistema de bombagem. Ah! tivesse o génio promotor de então sido Cisterciense, possivelmente outro Santo cantaria !...

Os volumes de terras e os níveis continuadamente em subida, não são só, porém, o resultado das enxurradas e da sua perda da capacidade de carga. Também têm origem na limpeza continuada e persistente e sempre necessária, das várias linhas de água, rios e levadas. Em Alcobaça, todos têm a noção dos volumes que são, retirados periodicamente dos leitos dos rios, devido aos depósitos deixados pelas águas (já que a levada, qual parente pobre e substituível, defïnha em secura convenientemente trocada por apropriação urbana). Até ao século XX, as capacidades de transporte de grandes volumes de terras eram bem mais limitadas e essas limpezas conduziam a que os produtos retirados dos leitos tendessem a ser depositados o mais perto possível. Veja-se, como exemplo, o nível do outrora 


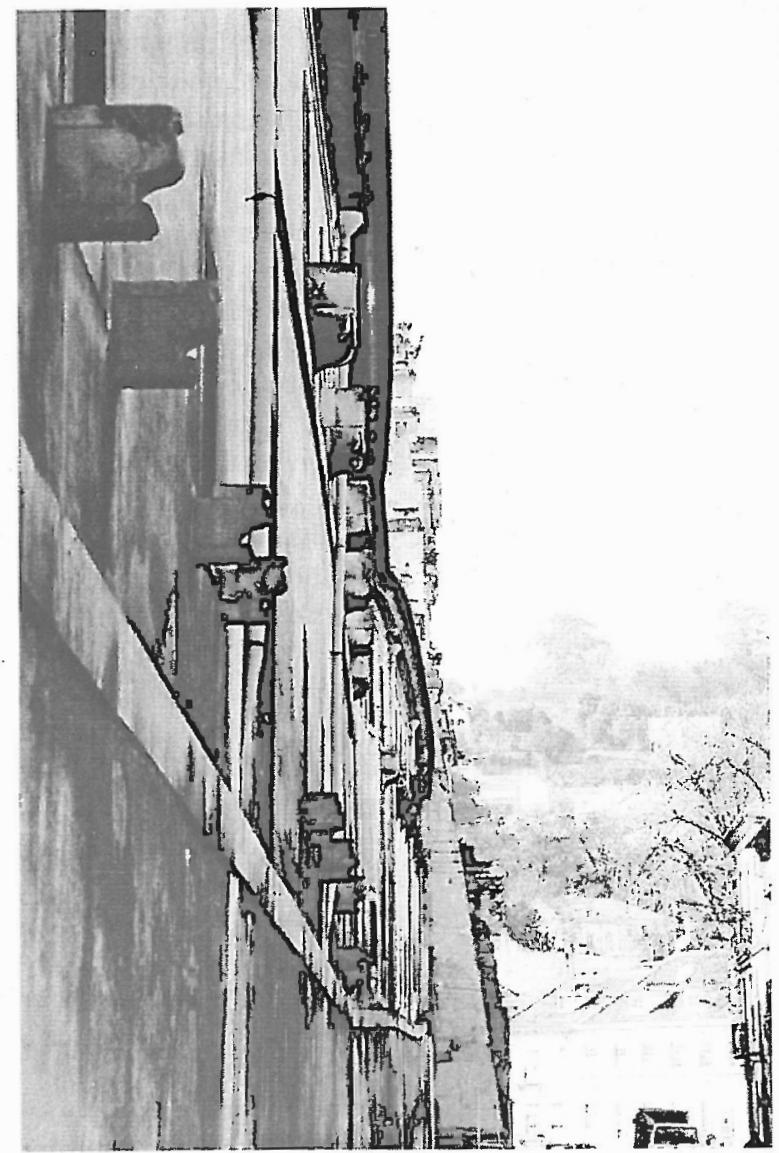

Foto 39 - Deslocamentos tridimensionais no Alçado Norte dos Claustros do Cardeal e do Rachadouro (Rua D. Pedro V), ocasionados por assentamentos no edificado em virtude de empapamento dos solos ocasionado pelas cheias (P.TAVARES, 1999).

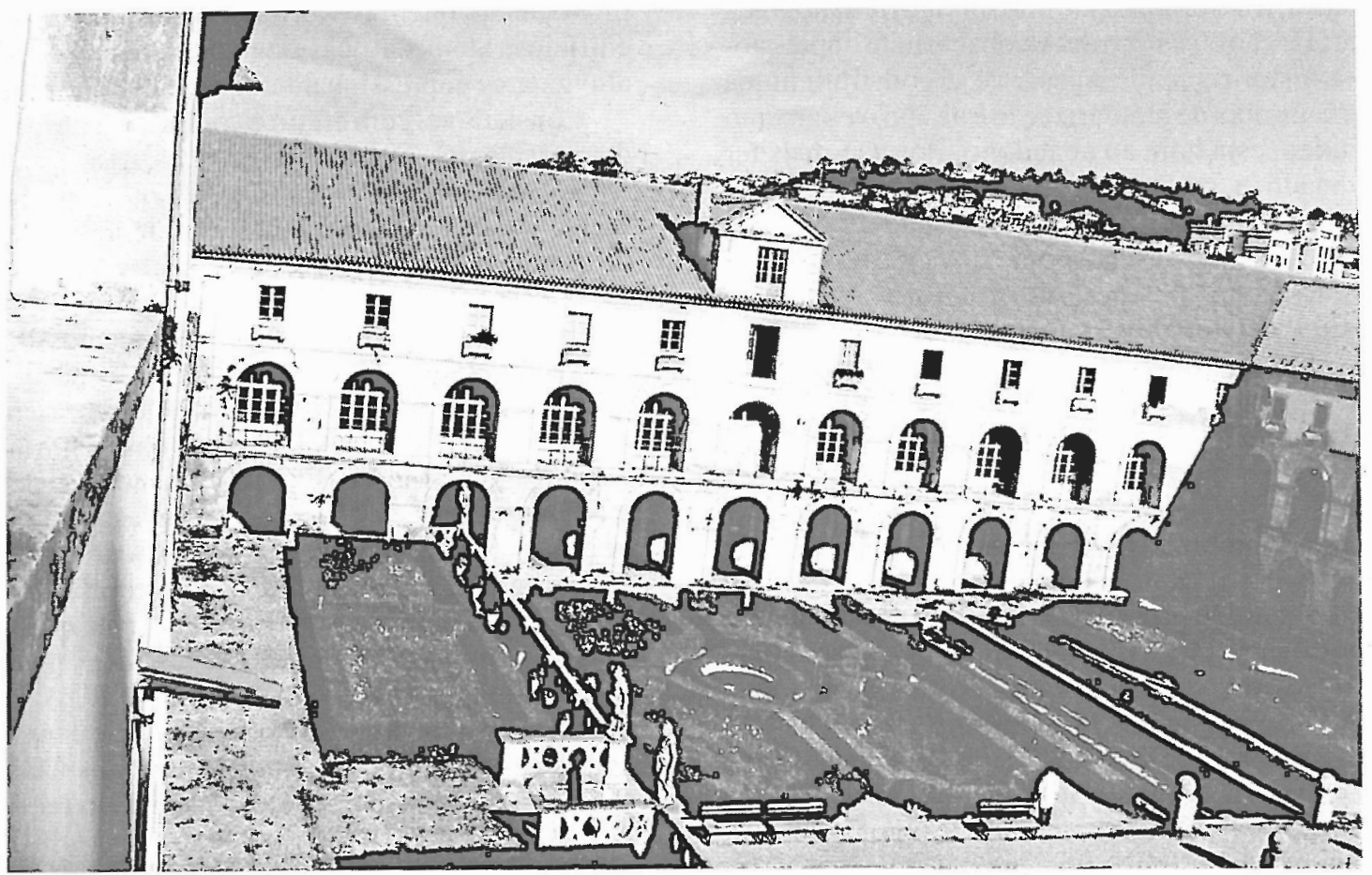

Foto 40 - Alçado Sul da "Livraria" do Mosteiro de Alcobaça (P.TAVARES, 1999). 
belo Jardim frente à "Livraria", com o seu amplo espelho de água, tanque de formato elíptico em cantaria com uma capacidade de armazenamento rondando os seiscentos e vinte mil litros de água e com um majestoso obelisco central, dotado de quatro carrancas de água esculpidas em rico relevo em pedra calcárea, orientadas segundo os eixos principais da elipse e também linhas preferenciais do Sistema Hidráulico na "Cerca". A cota geral circundante apresenta-se hoje subida mais de meio metro em relação à cota do séc.XVIII para que foi concebida a vasta plataforma ajardinada onde se situa o grandioso e formoso tanque.

Por diversas vezes, no século XIX e no século $\mathrm{XX}$, ida a sabedoria e a memória cisterciense, assistiu-se a amplos recondicionamentos e remoções de terras no Rossio e nas zonas circundantes do Mosteiro (em 1839, 1872, 1909, 1951 e 1956, conforme fontes diversas, em particular B. VILLA NOVA, 1940). É o "sobe-e-desce" de Alcobaça! O início do séc.XXI prepara agora a próxima mexida, com a "Requalificação Urbana" de Alcobaça.

De referir ainda o belo Açude na garganta da Fervença, obra iniciada no séc. XVI e aforada ao irmão de Damião de Góis para fabrico de papel (não o primeiro papel a ser fabricado em Portugal, mas o primeiro a ter Marca d'Água, como nos transmite o Prof. Aires Nascimento) e para rega dos Campos da Maiorga, séculos mais tarde adaptado para produção de energia eléctrica por transformação de energia hidráulica, fruto do engenho e ao serviço da malograda Fábrica Fiação e Tecidos de Alcobaça. Este impressionante e histórico açude, apesar de se constituir numa importante obra de regularização e de aproveitamento hidráulico, está hoje ao abandono. Por não mais ter funcionado a comporta de "descarga de fundo" (supomos que desde algures na década de noventa passada), o notável açude apresenta-se hoje quase que completamente cheio dos referidos resíduos e depósitos aluvionares, que ficam ali grandemente retidos. Situação que também começará a ser perigosa, já que, lenta mas inexoravelmente, vai enchendo o leito para montante e subindo as cotas do rio.

\section{Assentamentos Diferenciais}

Falta contudo referenciar a terceira consequência calamitosa das cheias, quiçá a mais onerosa, dados os estragos vultuosos que causa no edificado: tratase dos "Assentamentos Diferenciais".

"Assentamento Diferencial", em Construção Civil, representa o abatimento de parte do edificado em relação a outra parte do mesmo edificado, geralmente causado por mau funcionamento das fundações ou por desigual comportamento dos terrenos de fundação.
O "empapamento" prolongado das solos não devidamente compactados, pode ocasionar assentamentos substanciais das camadas de fundação e o consequente abatimento das construções que nelas fundam.

A compactação devida dos solos baseia-se em quatro factores principais: natureza dos materiais a compactar, sua granulometria, condições de humidade e meios e processos utilizados na execução. A eficiente conjugação destes factores é ciência recente do domínio da Mecânica dos Solos. É natural que, apesar de todo o empenho e sabedoria construtiva Cisterciense, a grandeza e a extensão das movimentações de terras se tenham revelado altamente penalizantes, quando anormalmente solicitadas. A partir do séc.XVI e do tempo dos Cardeais Príncipes e Comendatários de Alcobaça e de todo o fervor construtivo dos séculos seguintes, como refere D. Maur de COCHERIL (1983), a necessidade construtiva levou à deslocação e re-implantação do Rio Alcoa, de modo a permitir o lançamento de, pelo menos, mais dois Claustros: o Claustro do Cardeal e o mais jovem Claustro do Rachadouro (da Biblioteca).

Deste modo, a grande cheia referida de 1772 apanhou esse processo e, ensopando completa e demoradamente de água todos esses terrenos mexidos numa amplitude ainda nunca alcançada, causou estragos de magnitude catastrófica em muitas das instalações monásticas, com especial incidência nos Claustros referidos, em extensões e expressões significativas, provocando quebras, torturas e desfasamentos de edifícios, além de ocasionar certamente depósitos aluvionares impressionantes, que houve que remover.

Constata-se, com efeito e após atenta observação dos paramentos, alçados, pavimentos, frisos, cimalhas e diversos outros pormenores Arquitectónicos, que houve lugar a "Assentamentos Diferenciais" brutais de grande parte das estruturas construidas, ou ainda em construção, nos Claustros referidos.

Genericamente, existiram assentamentos diferenciais importantes, ocasionados pela cedência dos terrenos de fundação, sobretudo em bandas orientadas pela direcção preferencial das Linhas Hidráulicas originais, elas próprias paralelas às bancadas rochosas erodidas presentes no sub-solo. Esses assentamentos, bem detectados e orientados, provocaram tensões elevadas no conjunto edificado dos dois Claustros que, devido à sua grande inércia de conjunto, quebraram e assentaram segundo padrões que se podem interpretar (o que também será alvo de outro trabalho).

Observando, por exemplo, o friso em cantaria de pedra a meia altura do Alçado Norte dos Claustros do Cardeal e do Rachadouro, virado para a Rua D. Pedro V, nota-se que o seu desenvolvimento é claramente "ondulado" tridimensionalmente, quer no Plano Vertical, quer em Planta, estando longe do 
Foto 41 - Exemplo de Quebra Claustral, neste caso no Alçado Norte da Ala Sul do Claustro do Cardeal. No outro lado foi edificado grosso botaréu de contenção entre esta zona e a Sacristia Manuelina (P.TAVARES, 1999).
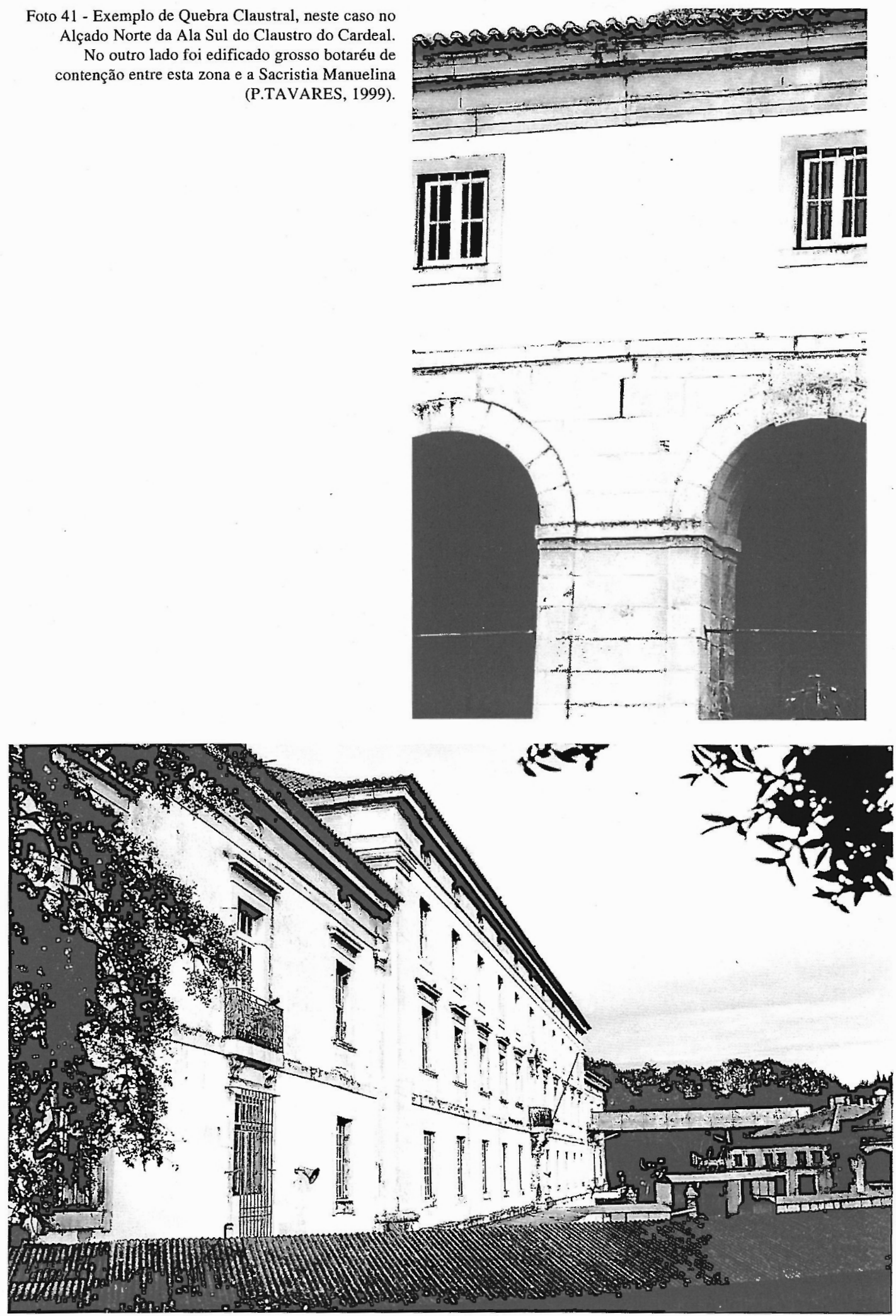

Foto 42 - Alçado Sul da "Livraria" do Mosteiro de Alcobaça (P.TAVARES, 1999). 


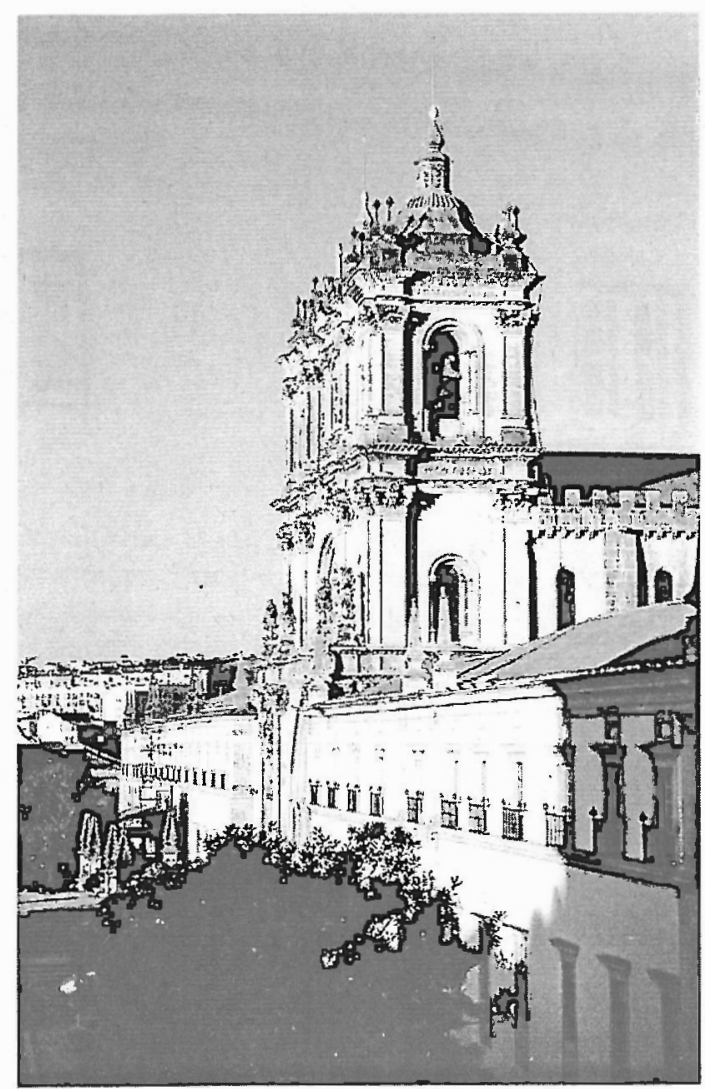

Foto 43 - O longo Alçado Principal Poente, em foto razante, notando-se no friso e cimalha em pedra ao fundo, no topo Norte da Ala Norte (Palácio Abacial), o afundamento construtivo na aproximação ao Rio Baça e que atinge $42 \mathrm{~cm}$ (P.TAVARES, 1999).

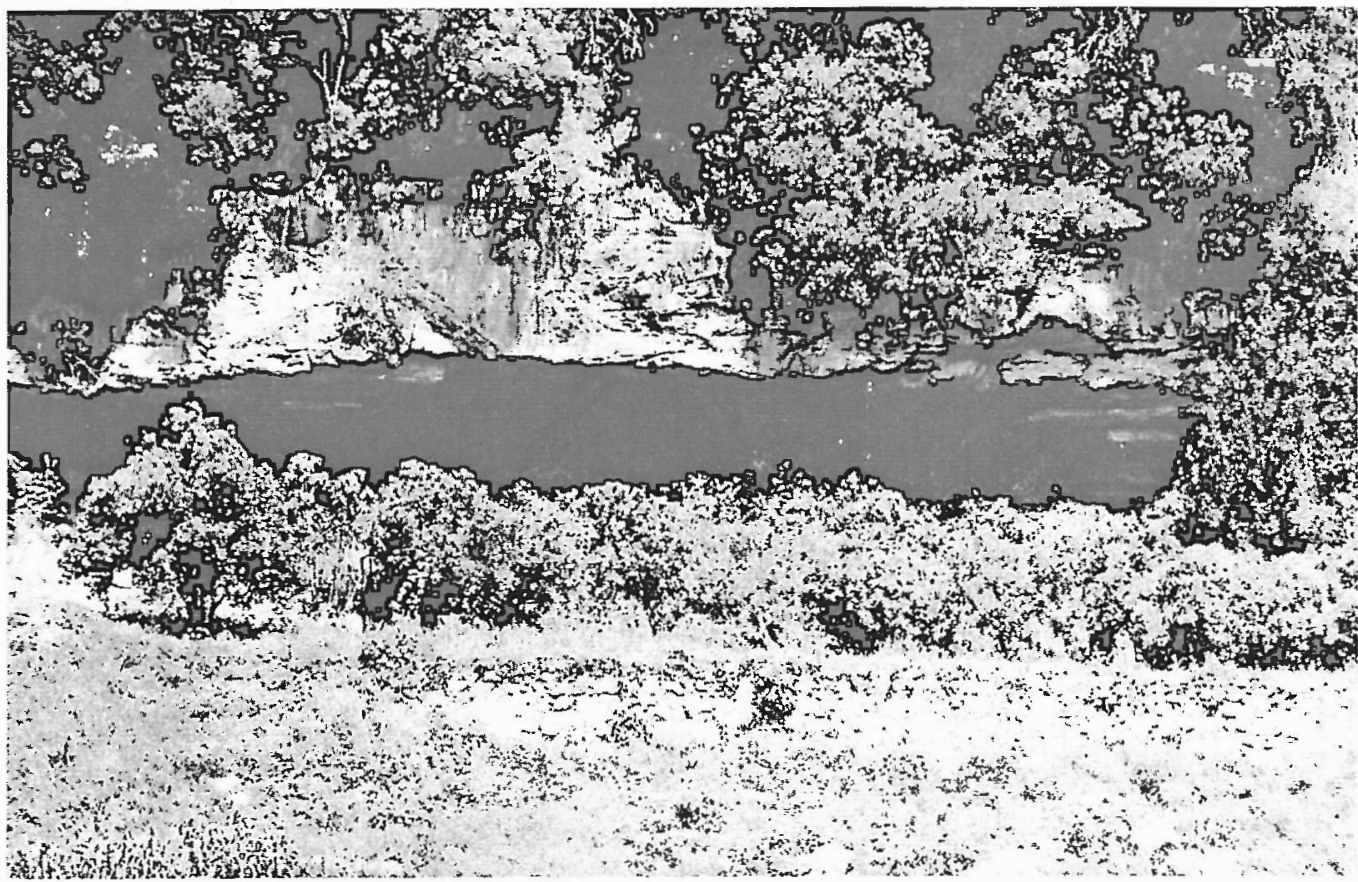

Foto 44 - Estrato Rochoso de grés (vulgo "piçarra") de possança e visibilidade apreciáveis, junto à margem esquerda do Rio Baça, no talude fronteiro à Estrada Nacional que vem das Caldas da Rainha, na última curva antes de se entrar em Alcobaça. Este exemplo que é possível observar "no exterior", dá uma ideia do que tambem se passa no sub-solo, onde vales profundos e abrutos a nível rochoso criados pela acção da erosão (glaciação, acção das águas, do vento, da vegetação e de outros seres vivos), estão "escondidos" por milénios de anos de depósitos aluvionares, resultado da acção persistentes de cheias, que lavam, retiram, transportam e depositam (P.TAVARES, 1999). 
alinhamento recto e horizontal com que deve ter sido concebido.

Outro local onde o assentamento diferencial pode facilmente ser observado é nos pequenos troços de Alçado Sul, a Nascente e a Poente do grande corpo da Biblioteca ("Livraria" na terminologia Cisterciense e prudentemente içada para cotas dos pisos superiores). Com efeito, neste Alçado, no troço a Nascente, o friso de remate superior está claramente abatido e descendente para o lado da Biblioteca e os vãos janela estão nitidamente inclinados.

Certamente que esta catástrofe tripla, inundação, depósito de terras e ruina arquitectónica em seguimento de assentamentos diferenciais, há-de ter tido consequências gravosas enormes e ocasionado obras e acções de recuperação de monta.

Extraordinariamente, a Ala da grande e nova Biblioteca Cisterciense, o espaço sem qualquer apoio intermédio mais amplo de todo o Conjunto Monumental Cisterciense (dimensões úteis internas da Livraria de $47,70 \times 12,70 \mathrm{~m}$ ), terá resistido a esta prova de força por duas razões: primeiro, porque foi ajudada pela contenção proporcionada pela complexa e notável estrutura de madeira da cobertura (que lhe conferiu a necessária rigidez de conjunto, ao mesmo tempo aliada a uma certa flexibilidade contida de deformação) e, segundo, porque "assentou em bloco".

Istoé, a Biblioteca teve a "sorte" de estar localizada por inteiro na referida "banda de assentamento", pelo que, apesar das suas grandes dimensões, pôde-se "afundar" só com quebras laterais (razão porque, hoje, para se entrar na Biblioteca, há que descer uma pequena rampa que vence esse desnível ocasionado pela quebra por assentamento). Pode-se adiantar que, em termos de Engenharia Civil, este assentamento foi de proporções quase que inacreditáveis, atingindo valores da ordem de dois metros. O bonito pavimento do Salão da Biblioteca (executado principalmente em pedra calcária rija de policromias contrastantes, origens diversas e desenhos geométricos variados) foi certamente reperfilado através do carrego das abóbadas inferiores, constituindo um plano quase que perfeito, embora inclinado. Actualmente, entre extremos do Salão da Biblioteca, regista-se um desnível superior a meio metro. Já o corredor que Ihe é paralelo, a Norte e onde se localiza a bonita porta central de acesso principal à Biblioteca, apresenta desniveis actuais bem superiores.

Não é só aqui que se observam assentamentos de monta nos edifícios abaciais. Toda a zona Norte-Poente, englobando o Refeitório e o Palácio Abacial, inciuindo o actual Claustro dito de D. Afonso VI, também sofreu assentamentos consideráveis, devido a pior natureza geológica das camadas de fundação. No Alçado Norte do Palácio Abacial tal já não se nota, devido às correcções introduzidas ao longo de muitas intervenções profundas de ocupação e da construção civil correlacionada. No Refeitório, porém, denota-se uma clara inclinação das estruturas, com uma ilusão de óptica interessante. Para quem entra no Refeitório vindo do Claustro, o pavimento parece claramente inclinado para Nascente, encimado por uma estrutura, colunas e paredes, aparentemente verticais. Mas, na realidade, é o pavimento que está de nível (foi rebaixado, recolocado e reperfilado na horizontal na década de trinta passada, pelos Monumentos Nacionais, após o desmantelamento do Teatro Municipal que, durante 90 anos ocupou aquele espaço), sendo antes a superestrutura que está francamente inclinada para Poente!

É interessante notar que, em plena Idade Média, na época de maior expansão Cisterciense, no séc. XII e também no XIII, onde a intenção de edificação era construir em definitivo e para todas as gerações vindouras, mas onde as técnicas e meios eram limitados, compensavam os Cisterciense através da utilização de materiais resistentes e perduráveis e em condições de estabilidade de fundação. Éassim que, em Alcobaça, se nota que toda a parte mais nobre que nos chega da Idade Média (Naves da Igreja e Transeptos, Claustro do Silêncio e corpo das Salas do Capítulo, Sala dos Monges e Dormitório Medieval), fundava directamente em estratos da rocha de grés subjacentes (vulgo "piçarra"), pelo que resistiu bem às cheias e mais moderadamente a terramotos. Nas naves colaterais do Mosteiro podem-se observar certas diferenças de cotas na espessura das paredes e desfasamentos entre pilares/colunas/colunelos e que têm sido alvo de teorias elaboradas por estudiosos diversos, atribuindo-as nomeadamente a diferentes fases construtivas da Abadia (Alcobaça I, Alcobaça II - M. COCHERIL, 1989) ou a eventuais diferentes "Mestres de Obras". Na opinião do autor, tais singularidades não são mais do que reforços introduzidos nas estruturas, devido a deslocamentos e ruinas resultantes de acções sísmicas, sendo "disfarçados" pelos quatro altares edificados naquela zona e também descritos por Cocheril.

Já as partes medievas de menor prestígio (por exemplo, a Ala dos Conversos), sucumbiram, entre outras razões, pela deficiente ou mais profunda fundação. e a sua consequente maior fragilidade. Quanto aos amplos e soberbos Claustros edificados na Idade Moderna, aparentemente dominando outras técnicas construtivas e recorrendo quer a "Arquitectos" eventualmente externos e contratados, quer a uma "mão de obra" mais dispendiosa, foram arrojados na concepção mas descuidaram a coerência e a estabilidade de fundação, facto de que se vieram a ressentir e bem.

Nãoé assim de estranhar que, nas zonas construtivas Medievais que hoje nos chegam, se notem mais os efeitos dos Terramotos e que nas zonas posteriores da Idade Moderna sejam mais marcantes os efeitos das Cheias a das calamidades correlacionadas. 
territorium $\quad 10.2003$

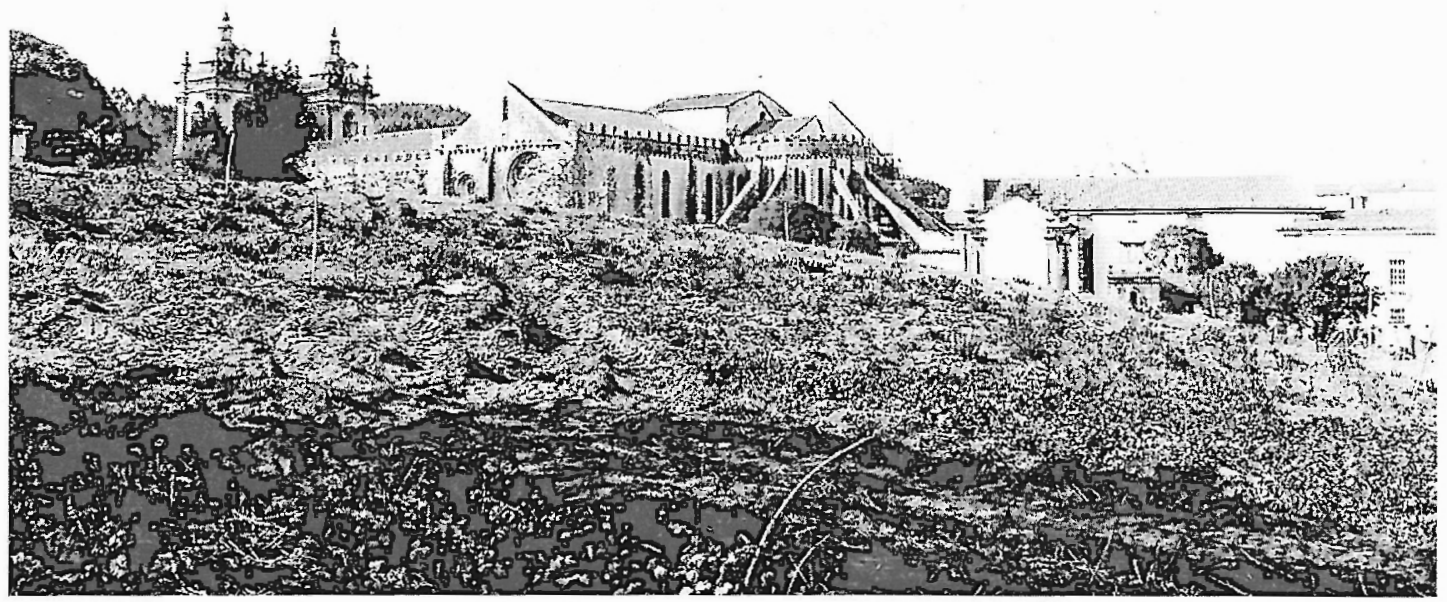

Foto 45 - Alçado Sul parcial do Mosteiro de Alcobaça, Transepto Sul, Arcos Botantes, Capela do Desterro e Sacristia (P.TAVARES, 1999).

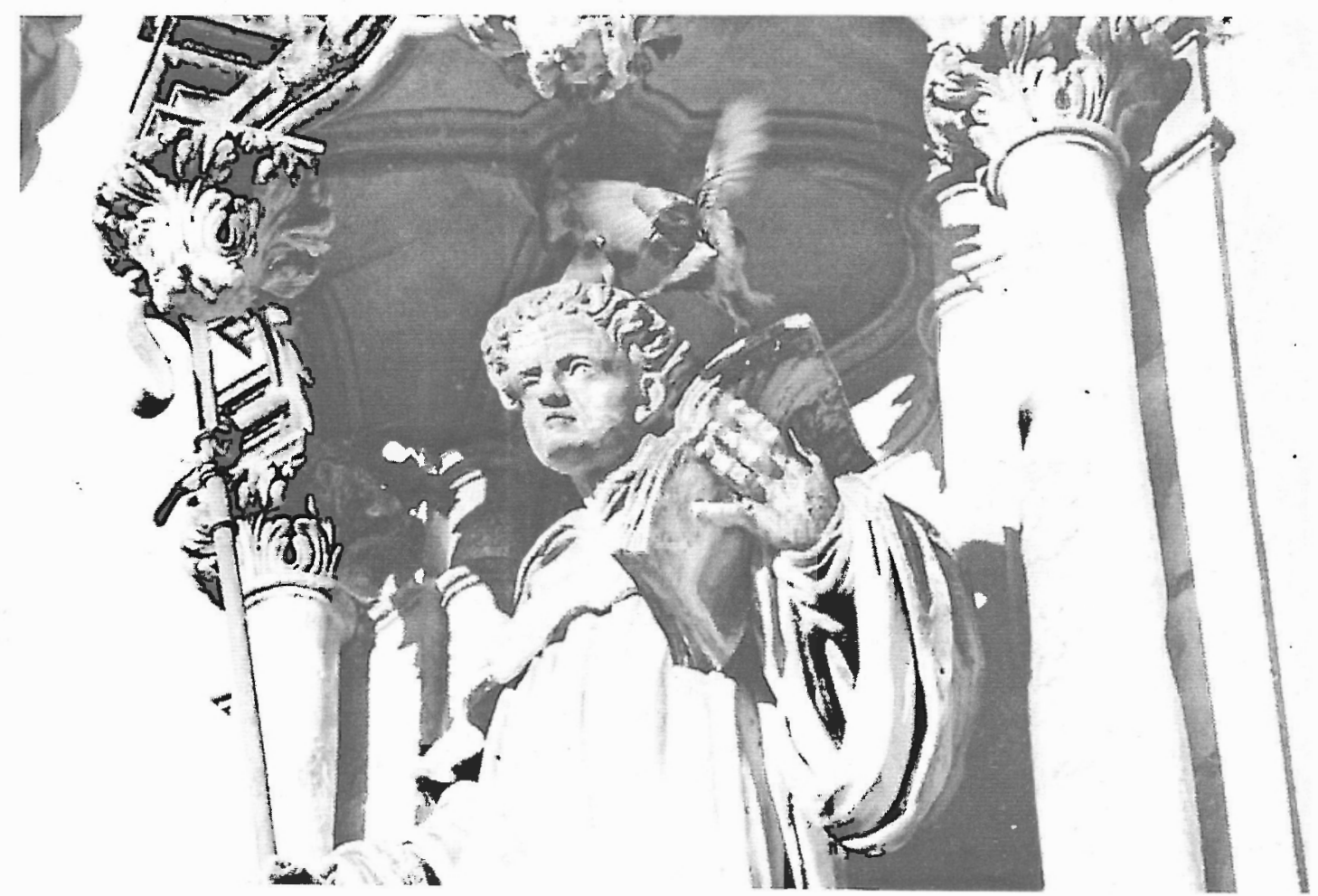

Foto 46 - S.Bernardo pensativo, no Alçado Ponte Principal, do início do séc.XVIII (P.TAVARES, 1999). 
Foto 47 - Vista Aérea do Conjunto

Monumental, com o Sol bem a Sul, o casario circundante e expectante, e

Alcobaça fervilhando em Domingo de Feira. 2000
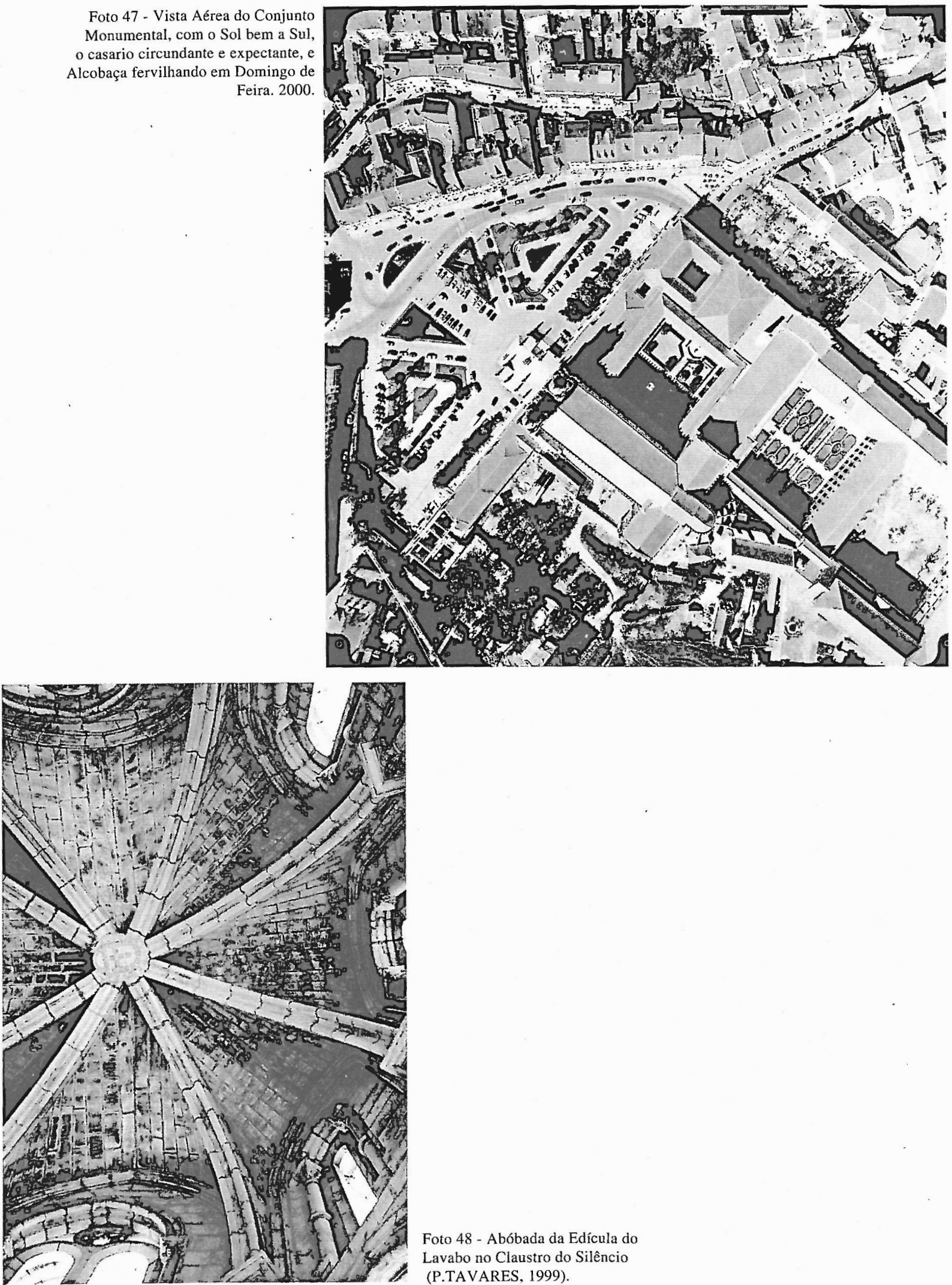

Foto 48 - Abóbada da Edícula do

Lavabo no Claustro do Silêncio

(P.TAVARES, 1999). 


\section{Epílogo. O Oculto e o Fantástico}

Já se referiram as "maldições" de S. Bernardo. Essas eram para fora, para Terceiros. Mas também as houve para dentro, para a Ordem.

OMosteiro (Naves, Transepto e Deambulatório), para além do Altar-mor, desfrutava de 17 outros altares (cujos patronos variaram ao longo do tempo). Dezassete é esse "número primo" que perseguiu os Cistercienses em Alcobaça. Com efeito, constata-se que, no perto de um século de final de vida Cisterciense em Alcobaça, houve um ciclo de 17 anos que deixou a sua "marca nefasta":

- Terramoto em 1755 ,

- 17 anos depois, a grande cheia de 1772 ,

- 17 anos depois, a Revolução Francesa de 1789, que extinguiu a Ordem em França em 1790 e que viria a ocasionartambém, emúltima instância, a sua queda em Portugal,

- 17 anos depois, o início das Invasões Francesas em 1808, que culminaria em 1811 com os desacatos e incêndios referidos no Mosteiro,

- 17 anos depois, o início da Guerra Civil em 1828 , que cuIminaria com a fuga da comunidade monástica em 1833 e a extinção da Ordem em 1834.

Desde a Carta de Fundação em 1153 até à fuga dos monges Cistercienses de Alcobaça em 1833, decorreram 680 anos, ou seja, 40 vezes 17 ! Desde a Sagração do Mosteiro em 1252 até à extinção da Ordem em Portugal em 1834, decorreram 612 anos, ou seja, 36 vezes 17 !

"Não acredito em Bruxas, mas que as há, há" diria Frederico Garcia Lorca.

No entanto, esta aparente regularidade não é de estranhar em demasia. Os ciclos são Biológicos, estãona Natureza, fazem parte da História, pertencem à condição Humana.

Caso contrário, que dizer então deste biénio de múltiplas celebrações (Outubro 2002 a Maio 2004)? Periodo de pouco mais de ano e meio, em que ocorrem os 850 anos da Fundação e os 850 anos do "Trânsito" de S. Bernardo, ambos os factos de 1153, os 780 anos da instalação dos Monges no Mosteiro de Alcobaça em 1223, os 750 anos da Sagração da Igreja Abacial em 1252, os 170 anos do abandono pelos Cistercienses e da ocupação popular em 1833 e do Decreto de Extinção de 1834.

Seria então surpreendente notar que desde o ano de 1153 da Fundação e do "Trânsito" de S. Bernardo e até ao presente ano de 2003, decorreram precisamente 50 vezes 17 anos! Bem como os 170 anos que decorrem desde o abandono do Mosteiro pelos Cistercienses em fuga e da ocupação popular em 1833 , correspondem a 10 vezes 17 anos! Ese dividirmos ao meio o ciclo referido de 50 vezes 17 anos, ou seja
25 vezes 17 anos desde a Carta de Fundação e outro tanto para chegarmos ao presente, caímos, nesse meio, mesmo em cima do que foi o maior desastre nacional e que conduziu à dominação pelo Rei estrangeiro: a Batalha de Alcácer-Quibir em 1578 (D. Sebastião viveu periodos no Mosteiro de Alcobaça, ao cuidado de seu Tio-Avô e Abade Comendatário de Alcobaça, o Cardeal D.Henrique).

Mais do que o aspecto do Fantástico (que é inegável em certos fenómenos e/ou catástrofes da Natureza), da superstição, aviso ou castigo superior (que tiveram a sua época), ou da resignação aos factores imponderáveis das Leis da Mãe Natura ou do Poder do Divino, há que encarar a problemática inerente aos "Riscos Naturais" com pragmatismo e bom senso.

\section{Conclusão}

É gratificante constatar a recente riqueza de produção legislativa portuguesa no domínio đa gestão das Bacias Hidrográficas. Estes Diplomas legais têm, ao longo de poucos meses, coberto a quase totalidade do território nacional.

A sua aplicação ao longo do território nacional é, porém, deveras heterogénea e o seu reflexo nos PDM-Planos Directores Municipais é, genericamente, insufuciente. A obrigatoriedade legal dos PDM's, a rapidez com que foram executados, o "conforto" que proporcionam como instrumentos de Planeamento e a tramitação requerida para a sua modificação (legal, técnica, administrativa, política e psicológica das Populações), leva a que aqueles instrumentos de Planeamento, que são afinal o estado último do controlo operacional do Planeamento Físico, estejam geralmente desajustados e se prolonguem como tal. Salvo honrosas excepções, houve lugar a muitos atropelos ambientais e de simples "bom senso", tudo na era em que o progresso técnico rápido, a melhoria económica conseguida, a estrutura social evoluida e a sociedade de informação actuante, permitem alimentar a ilusão de que tudo se controla e tudo se obtém!

Este é só um exemplo. A Segurança está hoje legislada "por todos os lados". Na Arquitectura, na Engenharia, nos Transportes, nos aspectós Sociais, Jurídicos e Administrativos, na Criança, no Adulto, no Idoso e no Inválido, no Trabalho e no Lazer, desde nossas casas aos demais Edifícios, na Biologia, na Medicina, no que comemos e no que respiramos.

No entanto, não há técnicas, legislação ou modelos possiveis que garantam o bem estar absoluto e a segurança total.

Tal como na era Cisterciense, bem como o já tinha sido no Mundo Romano, nas Civilizações da Ásia Menor, ou no apogeu Egípcio, é necessário 
haver a filosofia e a estratégia, a formação e a preparação, a vontade de as implementar e a capacidade de o fazer. A democratização das Sociedades, levando à substituição da força pela razão, da dominação pela liberdade, só consegue alcançar verdadeiro sucesso ao primar pela educação, pela formação e pela informação.

Os modelos Climáticos e os Sistemas hidrológico-fluviais são só semi-previsíveis, pelo que há que ter a maior cautela na generalização de tendências. A própria capacidade do género humano para tolerar mudanças éapreciável, mas não pode ser subestimada.

A natureza evolutiva dos riscos ambientais e a diversidade dos factores sociais que podem ser responsáveis pela reacção humana, aparecem ilustrados quer nos registos arqueológicos, quer nos históricos. Ambos mostram, inequivocamente, que nunca houve, nem nunca haverá no futuro, uma resposta única e determinística para um conjunto de parâmetros ambientais (A.G. BROWN, 1997/2000).

Já dizia John Kennedy, quando Presidente dos EUA, que "quem conseguir resolver os problemas da Água é merecedor de dois Prémios Nobel: $\mathrm{O}$ da Paz e o da Ciência" (J.M. BAPTISTA, 2002).

Descendo mais uma vez do conceito generalista à realidade de Alcobaça, realçam-se o somatório de causas e de efeitos, e a importância dos factores Climáticos, Hidrológicos, Geológicos, Históricos e Urbanísticos em Alcobaça e a situação "duplamente única" que, para o bem e para o mal, caracteriza Alcobaça (Património Cisterciense de excepção, rodeado por uma cidade e sensibilidade invulgar às cheias).

Todos os eventos de Risco referenciados na Alcobaça Cisterciense parecem idos e perdidos na poeira da História e nos nevoeiros da Memória.

Mas, reparando bem, são hoje tão ou mais actuais que então, atendendo à probabilidade continuada das suas ocorrências, com algumas versões actualizadas pertinentes (epidemia biológica, desastres ambientais, desastres nucleares) e motivando o claro empenho dos Governantes, das Autoridades, dos Planeadores, da Media e das Populações.

As Técnicas de previsão, de emergência e de combate à calamidade são hoje de conhecimentos e meios substancialmente maiores, mas também são maiores as concentrações populacionais e as densidades médias.

Além do que, a dignificação e o valor da vida humana (parâmetros a ter em devida conta em qualquer Estudo de Risco) têm hoje certamente uma outra dimensão.

Meios e dificuldades certamente bem acrescidas, quer no uso, quer na avaliação, quer na ponderação, quer ainda na acção. Bem como na transmissão da mensagem que encerram! Pelo que só a formação e a educação nestes domínios sensíveis e determinantes poderão trazer frutos a médio e longo prazo.

\section{Bịbliografia:}

É vasta e diversificada a Bibliografia com relevância para a Ordem de Cister, a Arquitectura e a Engenharia Cistercienses e o Mosteiro de Alcobaça. A relação que segue atende a alguns aspectos mais específicos do texto apresentado, sem que a omissão de tantas outras obras represente menor contributo para a causa em apreço. Causa que, como tudo o que respeita aos Cistercienses, só pode ser compreendida em análise global e abrangente e em cruzamento interdisciplinar.

AIRES-BARROS, Luis, As rochas dos monumentos portugueses tipologias e patologias (2 volumes), IPPAR 2001.

Arte e Arquitectura nas Abadias Cistercienses nos séculos XVI, XVII e XVIII, Colóquio 1994, Mosteiro de Alcobaça, IPPAR 2000.

BAPTISTA, J.Melo, A Água em Portugal como Bem Estratégico: a necessidade do seu uso mais eficiente, INGENIUM - Revista da Ordem dos Engenheiros, II Série $N^{\circ} 71$, Lisboa Nov./Dez. 2002.

BRONSEVAL, Frère Claude de, Peregrinatio Hispanica - Voyage de Dom Edme de Saulieu, Abbé de Clairvaux, en Espagne et au Poriugal 1531-1533 - Tome II, Centre Culturel Portugais da Fundação Caiouste Gulbenkian, Presses Universitaires de France, Paris 1970.

BROWN, A.G., Alluvial Geoarchaelogy - Floodplain Archaeology andenvironmental change, Cambridge University Press, $1997 /$ 2000.

C., F.A. de S., Memoria Historica ..., Typografia de Faria \& Silva, Porto 1840

Cister - Espaços, Territórios, Paisagens, Colóquio Internacional 1998 (2 volumes e 1 separata), Mosteiro de Alcobaça, IPPAR 2000.

Cisterno Vale do Douro, Grupo de Estudos de Histónia da Viticultura Duriense e do Vinho do Porto. Textos diversos, Edições Afrontamento, 1999.

COCHERIL, Dom Maur, com profusa produção sobre Alcobaça $c$ as Abadias Cistercienses em Portugal, Edições da Imprensa Nacional, 1989 (c/ a colaboração de J.M. Natividade Coelho), do Centro Cultural Português, Fundação Calouste Gulbenkian, Paris, 1971-76, e da ADEPA-Associação para a Defesa e Valorização do Património Cultural da Região de Alcobaça. 1983.

CORREIA, Vergílio - OBRAS - Volume V - Estudos Monográficos - Primeira Parte ALCOBAÇA - I - A Rainha D. Maria l em Alcobaça; II - Mudança dos túmulos reais de Alcobaça; $1 I I$ Uma descrição quinhentista do mosteiro de Alcobaça; IV Inscrições do Claustro do Silêncio, em Alcobaça; V - O retábulo da capela-mor de Alcobaça, Acta Universitatis Conimbrigensis, 1978.

DOBSON, WilliamT., A Narrative of the Peninsular Campaign 1807-1814, Bicker \& Son, London 1897. 
GIMPEL, Jean, La Révolution Industrielle du Moyen Age, Éditions du Seuil, 1975, estando esta obra traduzida para Português, $A$ Revolução Industrial da Idade Média, Publicações EuropaAmćrica, 2001.

GOMES, Saul A., Visitações a Mosteiros Cistercienses em Portugal-Séculos XV e XVI, IPPAR 1998.

GONÇALVES, Iria, O Património do Mosteiro de Alcobaça nos Séculos XIV e XV, Universidade Nova de Lisboa, Faculdade de Ciências Sociais e Humanas, Lisboa 1989.

JORGE, Virgolino Ferreira, Espaço e Euritmia na Abadia Medieval de Alcobaça, Separata do "Boletim Cultural" da Assembleia Distrital de Lisboa, Série IV-Nº 93, 1999.

KINDER, Terryl N., A Arqueologià da Água na Abadia Cisterciense de Fontfroide (Aude), em Hidráulica Monástica Medieval e Moderna, Fundação Oriente, Lisboa 1996 (Simpósio que decorreu no Convento da Arrábida Nov.1993, sob a Comissão Científica constituidapelos Professores Quintela, A.C., Arantes e Oliveira, E.R., Mascarenhas, J.M. e Jorge, V.F., e que contem diversos outros artigos de interesse).

KORRODI, Ernesto, Alcobaça - Estudo Historicó-Archeológico e Artístico da Real Abadia de Santa Maria de Alcobaça Monumentos de Portugal, Colecção de Vulgarisação ArtisticoMonumental sob o alto patrocinio da Associação dos Archeologos Potuguezes, No 4, Porto 1929.

LOPEZ, Robert S., The Commercial Revolution of the Middle Ages, 950-1350, Cambridge University Press, 1976, estando esta obra traduzida para Português, A Revolução Comercial da Idade Média 950-1350, Editorial Presença, 1986.

MADURO, António V., O Problema da Água na Serra dos Candeeiros, Alcobaciana $\mathrm{N}^{\circ} 5$, ADEPA-Associação para a Defesa e Valorização do Património Cultural da Região de Alcobaça, $199^{\circ} 7$.

MARQUES, Ma Alegria F., Estudos sobre a Ordem de Cister em Portugal, Faculdade de Letras da Universidade de Coimbra, Edições Colibri, 1998.

MARQUES, $M^{\mathrm{a}}$ Zulmira Furtado, com profusa produção sobre Alcobaça, oMosteiroe os Coutos, Edições diversas da Autora, Alcobaça 1992-2002.

MASCARENHAS, J.M. e Barbosa, P.G. e Jorge, Virgolino F., Les Cistercienset l'aménagement de l'espace. Le cas d'Alcobaça, in Pressouyre, Léon - "L'espace Cistercien" pág.s 153-164 Comité des Travaux Historiques et Scientifiques, Ministère de l’Enseignement Supérieur et de la Recherche, Paris 1994.

MOREIRA, Carlos Gil, Rossio de Alcobaça - Praça ou terra de ninguém. Revista "Oeste Cultural”, No 1, 2002.

NASCIMENTO, Aires A., Cister - Os Documentos Primitivos, Edições Colibri, Faculdade de Letras, Lisboa 1999.
NATIVIDADE, Manuel Vieira, Mosteiro e Coutos de AlcobaçaAlguns Capítulos extraídos dos manuscritos inéditosdo Autor e publicados no Centenário do seu Nascimento, Alcobaça 1960 , bem como diversas outras obras deste autor e de seu Filho, Eng ${ }^{\circ}$ Joaquim Vieira Natividade.

NATIVIDADE, Manuel Vieira, O Mosteiro de Alcobaça (Notas Históricas), Imprensa Progresso, Coimbra 1885.

PIMENTA, Alfredo, Os Historiógrafos de Alcobaça, Livraria Clássica Editora, Lisboa 1943.

REBELO, Fernando, Riscos Naturais e Acção Antrópica, Imprensa da Universidade de Coimbra, 2001.

RODRIGUES, Manuel F. e MENDES, J.M.Amado, História da Indústria Portuguesa - Da Idade Média soa nossos dias, Associação Industrial Portuense - Publicações EuropaAmérica, 1999.

ROSA, Luís Silva, A região de Cister no contexto geopolítico da história de Portugal, Separata de Cister-Espaços, Territórios, Paisagens, Colóquio Internacional 1998, Mosteiro de Alcobaça, IPPAR 2000.

SANTOS, Fr. Manoel dos, Alcobaça lllustrada-Noticias, e Historia dos Mosteyros, \& Monges insignes Cistercienses da Congregaçam de Santa Maria de Alcobaça da Ordem de S.Bernardonestes Reynos de Portugal, \& Algarves - Prymeira Parte, Officina de Bento Seco Ferreyra Impressor do Santo Officio, Coimbra 1710.

SANTOS, Fr. Manoel dos, Descrição do Rèal Mosteiro de Alcobaça, 1716 B.N.L. ALC. 307, FOLS. 1-35/ também em edição da ADEPA-Associação para a Defesa e Valorizaçãodo Património Cultural da Região de Alcobaça, com Leitura, Introdução e Notas de Aires Augusto Nascimento, ALCOBACIANA 3. 1979.

TAVARES, J.Pedro D., Sistema Hidráulico Cisterciense, capítulo do Roteiro Cultural de Alcobaça - A Oeste da Serra dos Candeeiros, Edição conjunta da C.M.Alcobaça e da ADEPA, sob a coordenação de Mendonça da Silva, Carlos / Temas e Autores diversos, Alcobaça 2001.

VILLA NOVA, Bernardo, Alcobaça através do Arquivo da sua Câmara Municipal (1836-1902), Edição da C.M.Alcobaça, 1940, tendo este autor publicado inúmeras outras obras de relevante interesse, nomeadamente $O$ Progresso Urbano $d a$ Vila de Alcobaça (Algumas outras notas), Imprensa Lucas \& $\mathrm{C}^{\mathrm{a}}$, Lisboa 1941 e Mais Subsídios para a Histórioa de Alcobaça, Tipografia Alcobacense $\mathrm{Ld}^{\mathrm{a}}, 1962$.

ZBYSZEWSKi, G e FRANÇA, J. Camarate, Carta Geológica de Portugal - Notícia Explicativa da Folha 26-B Alcobaça, Serviços Geológicos de Portugal, Lisboa 1963.

ZIEGLER, Philip, The Black Death, The Folio Society, London, 1997. 